\title{
UM ESTUDO SOBRE A DESCONEXÃO ENTRE USUÁRIOS E DESENVOLVEDORES DE SISTEMAS DE INFORMAÇÃO E SUA INFLUÊNCIA NA OBTENÇÃO DE INFORMAÇÃO PELO DECISOR
}

\section{Samuel Stábile}

Dissertação apresentada à Escola de Engenharia de São Carlos da Universidade de São Paulo, como parte dos requisitos para obtenção do título de Mestre em Engenharia de Produção

ORIENTADOR:

Prof. Dr. Edson Walmir Cazarini

São Carlos

2001 
Aos meus pais, eternos professores. À Andréia, companheira constante. 
Ao Professor Dr. Edson Walmir Cazarini, pela orientação e amizade no decorrer do trabalho.

A todos os colegas, professores e funcionários da Engenharia de Produção.

Aos funcionários da Biblioteca da EESC.

Aos amigos do Yázigi Internexus - Birigui - SP. 


\section{SUMÁRIO}

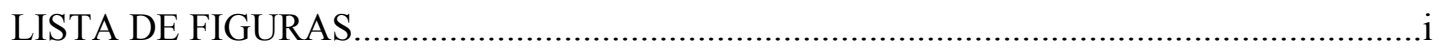

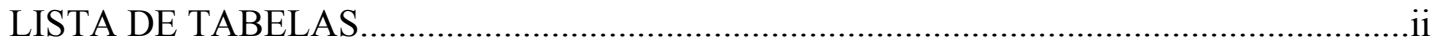

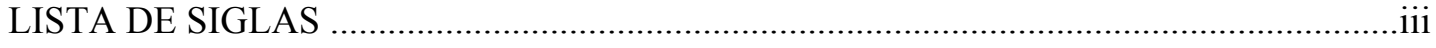

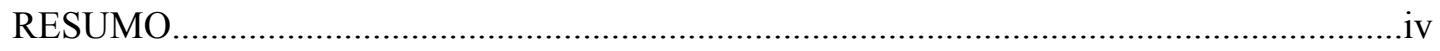

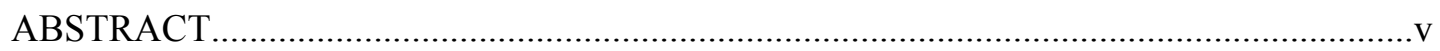

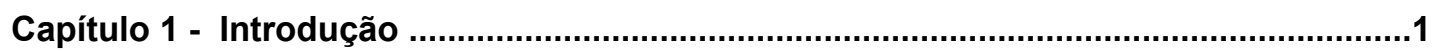

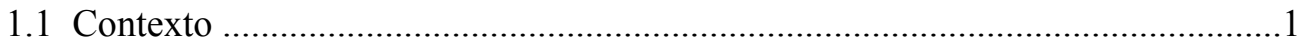

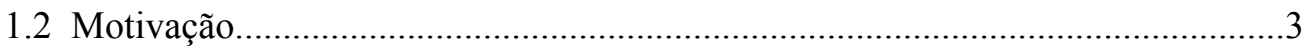

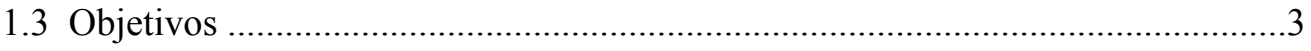

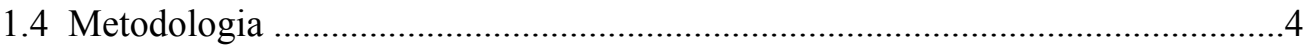

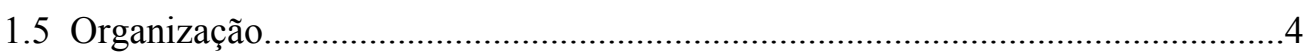

Capítulo 2 - O trabalho administrativo..............................................................................6

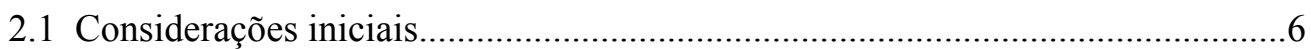

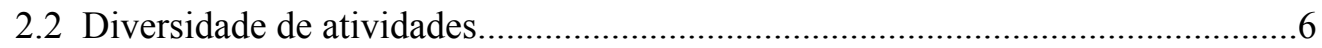

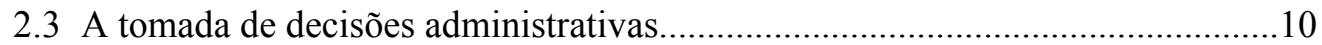

2.3.1 Problemas estruturados e não estruturados......................................11

2.3.2 Elementos do processo decisorial.................................................12

2.3.3 Etapas do processo decisorial..........................................................13

2.3.4 Decisões programadas e não programadas........................................16

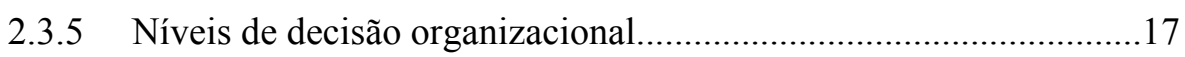

2.3.6 Condições de decisão..................................................................18

2.3.7 A decisão no ambiente organizacional..............................................19

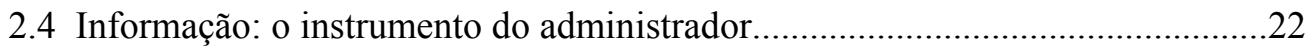

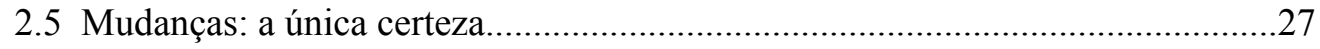

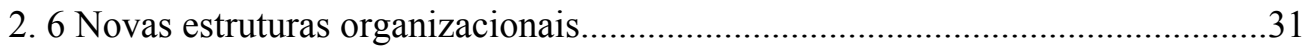

2.7 Considerações finais do capítulo 2 ....................................................................

Capítulo 3 - Qualidade da informação........................................................................43

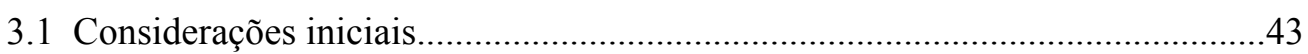

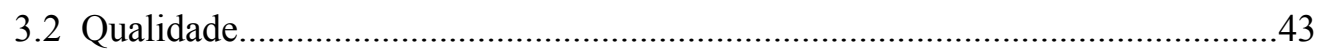

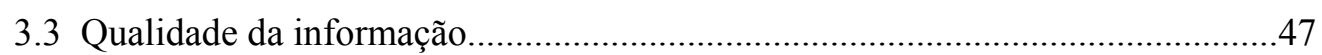

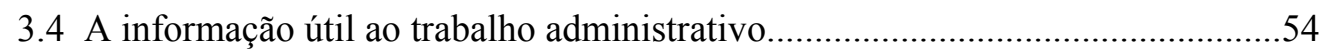

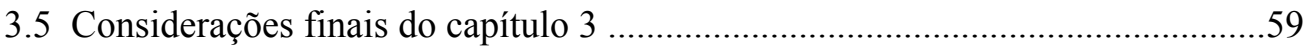


Capítulo 4 - A desconexão entre usuários e desenvolvedores .61

4.1 Considerações iniciais 61

4.2 A tecnologia da informação nas organizações .61

4.3 A desconexão entre usuários e desenvolvedores ...............................................72

4.4 Enfoque operacional dos sistemas de informação .................................................79

4.5 Enfoque tecnológico dos sistemas de informação .................................................

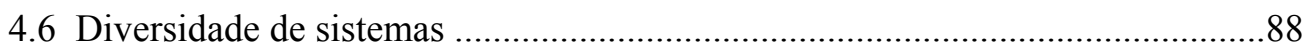

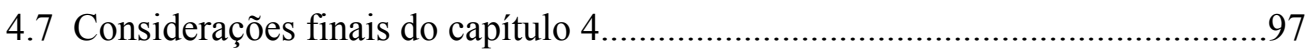

Capítulo 5 - Como a desconexão afeta a obtenção de informação pelo decisor................98

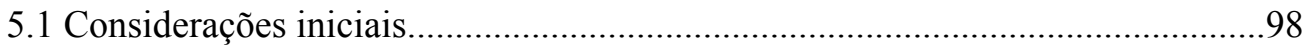

5.2 Enfoque operacional dos sistemas de informação ...............................................98

5.3 Enfoque tecnológico dos sistema de informação ...............................................103

5.4 Diversidade de sistemas ...................................................................................104

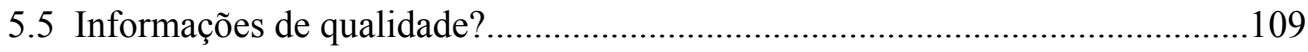

5.6 Considerações finais do capítulo 5..............................................................111

Capítulo 6 - Aspectos de aproximação entre usuários e desenvolvedores ...............112

6.1 Considerações iniciais..................................................................................112

6.2 O perfil do profissional de informática ..........................................................112

6.3 Aspectos humanos nas implementações.............................................................113

6.4 Integração dos sistemas ..............................................................................115

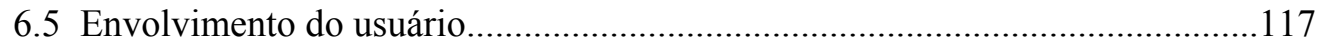

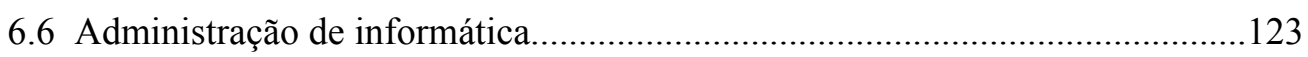

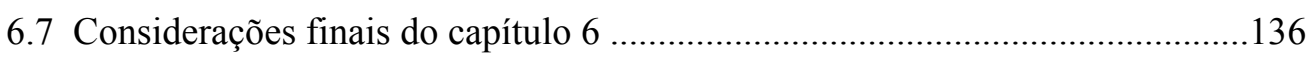

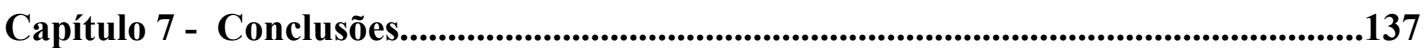

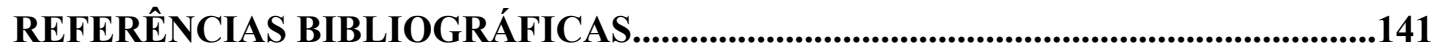




\section{LISTA DE FIGURAS}

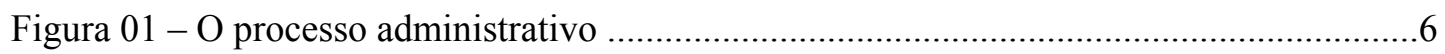

Figura 02 - Detalhamento das funções do administrador .......................................................

Figura 03 - Decisões sobre objetivos e recursos...............................................................

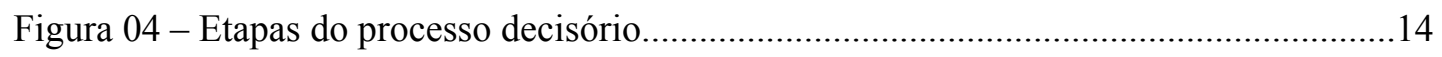

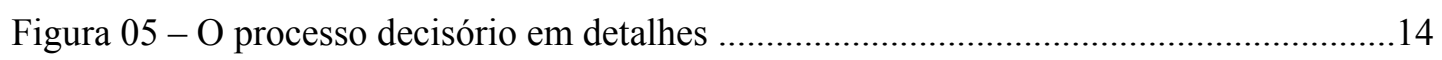

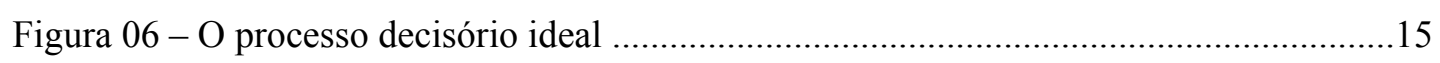

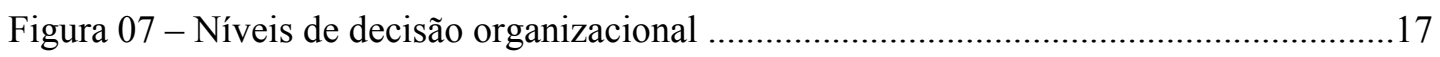

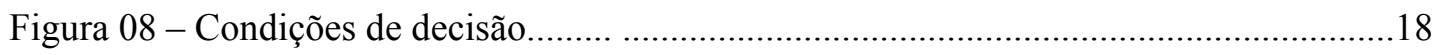

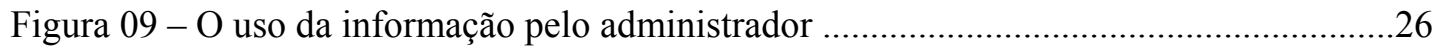

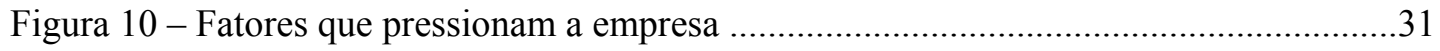

Figura 11 - Ciclo objetivado pela Ciência da Informação …………………………..............51

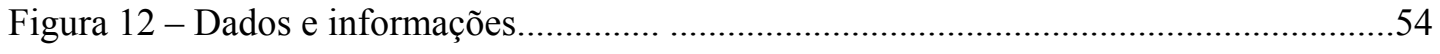

Figura 13 - Redução de incerteza causada pela informação ..................................................55

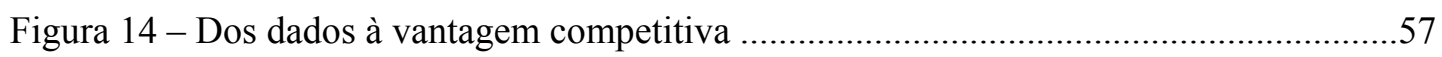

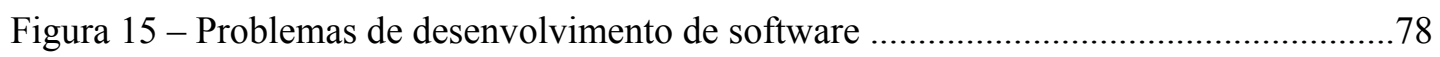

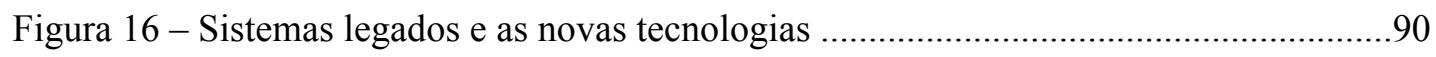

Figura 17 - Foco operacional dos sistemas e a atuação estratégica dos administradores.....102

Figura 18 - A organização vista como um fluxo único de informação .................................109

Figura 19 - Distribuição dos investimentos em relacionamento com clientes .....................133

Figura 20 - Distribuição ideal dos investimentos em relacionamento com clientes .............134

Figura 21 - Posicionamento ideal da informática nas empresas ...........................................136 


\section{LISTA DE TABELAS}

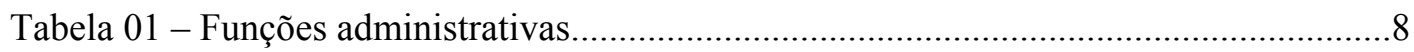

Tabela 02 - Características das decisões programadas e não programadas............................16

Tabela 03 - Problemas estruturados e não estruturados e as decisões programadas e

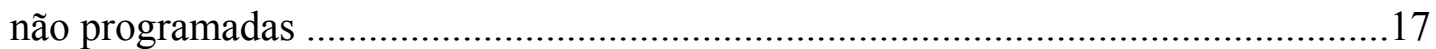

Tabela 04 - Racionalidade perfeita e racionalidade limitada das decisões............................20

Tabela 05 - Características tradicionais e características do século XX ...............................36

Tabela 06 - Organizações departamentais e organizações orientadas para processos............38

Tabela 07 - Dimensões-chave das abordagens centralizada e descentralizada........................39

Tabela 08 - Sistemas mecanicistas e sistemas orgânicos...........................................................40

Tabela 09 - As três eras da administração do século XX .........................................................

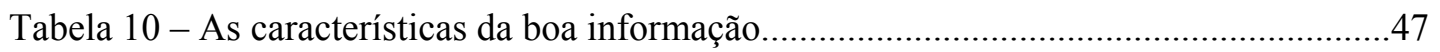

Tabela 11 - Oito dimensões da qualidade da informação.......................................................49

Tabela 12 - Quatro categorias dos aspectos usuais da qualidade da informação ...................49

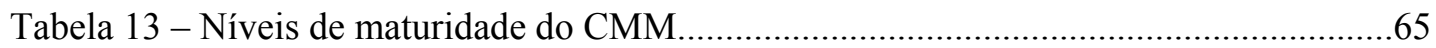

Tabela 14 - Distribuição das organizações nos níveis do CMM .............................................66

Tabela 15 - Custo relativo de reparação de erros.....................................................................77

Tabela 16 - Dados operacionais e dados analíticos ...........................................................102

Tabela 17 - Problemas e consequências da geração de informação para o administrador...110 


\section{LISTA DE SIGLAS}

$\begin{array}{ll}\text { ANGRAD } & \text { - Associação Nacional dos Cursos de Graduação em Administração } \\ \text { ANSI } & \text { - American National Standard Institute } \\ \text { ASQC } & \text { - American Society for Quality Control } \\ \text { CEO } & \text { - Chief Executive Officer } \\ \text { CIO } & \text { - Chief Information Officer } \\ \text { CITEC } & \text { - Centro de Informação Tecnológica } \\ \text { CMM } & \text { - Capability Maturity Model } \\ \text { CMU } & \text { - Carnegie Mellon University } \\ \text { CPFL } & \text { - Companhia Paulista de Força e Luz } \\ \text { E-Business } & \text { - Comércio Eletrônico } \\ \text { EMBRAPA } & \text { - Empresa Brasileira de Pesquisa Agropecuária } \\ \text { ERP } & \text { - Enterprise Resource Planning } \\ \text { FASB } & \text { - Financial Accounting Standards Board } \\ \text { HP } & \text { - Hewlett Packard } \\ \text { IBM } & \text { - International Business Machine } \\ \text { IPT } & \text { - Instituto de Pesquisa Tecnológicas } \\ \text { ONG } & \text { - Organização não governamental } \\ \text { PRODAM } & \text { - Companhia de Processamento de Dados do Município de São Paulo } \\ \text { SABESP } & \text { - Companhia de Saneamento Básico do Estado de São Paulo } \\ \text { SEI } & \text { - Software Engineering Institute } \\ \text { TI } & \text { - Tecnologia da informação }\end{array}$




\section{RESUMO}

STÁBILE, S. (2001) Um estudo sobre a desconexão entre desenvolvedores e usuários de sistemas de informação e sua influência na obtenção de informação pelo decisor organizacional. São Carlos, 2001. 153p. Dissertação (Mestrado) - Escola de Engenharia de São Carlos , Universidade de São Paulo.

As organizações encontram-se em um ambiente de acirrada e crescente concorrência, exigindo delas rapidez, flexibilidade e alta percepção. As decisões tomadas pelos administradores tornam-se mais importantes e freqüentes, devendo combinar velocidade e embasamento. Assim, a atuação destes profissionais, torna-se mais crítica e importante para o desempenho das organizações. Para atuarem satisfatoriamente neste contexto competitivo, os administradores necessitam ter disponível seu principal instrumento: a informação. Com este objetivo, muitos recursos são investidos em sistemas de informação, mas nem sempre os resultados esperados são alcançados. Este trabalho aborda a desconexão entre desenvolvedores e usuários de sistemas de informação, como problema nas organizações; investiga como esta desconexão afeta a obtenção de informação pelos decisores e apresenta formas de aproximação entre desenvolvedores e usuários, visando melhorias no uso de sistemas de informação.

Palavras-chave: trabalho administrativo, decisão, sistema de informação, informação, desconexão, usuários, desenvolvedores. 


\begin{abstract}
STÁBILE, S. (2001). A study of the disconnection between developers and users of information systems and its influence on obtaining information by the organizational decision maker. São Carlos, 2001. 153p. Dissertação (Mestrado) - Escola de Engenharia de São Carlos , Universidade de São Paulo.

Organizations meet in an environment of hard and growing competition, demanding from them, speed, flexibility and high perception. Decisions taken by the administrators become more frequent and important, and they should combine speed and foundation. Thus, these professionals' work, becomes more critic and important to the performance of organizations. In order to act satisfactorily in this competitive context, these administrators need to have available their main instrument: information. With this objective, many resources are invested in information systems, however, the expected results are not always reached. This work approaches the disconnection between developers and users of information systems, as a problem in organizations; it investigates how this disconnetion affects the obtainment of information by the decision makers and it presents approaching ways between developers and users, seeking improvements in the use of information systems.
\end{abstract}

Keywords: administrative work, decision, information system, information, disconnection, users, developers. 


\section{Capítulo 1 - Introdução}

\subsection{Contexto}

A informação é sem dúvida, o recurso mais importante das organizações na era da informação. Autores como STEWART (1998) e CHIAVENATTO (2000b) afirmam que o valor das organizações está se acumulando nas informações, e, não mais, em dinheiro ou em bens físicos. Vários outros autores como CAVALCANTI (1995), ROBIC \& SBRAGIA (1996), GOLDBACH (1998), XAVIER \& GOMES (1999), VAZ (1999), CALDAS \& WOOD (2000), abordam a importância da informação para o gerenciamento das organizações. A competitividade, cada vez mais acirrada e presente no dia a dia das organizações, requer que estas sejam rápidas e flexíveis para que obtenham sucesso, e o satisfatório uso da informação, torna-se essencial.

As organizações são dependentes da atuação de seus dirigentes. Executivos, administradores e gerentes vêem seu trabalho ganhar mais e mais importância pois, se as organizações sempre dependeram de seus trabalhos, agora, com maior competitividade, estes trabalhos tornam-se mais críticos. McCARTHY (1994) afirma que todos os anos, milhares de organizações fracassam porque seus administradores falham. NUTT (1998), em uma pesquisa realizada com executivos de organizações de grande e médio porte, comprovou que, cerca da metade das decisões tomadas pelos seus dirigentes, fracassou. CHIAVENATO (2000a), afirma que a tomada de decisões é o núcleo da responsabilidade administrativa. O administrador deve constantemente decidir o que fazer, quem deve fazer, quando, onde e, muitas vezes, como fazer. BISPO \& CAZARINI (1998), colocam que a função dos administradores na organizações é extremamente decisória, e que os processos administrativos são basicamente processos decisórios.

McKENNA (2000), ao abordar o atual ambiente concorrencial das organizações, afirma que as mudanças no comportamento do consumidor, as estratégias competitivas e a inexorável força das novas tecnologias estão influenciando simultaneamente as organizações. Os processos são cada vez mais complexos, com um número muito maior do que antes de fatores que influenciam a tomada de decisão. BISPO \& CAZARINI (1998), compartilham desta afirmação colocando que hoje existem mais fatores que influenciam o processo de tomada de decisão do que antes.

GLAUTIER \& UNDERDOWN, apud BEUREN (1998), afirmam que, no processo de tomada de decisão, uma das etapas é coletar todas as informações relevantes para as alternativas de solução. Portanto, é essencial que os gestores disponham das informações desejadas no momento desejado. Segundo CHIAVENATO (2000a), as empresas procuram 
proporcionar às pessoas, que tomam suas decisões, todas as informações de que necessitam e em tempo hábil, para que sejam bem sucedidas nas escolhas. BISPO \& CAZARINI (1998), afirmam que a quantidade de informações a respeito da situação, constitui um fator de extrema importância para o processo decisório. Quanto mais informações forem levantadas a respeito da mesma, evidentemente, melhor será a sua compreensão e a sua solução.

Sendo a informação o instrumento específico do administrador, e uma vez que esta assume cada vez mais importância para as organizações, neste novo panorama competitivo, quanto melhor a organização gerenciar suas informações, maiores serão as chances de sucesso no mercado. Assim, as organizações utilizam sistemas de informação para gerenciarem suas informações e lutarem com mais chances pelos seus objetivos. VAZ (1999), diante do valor fundamental que a informação possui para a administração, no atual cenário concorrencial, coloca que a tecnologia da informação passa a ser importantíssima para agilizar a aquisição, o processamento e a divulgação da informação dentro das organizações, possibilitando a estas a busca por lucros e resultados satisfatórios.

Deve ser observado, entretanto, que não existe uma relação direta entre os investimentos em tecnologia da informação e o retorno em competitividade e produtividade. McGEE \& PRUSAK (1994), ROBIC \& SBRAGIA (1996), BENSAOU \& EARL (1998), BELLOQUIM (1999c), TAURION (2000), CALDAS \& WOOD (2000), STÁBILE \& CAZARINI (2000b) abordam este problema colocando que, dirigentes e executivos reclamam constantemente dos altos investimentos realizados em tecnologia de informação e a falta de resultados precisos em produtividade e competitividade. BENSAOU \& EARL (1998), observam que embora que muitos executivos reconheçam a importância da tecnologia da informação, suas experiências usando-a como ferramenta estratégica de negócio é freqüentemente frustrante. Como problemas apontados pelos executivos, os autores listam:

- os investimentos em tecnologia da informação não são relacionados com a estratégia de negócios;

- o retorno financeiro dos investimentos em tecnologia da informação é inadequado;

- a tecnologia é empregada cegamente, sem objetivos definidos;

- as relações entre usuários e especialistas não é boa;

- os projetistas de sistemas não consideram as preferências e os hábitos de trabalho dos usuários.

Nesta mesma linha, WANG (1995), observa que existe uma total desconexão entre a área de sistemas e os executivos das organizações. O autor explica que existe um 
desconhecimento total do que o outro lado fala, e acusações são constantes. SAVIANI (1998), também aborda o relacionamento ruim que se observa nas organizações, entre a área de tecnologia da informação e as demais áreas. EARL \& FEENY (2000), colocam a tecnologia da informação como questão de sobrevivência para as organizações, mas afirmam que, infelizmente, muitos dos profissionais, que estão na direção das empresas, não se mostram bem preparados para lidar com este assunto.

\subsection{Motivação}

Conscientes da importância da informação, no atual cenário competitivo, as organizações buscam seu satisfatório gerenciamento, a fim de utilizá-la estrategicamente. Se os administradores, profissionais que dirigem as organizações, tiverem acesso às informações desejadas, tomarão melhores decisões de negócio. Muitos recursos são investidos em sistemas de informação, visando oferecer às pessoas da organização, tais informações. Porém, é sabido que grande parte das organizações, mesmo com grandes investimentos em sistemas de informação, tem problemas quanto ao gerenciamento de suas informações, dificultando em muito o processo de tomada de decisão - centro do trabalho dos administradores. BEUREN (1998), afirma que deve haver uma integração entre os modelos de decisão e as informações disponibilizadas, através da integração entre o sistema de informação e o sistema organizacional, e com o alinhamento das estratégias de negócio com a tecnologia da informação. Dessa forma, assume grande importância uma investigação sobre como a desconexão entre usuários e desenvolvedores de sistemas de informação afeta a obtenção de informação pelos decisores nas organizações.

\subsection{Objetivos}

No contexto exposto, ressaltam-se os seguintes pontos:

- a tomada de decisão é o centro do trabalho administrativo;

- no atual ambiente organizacional, os administradores são obrigados a tomarem decisões com maior constância e embasamento;

- a informação é o insumo básico dos administradores nos processos de tomada de decisão;

- as organizações investem em sistemas de informações para melhor gerenciarem suas informações;

- muitas organizações apresentam problemas no uso de seus sistemas de informação; 
- a desconexão entre usuários e desenvolvedores de sistemas de informação é um problema presente em muitas organizações.

Assim, este trabalho tem como objetivo geral, apresentar uma investigação, sobre como a desconexão entre usuários e desenvolvedores de sistemas de informação, afeta a obtenção de informação pelo decisor organizacional, e como melhorar a relação entre os dois grupos de profissionais.

Como objetivos específicos, têm-se:

- Investigar como se configura o trabalho administrativo no atual ambiente concorrencial, e qual o papel da informação neste trabalho;

- Investigar a desconexão entre usuários e desenvolvedores de sistemas de informação nas organizações;

- Disponibilizar conhecimento às organizações, contribuindo para a competitividade das mesmas;

- Disponibilizar conhecimento aos demais mestrandos que trabalham em assuntos correlatos.

\subsection{Metodologia}

Pesquisa realizada através de revisão bibliográfica. Segundo GIL (1991), esta pesquisa é desenvolvida a partir de material já elaborado, constituído principalmente de livros e artigos científicos. CERVO \& BERVIAN (1996), descrevem a pesquisa bibliográfica como aquela que procura explicar um problema a partir de referências teóricas publicadas em documentos. Como principal vantagem da pesquisa bibliográfica, GIL (1991) afirma que esta reside no fato de permitir ao investigador a cobertura de uma gama de fenômenos muito mais ampla do que aquela que se teria com a pesquisa direta.

\subsection{Organização}

Trabalho organizado em 7 capítulos, da seguinte maneira:

Neste capítulo, o assunto é contextualizado; são apresentados os objetivos e a motivação pela escolha do tema.

No Capítulo 2, é exposto como se configura o trabalho administrativo no atual panorama competitivo.

No Capítulo 3, é abordada a importância da informação para os administradores e suas características qualitativas.

No Capítulo 4, é exposto o uso dos sistemas de informação nas organizações, bem como a desconexão entre a área de informática e as áreas usuárias. 
No Capítulo 5, é apresentada uma investigação, de como a desconexão entre usuários e desenvolvedores, afeta a obtenção de informação pelo decisor administrativo.

No Capítulo 6, são apresentados vários aspectos a serem focados na aproximação entre usuários e desenvolvedores de sistemas de informação, visando o melhor uso destes sistemas nas organizações.

No Capítulo 7, as conclusões são apresentadas. 


\section{Capítulo 2 - 0 trabalho administrativo}

\subsection{Considerações iniciais}

Neste capítulo é descrita a atuação dos administradores nas organizações, contextualizada no novo panorama competitivo, mostrando que o administrador não possui uma rotina fixa de trabalho, e lida com problemas não estruturados e variados, por estar constantemente respondendo a estímulos. É exposto que o trabalho administrativo é basicamente decisório, que o administrador necessita de informações para estas decisões, e que novas formas de estruturas organizacionais estão surgindo visando decisões mais rápidas e eficientes.

\subsection{Diversidade de atividades}

De acordo com CHIAVENATO (2000a), a tarefa do administrador é interpretar os objetivos da empresa e transformá-los em ação empresarial, através de planejamento, organização, direção e controle de todos os esforços realizados em todas as áreas e em todos os níveis da empresa, a fim de atingir tais objetivos. Então, a administração é o processo de planejar, organizar, dirigir e controlar a aplicação dos recursos organizacionais, para alcançar determinados objetivos de maneira eficiente e eficaz.

Segundo CHIAVENATO (2000b), o processo administrativo pode ser representado de acordo com a figura 1:

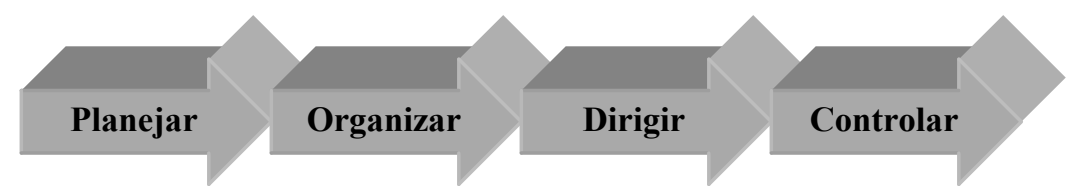

Figura 1 - O processo administrativo - CHIAVENATTO (2000b)

O autor afirma que o processo administrativo é mais do que uma seqüência cíclica, pois existe um forte relacionamento entre as etapas, tornando-o interativo e dinâmico. A figura 2 detalha as funções do administrador, constituintes do processo administrativo: 


\begin{tabular}{|c|c|c|c|}
\hline Planejamento & Organização & Direção & Controle \\
\hline $\begin{array}{l}\text { - definir missão } \\
\text { - formular } \\
\text { objetivos } \\
\text { - definir os planos } \\
\text { para alcançá-los } \\
\text { - programar as } \\
\text { atividades }\end{array}$ & $\begin{array}{l}\text { - dividir o } \\
\text { trabalho } \\
\text { - designar as } \\
\text { atividades } \\
\text { - agrupar as } \\
\text { atividades em } \\
\text { órgãos e cargos } \\
\text { - alocar recursos } \\
\text { - definir } \\
\text { autoridade }\end{array}$ & $\begin{array}{l}\text { - designar } \\
\text { as pessoas } \\
\text { - coordenar } \\
\text { os esforços } \\
\text { - comunicar } \\
\text { - motivar } \\
\text { - liderar } \\
\text { - orientar }\end{array}$ & $\begin{array}{l}\text { - definir padrões } \\
\text { - monitorar } \\
\text { o desempenho } \\
\text { - avaliar } \\
\text { o desempenho } \\
\text { - ação corretiva }\end{array}$ \\
\hline
\end{tabular}

Figura 2 - Detalhamento das funções do administrador

CHIAVENATTO (2000b) define as quatro funções administrativas da seguinte forma:

- planejamento - figura como a primeira função, pois serve de base para as demais. É a função administrativa que define antecipadamente quais são os objetivos que devem ser atingidos e como fazer para atingi-los. É um modelo teórico para a ação futura. Começa com a determinação dos objetivos e detalha os planos necessários para alcançá-los da melhor maneira possível. Planejar é definir objetivos e escolher, antecipadamente, o melhor curso de ação para alcançá-los. Esta função define onde a empresa quer chegar, o que deve ser feito, quando, como e em que seqüência.

- organização - ato de organizar, estruturar e integrar os recursos e os órgãos incumbidos da administração e estabelecer as relações entre eles e as atribuições de cada um. Para que os objetivos definidos no planejamento possam ser alcançados, os planos executados, e as pessoas trabalharem eficientemente, as atividades precisam ser agrupadas de maneira lógica e a autoridade distribuída de maneira a se evitarem conflitos. A organização consiste em:

- determinar as atividades específicas necessárias ao alcance dos objetivos planejados (especialização);

- agrupar as atividades em uma estrutura lógica (departamentalização);

- designar as atividades às específicas posições e pessoas (cargos e tarefas);

- direção - após a definição do planejamento e do estabelecimento da organização, a direção é a função administrativa que faz as coisas acontecerem, ou seja, ela dinamiza e aciona a empresa. A direção está muito relacionada com a ação e com a atuação sobre os recursos humanos da empresa. As pessoas precisam ser aplicadas em seus cargos e funções, treinadas e motivadas para 
atingirem os objetivos delas esperados. A direção é a função administrativa que se refere às relações interpessoais dos administradores em todos os níveis da organização com seus respectivos subordinados.

- controle - função administrativa que tem como objetivo assegurar que os resultados do que foi planejado, organizado e dirigido sejam alcançados. A essência do controle é a comparação dos resultados obtidos com os resultados planejados. Através desta comparação, eventuais medidas corretivas são tomadas, visando assegurar o desempenho desejado.

MAXIMIANO (2000) define administração como o processo ou atividade dinâmica, que consiste em tomar decisões sobre objetivos e recursos, conforme mostra a figura 3:
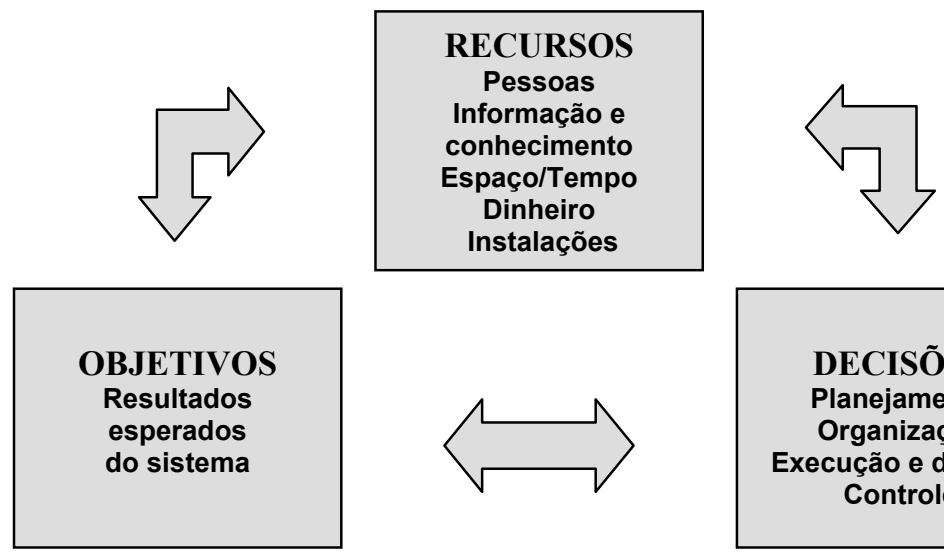

Figura 3 - Decisões sobre objetivos e recursos - MAXIMIANO (2000)

$\mathrm{O}$ autor afirma que tomar decisões significa fazer escolhas, e que o processo administrativo abrange quatro tipos principais de decisões, também chamadas de processos ou funções. Na tabela 1 é apresentado um resumo dos quatro processos, de acordo com MAXIMIANO (2000):

Tabela 1 - Funções administrativas - MAXIMIANO (2000)

\begin{tabular}{|l|l|}
\hline \multicolumn{1}{|c|}{ Processo } & \multicolumn{1}{|c|}{ Significado } \\
\hline Planejamento & $\begin{array}{l}\text { Consiste em tomar decisões sobre objetivos e recursos necessários para } \\
\text { realizá-los }\end{array}$ \\
\hline Organização & $\begin{array}{l}\text { Consiste em tomar decisões sobre a divisão de autoridade e } \\
\text { responsabilidade entre pessoas e sobre a divisão de recursos para realizar } \\
\text { as tarefas e objetivos }\end{array}$ \\
\hline Direção & $\begin{array}{l}\text { Compreende as decisões que acionam recursos, especialmente pessoas, } \\
\text { para realizar tarefas e alcançar objetivos. }\end{array}$ \\
\hline Controle & $\begin{array}{l}\text { Consiste em tomar decisões e agir para assegurar a realização dos } \\
\text { objetivos. }\end{array}$ \\
\hline
\end{tabular}


De acordo com CHIAVENATTO (2000b), o planejamento, a organização, a direção e o controle, de um modo geral, são aceitas como as quatro funções básicas do administrador, e constituem o chamado processo administrativo. MINTZBERG (1986), MAXIMIANO (2000), ROBBINS \& COULTER (1998) e ROBBINS (2000) também afirmam que o conjunto destas quatro atividades é a descrição mais encontrada sobre o trabalho administrativo.

Porém, vários autores contestam esta descrição mais aceita e encontrada sobre o trabalho administrativo. KOTTER (1982), afirma que existe grande distância entre a descrição mais aceita sobre o trabalho dos gerentes e a verdadeira rotina observada na vida destes profissionais. $\mathrm{O}$ autor enumera como problemas dos administradores, as incertezas e a grande diversidade de atividades, e continua, colocando que estes problemas são muito sérios e dificultam enormemente suas tarefas básicas, concluindo que, o comportamento destes profissionais é quase sempre difícil de se caracterizar.

MINTZBERG (1986), afirma que as quatro funções básicas constituem a descrição mais antiga e também a mais encontrada sobre o trabalho administrativo. Porém, segundo o mesmo autor, ao observar as atividades desenvolvidas pelos administradores, não devemos nos surpreender se não conseguirmos relacionar seu trabalho com as quatro funções listadas. O mesmo autor acrescenta que um grande número de estudos mostra que os administradores trabalham em um ritmo inexorável, e que suas atividades se caracterizam pela brevidade, variedade e descontinuidade, e que eles são firmemente orientados para a ação, não apresentando inclinações para atividades de reflexão. Segundo o autor, nenhum estudo constatou a existência de padrões definitivos na maneira como os administradores organizam seu tempo. Eles parecem muito mais ocupados com problemas, respondendo continuamente às solicitações do momento. $\mathrm{O}$ administrador simplesmente responde às pressões de seu trabalho e aos estímulos temporais.

De acordo com MINTZBERG (1995), as atividades nos níveis mais altos das organizações apresentam um mínimo de repetições e de padronizações. O trabalho dos administradores é tipicamente, o menos especializado da organização, pois os papéis desempenhados por eles são muito variados e muitas mudanças são exigidas deles durante o decorrer de um único dia. Assim, estes profissionais não reclamam de tédio ou repetição no trabalho, mas sim da falta de oportunidade para se concentrar em resultados específicos. Por este motivo, observam-se tentativas de redesenhar o serviço do executivo principal dirigido para a especialização, e não para a ampliação. Mesmo assim, o trabalho deste profissional parece continuar tão ampliado como nunca, e os administradores da alta cúpula apresentam 
grande descontinuidade em seu trabalho. LUCAS (1997), neste mesmo sentido, afirma que os gerentes lidam com as exceções organizacionais.

ROBBINS \& COULTER (1998) afirmam que o estudo de Mintzberg desafiou idéias antigas e estabelecidas que pregavam ser o administrador um pensador reflexivo que procurava informações, cuidadosamente e sistematicamente, antes de tomar decisões. $\mathrm{O}$ estudo provou que o administrador se lança em um grande número de atividades variadas, não padronizadas e de curta duração, sem tempo para reflexão por sofrer constantes interrupções.

Dessa forma, verificamos que o administrador não possui uma rotina de trabalho definida, por estar constantemente respondendo à estímulos. E, no atual ambiente competitivo, estes estímulos são mais constantes. Por não possuírem uma rotina de trabalho definida, as situações enfrentadas pelos administradores são breves, variáveis e descontínuas. Assim, conclui-se que, para cada situação, informações diferentes são necessárias, ou seja, a natureza do trabalho administrativo impõe a este profissional, necessidades informacionais variáveis, em contraste com os demais profissionais dos níveis inferiores das organizações, que por lidarem com rotinas mais estáveis e problemas mais repetitivos, apresentam uma tendência de possuírem necessidades informacionais mais definidas e estáveis.

Ainda evidenciando a diversidade de atividades dos administradores, BAKER et al. (1998), colocam que estes profissionais defrontam-se freqüentemente com situações de decisões não estruturadas e complexas, necessitando fazer escolhas com base limitada de informação e problemas não muito claros. Assim, os tomadores de decisão não tem como escolher a alternativa ótima.

\subsection{A tomada de decisões administrativas}

MINTZBERG (1995), ROBBINS \& COULTER (1998), SEELEY \& TARGETT (1999), BISPO \& CAZARINI (1998), MAXIMIANO (2000), CHIAVENATTO (2000a) e ROBBINS (2000), afirmam que a tarefa de tomar decisões faz parte do trabalho de qualquer administrador. MAXIMIANO (2000) define a administração como um processo ou atividade dinâmica, que consiste em tomar decisões sobre objetivos e recursos. MINTZBERG (1995), como uma das partes básicas da organização, apresenta a chamada cúpula estratégica, onde trabalharam as pessoas de mais alto nível, com responsabilidade total pela organização, e que tomam as decisões mais importantes. As pessoas da cúpula são responsáveis pela interação da organização com o meio ambiente, no qual ela se encontra inserida, e respondem às pressões do meio externo através de várias decisões. De modo geral, a cúpula estratégica tem a visão mais ampla e abstrata da organização. O trabalho neste nível apresenta um mínimo 
de repetições e de padronizações e os profissionais são submetidos a longos ciclos para tomada de decisão. Segundo CHIAVENATO (2000a), a tomada de decisões é o núcleo da responsabilidade administrativa, e o administrador deve constantemente decidir sobre situações na organização. $\mathrm{O}$ autor define o ato de decidir como optar ou selecionar, dentre várias alternativas de cursos de ação, por aquela que pareça mais adequada. Afirma, ainda, que as decisões são tomadas em resposta a algum problema a ser resolvido, a alguma necessidade a ser satisfeita ou a algum objetivo a ser alcançado. ROBBINS \& COULTER (1998) afirmam que a importância da tomada de decisão é enorme em todas os aspectos do trabalho do administrador e que tomar decisões é sinônimo de administrar. SEELEY \& TARGETT (1999) afirmam que tomar decisões é um dos papéis dos administradores nas empresas. ROBBINS (2000) coloca que, quase tudo que os gerentes fazem, implica em tomar decisões, e muitos analistas afirmam que este é o cerne do trabalho administrativo. BISPO \& CAZARINI (1998), colocam que a função dos administradores na organizações é extremamente decisória, e que os processos administrativos são basicamente processos decisórios. Os autores afirmam, que uma decisão precisa ser tomada sempre que o administrador está diante de um problema que apresenta mais de uma alternativa para a sua solução. Mesmo para solucionar um problema onde se tem uma única ação a tomar, existem as alternativas de tomar ou não esta ação.

MINTZBERG (1986) afirma que uma coisa ficou bem clara em seus estudos sobre o trabalho administrativo: o executivo desempenha o principal papel no sistema decisorial de sua unidade, pois sendo seu centro nervoso, só a ele compete tomar as decisões de sua unidade. DRUCKER (1996), a respeito do processo decisório, presente no trabalho administrativo, afirma que os executivos têm que tomar decisões que comprometem para o futuro, recursos correntes de tempo e dinheiro, e que outras decisões piores seriam as decisões de não comprometer recursos - de desistir do futuro. WANCELOTTI \& LOMBOGLIA (2000) afirmam que a vantagem competitiva de uma empresa, passa a depender ainda mais de sua capacidade de tomadas de decisões certas e rápidas, e de sua estratégia de gestão do conhecimento acumulado de seus produtos, serviços, clientes e concorrentes.

\subsubsection{Problemas estruturados e não estruturados}

CHIAVENATTO (2000b) afirma que o administrador lida com problemas, e define problema como uma discrepância entre o que é, (a realidade), e o que poderia ou deveria ser (valores, metas, objetivos). Segundo o autor, a organização defronta-se com uma variedade 
de problemas, em diferentes graus de complexidade, que podem ser classificados em estruturados e não estruturados.

- problema estruturado - é aquele que pode ser perfeitamente definido, pois suas principais variáveis - como os estados da natureza, ações e conseqüências possíveis - são conhecidas;

- problema não estruturado - aquele que não pode ser claramente definido, pois uma ou mais de suas variáveis, são desconhecidas ou não podem ser determinadas com algum grau de confiança.

MAXIMIANO (2000) afirma que a maior parte das situações enfrentadas pelos administradores não são estruturadas. São situações imprevistas, que necessitam de diagnóstico e que exigem dos mesmos, primeiro a decisão de decidir ou não. Além disto, o administrador não lida com uma decisão de cada vez. Com uma grande freqüência, os inúmeros problemas surgem e ele precisa decidir várias vezes em curtos períodos. A ambigüidade, fator inerente às decisões administrativas, é a situação onde o administrador possui poucas informações para lidar com os problemas organizacionais. BAKER et al. (1998) apresentam como características de problemas não estruturados:

- variáveis essenciais que podem ser simbólicas ou verbais;

- problemas não rotineiros e improgramáveis, com retorno demorado ou informação incompleta;

- objetivos e resultados que podem ser ambíguos ou conflitantes;

- dificuldade para entender o efeito das mudanças nos resultados das decisões, e para predizer o efeitos das ações;

- incerteza sobre quais ações afetam os resultados;

- decisores, freqüentemente, usando métodos imperfeitos, informais ou subjetivos para processar conhecimentos incompletos e imprecisos.

\subsubsection{Elementos do processo decisorial}

Como elementos do processo decisorial, CHIAVENATTO (2000a) lista:

- tomador de decisão: é o indivíduo que faz uma escolha dentre vários cursos de ação disponíveis;

- objetivos: são as metas que o tomador de decisão deseja alcançar por meio de suas ações;

- sistema de valores: critério de preferência que o tomador de decisão usa para fazer sua escolha; 
- cursos de ação: são as diferentes seqüências de ação que o tomador de decisão pode escolher;

- estados da natureza: são aspectos do ambiente que envolvem o tomador de decisão e que afetam sua escolha de cursos de ação. São fatores ambientais fora do controle do tomador de decisões, como condições de certeza, risco ou incerteza;

- conseqüências: são os efeitos resultantes de um determinado curso de ação e de um determinado estado da natureza..

\subsubsection{Etapas do processo decisorial}

URIS (1989), apud BISPO \& CAZARINI (1998), descreve as seguintes fases no processo de tomada de decisão:

1 - análise e identificação da situação: a situação do ambiente onde o problema ou a oportunidade estão inseridos, deve ser claramente identificada, através do levantamento de informações, para que se possa chegar a uma decisão segura e precisa;

2 - desenvolvimento de alternativas: em função do levantamento das informações, ou seja, da coleta de dados, pode se chegar a possíveis alternativas para a resolução do problema proposto;

3 - comparação entre as alternativas: levantamento das vantagens e desvantagens de cada alternativa;

4 - classificação dos riscos de cada alternativa: as decisões sempre envolvem riscos, seja em grau quase nulo, seja em alto grau de risco, ou seja em estágio intermediário;

5 - escolher a melhor alternativa: com o conhecimento das vantagens, desvantagens e riscos, o decisor é capaz de identificar a alternativa que melhor solucione seu problema;

6 - execução e avaliação: a alternativa escolhida fornecerá resultados que deverão ser comparados e avaliados com as previsões anteriores.

A figura 4 ilustra o processo de tomada de decisão: 


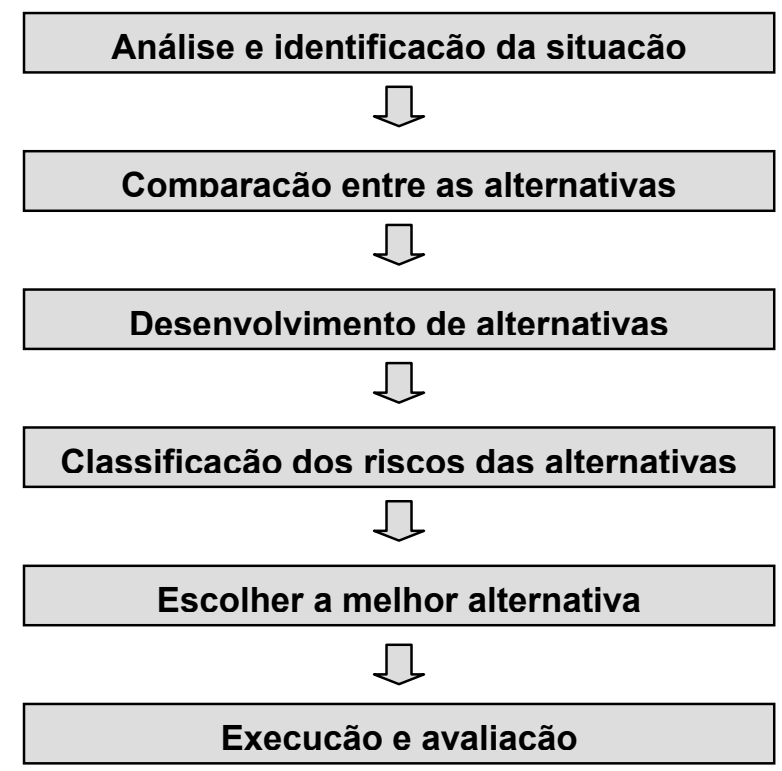

Figura 4 - Etapas do processo decisório

A figura 5 detalha bem o processo decisório, segundo CHIAVENATTO (2000a):

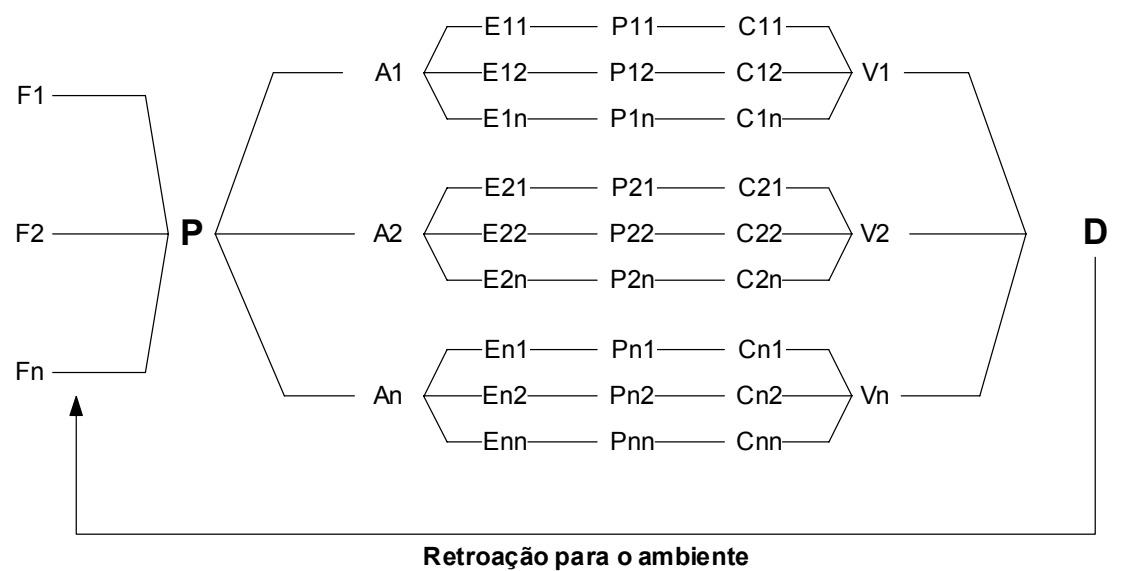

Figura 5 - O processo decisório em detalhes - CHIAVENATTO (2000a)

Como componentes do processo decisório da figura 5, têm-se:

- $\mathrm{F}$ - fatores ambientais

- $\mathrm{P}$ - problema

- A - alternativas de solução

- E - efeitos das alternativas 
- $\mathrm{P}$ - probabilidade de que cada efeito ocorra

- C - classificação dos efeitos conforme sua probabilidade

- $\mathrm{V}-$ escolha das melhores alternativas

- D - decisão

HAMPTON (1990) coloca que existe uma grande diferença entre a abordagem racional e idealizada da decisão, e a realidade organizacional. Porém, o autor afirma que fazer uma abordagem idealizada e totalmente racional da decisão, e a seguir uma comparação entre o ideal e o que realmente ocorre, é uma boa maneira para entender o processo decisório. A figura 6 mostra o processo decisório ideal, de acordo com o autor:

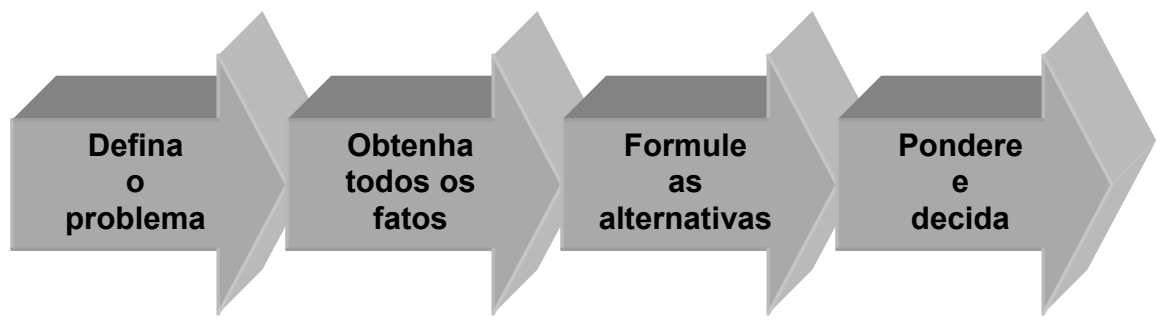

Figura 6 - O processo decisório ideal - HAMPTON (1990)

As etapas, segundo o autor, são comentadas a seguir:

1 - definir o problema: o administrador deve investigar a fundo a fim de definir corretamente o problema. $\mathrm{O}$ autor exemplifica com o trabalho de um médico. Este não pode aceitar passivamente as queixas do paciente e considerar apenas as manifestações superficiais da doença. O médico deve usar os sintomas apresentados para desencadear uma busca mais minuciosa e diagnosticar o problema. Quando os sintomas são erroneamente definidos como problema, ou quando se define o problema de maneira que o pensamento leve a uma solução preconcebida, as chances são poucas para se visualizar uma ampla gama de possíveis soluções. $\mathrm{O}$ autor afirma que existe uma tendência em se definir os problemas em termos prejudiciais, o que torna as possibilidades de solução bem menores.

2 - obter todos os fatos: a primeira coisa a dizer sobre esta fase da tomada de decisão é que nem sempre o administrador obterá todos os fatos. Para ser um administrador eficaz, é necessário aprender a tolerar a ambigüidade, a informação incompleta, a incerteza e ainda decidir. Nesta tarefa, o que pode ajudar é a obtenção seletiva de dados críticos, que conduzem ao centro do 
problema. Esta busca por novos fatos pode ser acelerada ou encurtada, de acordo com a urgência do problema. A busca por informações chega a um ponto em que não se consegue mais esclarecimentos para o problema, momento em que a informação pode tomar mais tempo e custar mais do que o valor em si.

3 - formular alternativas: muitas pessoas aceitam a primeira impressão de um problema como sendo a definição adequada para ele. Partindo disso, formulam apenas uma ou poucas soluções alternativas, muitas vezes, forçadas pela pressão da urgência.

4 - ponderar e escolher: de acordo com a versão ideal da tomada de decisão racional na organização, os objetivos, estratégias, políticas, procedimentos, orçamentos e cronogramas fornecem o contexto para a mesma. Porém a realidade é outra, e a escolha pode ser feita sob condições incertas. Um outro problema é a possibilidade de conseqüências adversas, e neste caso, o processo de tomada de decisão deve esforçar-se para antecipar e calcular tais conseqüências.

\subsubsection{Decisões programadas e não programadas}

CHIAVENATTO (2000a) afirma, que a organização se defronta com uma variedade de problemas em diferentes graus de complexidade, e classifica as decisões tomadas pelos administradores em dois tipos: programadas e não programadas, como mostra a tabela 2 :

Tabela 2 - Características das decisões programadas e não programadas - CHIAVENATTO (2000a)

\begin{tabular}{|l|l|}
\hline \multicolumn{1}{|c|}{ Decisões programadas } & \multicolumn{1}{c|}{ Decisões não programadas } \\
\hline Dados adequados & Dados inadequados \\
\hline Dados repetitivos & Dados únicos \\
\hline Condições estáticas & Condições dinâmicas \\
\hline Certeza & Incerteza \\
\hline Previsibilidade & Imprevisibilidade \\
\hline Rotina & Inovação \\
\hline
\end{tabular}

CHIAVENATTO (2000a), coloca que as decisões programadas são aquelas tomadas de acordo com regras e procedimentos já estabelecidos. Já as decisões não programadas referem-se à novidades e tendem a ser tomadas dentro de julgamentos improvisados, exigindo esforços para diagnosticar o problema ou a situação, na obtenção dos fatos e dos dados. 
O autor também faz uma comparação entre decisões programadas e não programadas e os problemas estruturados e não estruturados, de acordo com a tabela 3:

Tabela 3 - Problemas estruturados e não estruturados e as decisões programadas e não programadas - CHIAVENATTO (2000a)

\begin{tabular}{|c|c|c|}
\hline & \multicolumn{2}{|c|}{ Decisões } \\
\hline Problemas & Programadas & Não programadas \\
\hline Estruturados & $\begin{array}{l}\text { Dados adequados, repetitivos, e } \\
\text { corretos } \\
\text { Previsibilidade } \\
\text { Problemas com situações } \\
\text { conhecidas e estruturadas } \\
\text { Processamento de dados } \\
\text { convencional }\end{array}$ & 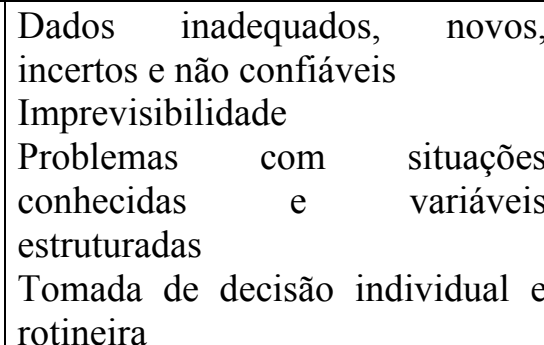 \\
\hline $\begin{array}{c}\text { Não } \\
\text { Estruturados }\end{array}$ & $\begin{array}{l}\text { Dados adequados e repetitivos, } \\
\text { certos e corretos } \\
\text { Previsibilidade } \\
\text { Problemas com situações } \\
\text { conhecidas e não estruturadas } \\
\text { Pesquisa operacional } \\
\text { Técnicas matemáticas }\end{array}$ & $\begin{array}{l}\text { Dados inadequados, novos, } \\
\text { incertos e não confiáveis } \\
\text { Imprevisibilidade } \\
\text { Problemas com situações } \\
\text { desconhecidas e variáveis não } \\
\text { estruturadas } \\
\text { Tomada de decisão individual e } \\
\text { criativa }\end{array}$ \\
\hline
\end{tabular}

\subsubsection{Níveis de decisão organizacional}

CHIAVENATTO (2000b) apresenta três níveis de decisão organizacional:

- decisões estratégicas: relacionadas com as relações entre a empresa e o ambiente; guiam o comportamento da empresa, principalmente quando ela altera sua posição produto/mercado. São tomadas em nível institucional;

- decisões administrativas: relacionadas com a estrutura e configuração organizacional da empresa, com a alocação e distribuição de recursos. São tomadas em nível intermediário;

- decisões operacionais: relacionadas com a seleção e orientação do nível operacional encarregado de realizar a tarefa técnica.

Os níveis de decisão organizacional estão ilustrados na figura 7:

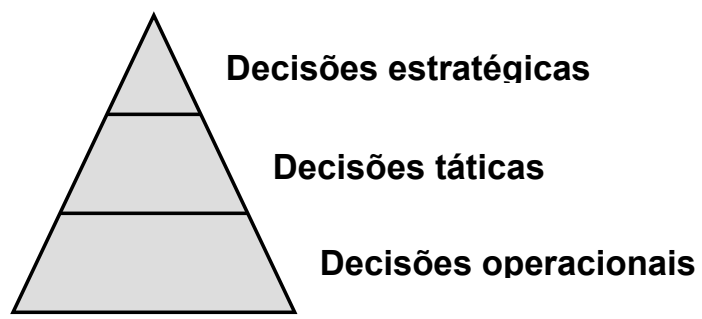

Figura 7 - Níveis de decisão organizacional - CHIAVENATTO (2000b) 


\subsubsection{Condições de decisão}

CHIAVENATO (2000a), afirma que as decisões podem ser tomadas sob três condições:

- incerteza: nas decisões tomadas sob condições de incerteza, o tomador de decisão tem pouco ou nenhum conhecimento ou informação para utilizar como base, ao atribuir probabilidades a cada estado da natureza ou a cada evento futuro. Em casos extremos de incerteza, não é possível estimar o grau de probabilidade de que o evento venha a ocorrer. É a situação típica com que se defronta o nível institucional das empresas;

- risco: nas situações de decisão sob risco, o tomador de decisão tem informação suficiente para predizer os diferentes estados da natureza. Porém, a qualidade dessa informação e sua interpretação, pelos diversos administradores, pode variar amplamente e cada administrador atribuir diferentes probabilidades, conforme sua crença ou intuição, experiência anterior, opinião, etc;

- certeza: nas decisões tomadas sob condição de certeza, o administrador tem completo conhecimento das conseqüências ou dos resultados das várias alternativas de cursos de ação para resolver o problema. É a decisão mais fácil de se tomar, pois cada alternativa pode ser associada aos resultados que pode produzir. Mesmo que o administrador não tenha condições de investigar todas as alternativas disponíveis, ele pode escolher a melhor dentre as consideradas. Esta é uma situação excepcional e não a regra.

A figura 8 mostra as variações de certeza total à incerteza total nas decisões administrativas:

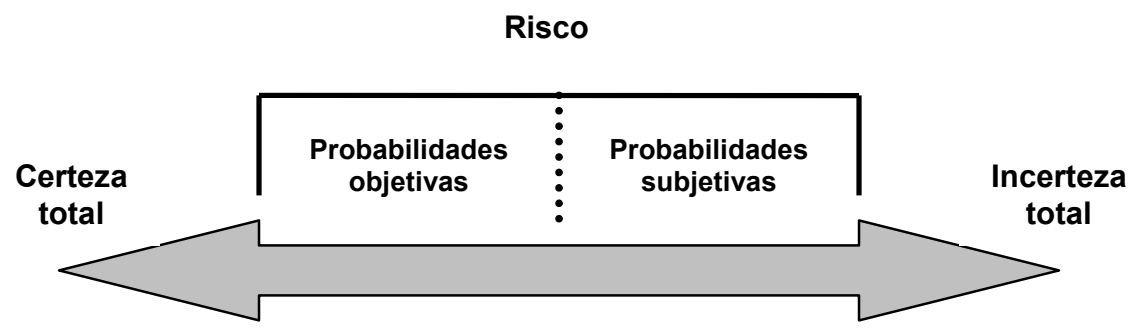

Figura 8 - Condições de decisões - CHIAVENATTO (2000a) 


\subsubsection{A decisão no ambiente organizacional}

De maneira até irônica, HAMPTON (1990, p. 260), descreve como seria o processo decisório ideal: "todas as decisões administrativas se encaixariam maravilhosamente umas nas outras, como cristais de floco de neve. Haveria continuidade e consistência lógica, a partir da definição básica dos objetivos, estratégias, políticas e planos operacionais da organização, bem como das escolhas e dos atos de todos os gerentes e outros funcionários, em toda a organização. A continuidade e a consistência existiriam porque os objetivos, estratégias, políticas, procedimentos, orçamentos e cronogramas forneceriam um contexto no qual as decisões seriam tomadas pelos administradores, funcionando com uma racionalidade tipo computador. As decisões poderiam ser corretas e sempre conferir sucesso à empresa". O autor, ainda ironicamente, afirma que a realidade é outra e que existe uma grande diferença entre a tomada de decisão fácil, ideal e impecável, e a decisão imperfeita e forçada, e afirma que a teoria da administração possui a tendência histórica de ensinar o ideal, enquanto despreza o real.

Como problemas do processo decisório, HAMPTON (1990) afirma que informação em excesso e informações conflitantes constituem causas de erros para os decisores. O autor coloca que o procedimento ideal do tomador de decisão administrativa é como um processador cauteloso da informação. Mas, na prática, devido ao típico retraimento psicológico do conflito desgastante criado pelo processo, a decisão é tomada sem considerar cuidadosamente a informação. Neste mesmo sentido, BISPO \& CAZARINI (1998) afirmam que a quantidade de informações a respeito do problema é um fator de extrema importância para o processo decisório, e quanto mais informações, evidentemente, melhor será a sua compreensão e sua solução. Entretanto os autores alertam para o perigo de informações sem qualidade e sem relevância para o problema.

MINTZBERG (1995), sobre excesso de informação, afirma que os altos gerentes, com poderes para delinear a estrutura da organização, alocam para si todo o poder de decisão, pensando poder fazer melhor do que seus subordinados. Porém, em situações complexas, a situação conhecida como pletora de informações é inevitável: quanto mais informações o cérebro tenta receber, menor a quantidade que realmente ele absorve.

CHIAVENATTO (2000b) escreve que quando há pressão forte para uma solução imediata, etapas do processo decisorial podem ser abreviadas ou suprimidas. Com o objetivo de abastecer o processo decisorial, a organização coleta e processa uma enorme variedade de informações que permitem a escolha de alternativas, em situações que nunca revelam todas as opções disponíveis, nem os possíveis resultados dessas alternativas. A capacidade da organização de coletar e processar essas informações em tempo hábil para o decisor é 
bastante limitada, e este não tem condições de analisar todas as situações, nem de procurar todas as alternativas possíveis. ROBBINS \& COULTER (1998) afirmam que existem limites na capacidade de um indivíduo de processar informação, que os tomadores de decisões tendem a misturar soluções e problemas, e que as informações são selecionadas pelos decisores mais pela sua acessibilidade do que pela sua qualidade.

NUTT (1998) constata que o fracasso nas decisões é tão comum que os executivos agarram-se às características de uma solução aparente, mesmo depois de várias tentativas fracassadas. Em quase $60 \%$ dos casos pesquisados pelo autor, pouco se fizera para identificar alternativas. Em geral, os executivos achavam difícil enfrentar a incerteza e isso os levava a escolher de forma prematura. DALFOVO et al. (1999) verificaram que ainda existem executivos que tomam suas decisões sem que estejam embasados em conhecimentos sobre o mercado ou seus concorrentes, e que alguns não sabem nem o que se passa dentro da própria empresa.

ROBBINS (2000) afirma que a maioria das decisões do mundo real não segue o modelo racional, já que grandes quantidades de decisões precisam ser tomadas rapidamente a fim de buscar a competitividade, e quase todas possuem prazos finais explícitos. ROBBINS \& COULTER (1998) apresentam os pressupostos da racionalidade na tomada de decisão:

- o problema é claro é não é ambíguo;

- um objetivo único e bem sucedido deve ser atingido;

- todas as alternativas e conseqüências são conhecidas;

- as preferências são claras;

- $\quad$ as preferências são constantes e estáveis;

- não existem limites de custo ou tempo;

- a escolha final maximizará o retorno econômico.

Porém, segundo os autores, a racionalidade apresentada nas decisões organizacionais é limitada, pois a maior parte destes pressupostos não ocorre. A tabela 4 apresenta a comparação entre a abordagem da racionalidade perfeita e da racionalidade limitada nas decisões organizacionais:

Tabela 4 - Racionalidade perfeita e racionalidade limitada das decisões - ROBBINS \& COULTER (1998)

\begin{tabular}{|l|l|l|l|}
\hline \multicolumn{1}{|c|}{ Etapa } & \multicolumn{2}{c|}{ Racionalidade Perfeita } & \multicolumn{2}{c|}{ Racionalidade Limitada } \\
\hline $\begin{array}{l}1-\text { Formulação do } \\
\text { problema }\end{array}$ & $\begin{array}{l}\text { Um problema organizacional } \\
\text { importante é identificado }\end{array}$ & $\begin{array}{l}\text { Um problema visível que } \\
\text { reflete os interesses e o } \\
\text { histórico do administrador é } \\
\text { identificado }\end{array}$ \\
\hline $\begin{array}{l}2-\text { Identificação dos } \\
\text { critérios de decisão }\end{array}$ & $\begin{array}{l}\text { Todos os critérios são } \\
\text { identificados }\end{array}$ & $\begin{array}{l}\text { Um conjunto limitado de } \\
\text { critérios é identificado }\end{array}$
\end{tabular}


Tabela 4 - Racionalidade perfeita e racionalidade limitada das decisões - ROBBINS \& COULTER (1998)

\begin{tabular}{|c|c|c|}
\hline $\begin{array}{l}3 \text { - Alocação de pesos } \\
\text { aos critérios }\end{array}$ & $\begin{array}{l}\text { Todos os critérios são avaliados } \\
\text { e são dadas notas em função da } \\
\text { importância para o objetivo da } \\
\text { organização }\end{array}$ & $\begin{array}{l}\text { Um modelo simples é } \\
\text { construído para avaliar e dar } \\
\text { notas aos critérios; o interesse } \\
\text { próprio do tomador de decisão } \\
\text { influencia as notas }\end{array}$ \\
\hline $\begin{array}{l}4-\text { Desenvolvimento } \\
\text { de alternativas }\end{array}$ & $\begin{array}{l}\text { Uma lista completa de todas as } \\
\text { alternativas é desenvolvida de } \\
\text { forma criativa }\end{array}$ & $\begin{array}{llr}\text { Um conjunto } & \text { limitado } & \text { de } \\
\text { alternativas } & \text { similares } & \text { é } \\
\text { identificado } & & \\
\end{array}$ \\
\hline $\begin{array}{l}5 \text { - Análise das } \\
\text { alternativas }\end{array}$ & $\begin{array}{l}\text { Todas as alternativas são } \\
\text { avaliadas de acordo com os } \\
\text { critérios de decisão e seus pesos }\end{array}$ & $\begin{array}{l}\text { Começando com uma solução } \\
\text { escolhida, as alternativas são } \\
\text { avaliadas, uma de cada vez, de } \\
\text { acordo com os critérios de } \\
\text { decisão }\end{array}$ \\
\hline $\begin{array}{l}6 \text { - Seleção de uma } \\
\text { alternativa }\end{array}$ & $\begin{array}{llr}\text { Decisão maximizadora: } & \text { a } \\
\text { alternativa com o maior } \\
\text { resultado econômico para os } \\
\text { objetivos da organização é } \\
\text { escolhida }\end{array}$ & $\begin{array}{l}\text { Decisão satisfatória: procura } \\
\text { contínua até que uma solução } \\
\text { satisfatória e suficiente seja } \\
\text { encontrada, momento em que a } \\
\text { busca pára }\end{array}$ \\
\hline $\begin{array}{l}7 \text { - Implementação da } \\
\text { alternativa }\end{array}$ & $\begin{array}{l}\text { Como a decisão maximiza o } \\
\text { objetivo único e bem definido, } \\
\text { todos os membros da } \\
\text { organização adotarão a solução }\end{array}$ & $\begin{array}{l}\text { Considerações políticas e de } \\
\text { poder influenciarão a aceitação } \\
\text { ou o comprometimento para } \\
\text { com a decisão }\end{array}$ \\
\hline 8 - Avaliação & $\begin{array}{l}\text { O resultado da decisão é } \\
\text { avaliado de maneira objetiva } \\
\text { frente ao objetivo final }\end{array}$ & $\begin{array}{l}\text { A medição é raramente } \\
\text { objetiva, pois não elimina os } \\
\text { interesses do avaliador }\end{array}$ \\
\hline
\end{tabular}

Segundo FULLER (1998), no mundo dos negócios de hoje, a coragem empresarial é testada a cada dia. Os diretores enfrentam grandes desafios e têm de tomar decisões em uma atmosfera de incerteza, mudança e interesses cada vez maiores. BISPO \& CAZARINI (1999) afirmam que diversos fatores estão contribuindo para mudanças na tomada de decisão pelas empresas, como a crescente competição e mercados mais dinâmicos, forçando as empresas a tomarem decisões mais rapidamente, e exigindo estruturas organizacionais mais niveladas, trazendo mais funcionários para este processo. MINTZBERG (1986) afirma que a informação é um insumo fundamental para a tomada de decisões, porém, MINTZBERG (1995) coloca que, quando as mudanças são muitas, os gerentes são obrigados a decidirem com informações inadequadas e abstratas, e que os gerentes que formulam estratégias não podem trabalhar de forma sensata sem a informação necessária.

Segundo BISPO \& CAZARINI (1998), devido às várias mudanças através dos tempos, o mundo tornou-se mais complexo e, conseqüentemente, o processo de tomada de decisão também, pois existem mais fatores influentes do que em outros tempos. Com o surgimento da globalização, da competitividade mais acirrada, e das maiores exigências por 
parte dos clientes, a administração das empresas sofreu uma mudança radical, tornando o processo decisório organizacional muito mais complexo.

ROBBINS \& COULTER (1998) afirmam que o processo decisório começa com a existência de um problema, ou seja, uma discrepância entre o estado atual e o desejado. Porém, a maior parte dos problemas não acontecem de forma explícita, que chamem a atenção de forma atrativa. É necessário reconhecer os problemas, e este processo pode ser muito subjetivo. Além disso, o administrador que, por equívoco resolve o problema errado de maneira correta, pode obter resultados tão ruins quanto o administrador que não consegue identificar o problema correto e se omite. A identificação do problema é um passo complexo e importante no processo de tomada de decisão. Na identificação dos critérios de decisão, o que não é identificado como sendo importante pode ser tão importante quanto o que é. Assim, se o decisor não identifica um critério específico, neste segundo passo, ele será tratado como irrelevante para o problema.

MONTANA \& CHARNOV (1998) colocam que as tomadas de decisão, no passado, tinham um intervalo de tempo durante o qual os dados podiam ser analisados antes de serem utilizados. Atualmente, este intervalo de tempo não existe, e julgamentos terão de ser feitos com mais rapidez sobre a validade e utilidade das informações, em tempo real.

SEELEY \& TARGETT (1999) e MONTANA \& CHARNOV (1998), afirmam que o tempo é provavelmente o recurso mais precioso dos executivos. MONTANA \& CHARNOV (1998) apresentam cinco características singulares sobre o tempo:

- a oferta é totalmente inelástica: não importa a demanda, a oferta é sempre a mesma;

- ele é irrestituível: o momento passado se foi para sempre;

- ele é totalmente perecível: não pode ser armazenado;

- você não pode alugá-lo nem comprá-lo;

- ele está sempre em falta.

\subsection{Informação: o instrumento do administrador}

Diante do ambiente turbulento de seu trabalho, a informação torna-se essencial à atuação dos administradores. DRUCKER (1981), afirma que a informação é o instrumento específico do administrador. CAVALCANTI (1995), coloca que a informação sempre foi um ponto importante para os administradores, mesmo nos idos da administração, quando Henry Fayol definiu o ato de administrar como sendo prever, organizar, comandar, coordenar e controlar; e prossegue, destacando como constatação importante, que a informação é a 
matéria prima básica e fundamental para o trabalho do administrador. Sem ela, as suas atividades ficam inviabilizadas.

Em um mercado altamente competitivo e de forte concorrência, as organizações sabem que a informação é um recurso valioso. STÁBILE \& CAZARINI (2000a) abordam o valor da informação, afirmando que esta constitui, atualmente, o recurso mais importante na condução das organizações, e estas freqüentemente procuram formas de aumentar sua competitividade através do uso estratégico da mesma.

Segundo McCARTHY (1994), todos os anos, milhares de organizações fracassam porque seus administradores falham. $\mathrm{O}$ autor cita as seguintes causas básicas para os fracassos empresariais, dependendo da natureza do negócio:

- má pesquisa de mercado;

- tardio planejamento de produto;

- engenharia deficitária;

- processo fabril que produz má qualidade;

- ineficaz planejamento e implantação financeiros;

- esforço de propaganda insuficiente ou improdutivo;

- métodos de distribuição impróprios para o mercado;

- avultado desperdício em uma ou mais da cinco funções básicas da empresa ;

- falha em motivar o pessoal e/ou desenvolver neles a perícia necessária à execução das funções, e em manter seu aperfeiçoamento no mesmo ritmo das crescentes exigências da empresa.

$\mathrm{O}$ autor prossegue, indagando o leitor da seguinte forma: se as causas citadas, são as causas dos fracassos empresariais, de que maneira se pode justificar a afirmação de que as empresas fracassam porque os administradores falham? E o autor dá como óbvia a resposta, afirmando que as coisas não acontecem por acaso. Os homens fazem com que aconteçam ou impedem que aconteçam, e esses homens são administradores ou estão sob a supervisão de administradores.

Sendo a informação o instrumento específico dos administradores, certamente, se estes tivessem disponíveis as informações necessárias ao seu trabalho, os índices de falhas iriam diminuir. BEUREN (1998), afirma que quanto maior for a sintonia entre as informações fornecidas e as necessidades informativas dos gestores, melhores decisões poderão ser tomadas .

A informação vem ganhando mais e mais importância nas organizações da era da informação. Segundo STEWART (1998), a informação representa cerca de 3/4 do valor agregado das indústrias. Isto mostra porque as empresas investem tanto na tecnologia da 
informação atualmente. De acordo com STRASSMAN, apud STEWART (1998), a economia industrial, baseada no capital, foi superada pela economia da informação, dominada pela gerência.

HUANG \& WINDSOR (1998), evidenciando a importância da informação para o trabalho administrativo, afirmam que muitas das decisões que os executivos tomam, requerem informações apresentadas em uma grande variedade de formatos. Idealmente, diferentes tipos de apresentação de informações podem ser usadas para facilitar diferentes tarefas nas tomadas de decisão.

VAZ (1999), aborda as profundas mudanças provocadas na administração das empresas e dos países, pelas conseqüências econômicas da globalização, e afirma que neste cenário, a informação ganha valor como item fundamental para as novas estratégias de administração que se fazem prementes. GOLDBACH (1998), abordando também a importância da informação para os administradores, no atual cenário competitivo, afirma que o bom desempenho das organizações resulta da combinação de uma série de fatores, e que a previsão do momento e do impacto, que estes fatores podem causar, é praticamente impossível. Prosseguindo, o autor coloca que, somente a informação pode ajudar os administradores a gerenciarem as mudanças e assegurar competitividade e saúde financeira de suas organizações.

Como no atual ambiente concorrencial, com mais ofertas, opções e produtos similares, os clientes são cada vez mais disputados pelas organizações, um diferencial de competitividade é a forma pela qual a organização se relaciona com seus clientes. Quanto melhor for esta relação, maiores chances de sucesso. Também torna-se óbvio que, quanto melhor uma organização gerenciar suas informações, as relações mantidas com os clientes serão mais proveitosas. Vê-se aqui, novamente, destacada a importância da informação para a organização.

Neste sentido, XAVIER \& GOMES (1999), descrevem a importância da informação para a organização e como ela pode ser usada como arma competitiva. Os autores colocam que a informação tornou-se um dos mais importantes ativos das organizações. Sem informações de qualidade, não se consegue atender clientes satisfatoriamente, tomar boas decisões ou obter vantagens de novas tecnologias. Os autores prosseguem afirmando, que o diferencial competitivo da empresa é o conhecimento que ela tem para oferecer ao cliente.

Também abordando a importância da informação e seu uso estratégico, no atual ambiente de competição entre as organizações, ROBIC \& SBRAGIA (1996) afirmam que a informação é um dos fatores decisivos, tanto para efeito de controle interno como para posicionamento perante a concorrência e o mercado. 
Certamente, a informação é uma arma competitiva. Os administradores que contarem com as informações necessárias para suas ações, possuem maior probabilidade de sucesso organizacional. CALDAS \& WOOD (2000) afirmam que não há dúvidas de que o gerenciamento efetivo da informação em uma organização pode ser hoje uma fonte de vantagem competitiva. A TI muda tudo (1999), descreve o valor da informação na organização das empresas, colocando que, hoje, boa parte dos funcionários possui capacidade, autoridade e responsabilidade para tomar decisões. Assim, a maneira como acessam a informação e o uso que fazem dela, têm conseqüências monumentais, podendo levar à produtividade ou à bagunça.

Percebe-se que, qualquer funcionário, independente do nível de responsabilidade dentro da organização, se estiver devidamente informado, desempenhará seu trabalho mais adequadamente do que um outro sem as informações necessárias. Porém, quanto maior for a responsabilidade deste funcionário dentro da organização, maiores serão as conseqüências de seu trabalho. Se este funcionário for um administrador, de posse das devidas informações, seu trabalho terá mais chances de sucesso; porém, sem as devidas informações, seu trabalho terá mais chances de fracasso. Conseqüentemente, a organização é dependente de seu trabalho.

Sendo a tomada de decisão, o núcleo da responsabilidade administrativa (CHIAVENATO 2000a), o bom funcionamento da organização, em busca de seus objetivos, depende de boas decisões tomadas pelos seus administradores. GLAUTIER \& UNDERDOWN, apud BEUREN (1998), e BISPO \& CAZARINI (1998), afirmam que a coleta de informações é uma fase importante no processo decisório. Segundo CHIAVENATO (2000a), as empresas procuram proporcionar às pessoas que nelas tomam decisões, todas as informações de que necessitam e em tempo hábil, para que sejam bem sucedidas nas escolhas. Assim, fica evidenciado a importância do processo decisório organizacional, e também a importância da informação neste processo.

CAVALCANTI (1995) afirma que a probabilidade de acerto de uma decisão sem uma base de informações é praticamente nula, e questiona como ser possível decidir sem o conhecimento através de informações sobre o assunto. $\mathrm{O}$ autor utiliza o exemplo de dirigir um automóvel para ilustrar a utilidade da informação: atenção constante entre observar os indicadores dos instrumentos do painel; percepção atenta para detectar alguma anormalidade; visão atenta para a frente e também atrás, pelo retrovisor. Tudo isto representa informações importantes para a contínua tomada de decisão entre acelerar, reduzir, mudar a direção, mudar a marcha ou mesmo parar. A atuação do administrador na empresa é igual a do motorista: necessidade constante de atenção e de busca por informação para controlar a 
situação. Após a captação de uma informação, é feita uma análise de suas implicações, em seqüência, vem a tomada de decisão, resultando assim em uma ação, e o ciclo se repete indefinidamente. $\mathrm{O}$ autor constata que a informação é a matéria prima básica e fundamental para o trabalho do administrador. Ela vale muito porque através dela a empresa tomará suas decisões mais rápidas e muito provavelmente, mais acertadas. Este processo é mostrado na figura 9:

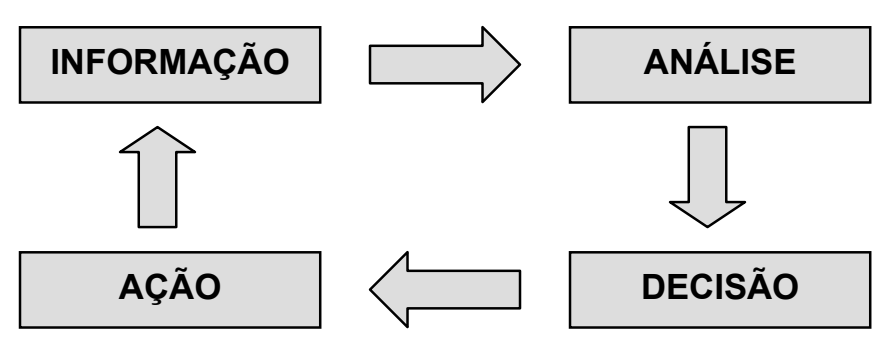

Figura 9 - O uso da informação pelo administrador - CAVALCANTI (1995)

DALFOVO et al. (1999) afirmam que, com a rápida evolução e as mudanças tecnológicas, é fundamental que os executivos tenham grande versatilidade em suas decisões, mas para isso é necessário que tenham em mãos informações precisas e atualizadas. Os administradores defrontam-se constantemente com problemas não estruturados em suas organizações. BAKER et al. (1998), mostram o papel essencial das informações para os administradores. Entre outras, os autores apresentam as seguintes dicas para simplificar problemas não estruturados:

- bloquear informações irrelevantes para o problema;

- prover meios de localização rápida de informação relevantes;

- esclarecer o problema através de níveis progressivos de detalhes;

- prover o usuário com meios de esclarecer afirmações ambíguas;

FIGUEIREDO (1998) afirma que as organizações, cujas pessoas responsáveis pela tomada de decisão estratégica conseguem fazer um trabalho correto e rápido, possuem mais chance de sucesso. Segundo DALFOVO (1998) apud DALFOVO \& GRIPA (1999), se o executivo não utiliza informações como recurso estratégico, este pode administrar por impulsos ou levado por modismos. De acordo com ARANTES (1995) apud SILVA (1998), a informação é um recurso fundamental na definição dos objetivos e rumos para a empresa, na fixação das estratégias e políticas, na avaliação e decisão sobre as alternativas de expansão e investimentos necessários, na avaliação dos resultados de negócio, verificando se estão de acordo com os rumos e objetivos definidos. 
ROBBINS \& COULTER (1998) afirmam que os administradores precisam de informações para controlar a organização, e que sem elas, seria difícil realizar o processo administrativo de forma satisfatória. De acordo com os autores, sendo a informação um recurso vital, os administradores precisam dela para:

- medir o desempenho atual da empresa;

- comparar o desempenho com os padrões planejados;

- preparação de faixas de variação aceitáveis dentro dessas comparações;

- desenvolvimento de cursos de ação apropriados ;

ALMEIDA (1995) coloca que o uso eficaz dos dados disponíveis transformados em informação, é um elemento crítico para o bom desempenho das atividades da empresa, e aumenta em importância a cada dia.

\subsection{Mudanças: a única certeza}

O atual cenário competitivo, exige mais do trabalho administrativo, e torna este mais crítico para as organizações. O ambiente econômico é altamente instável: globalização, abertura de mercados, lançamentos constantes de novos produtos, produtos com ciclos de vida menores, crescimento da oferta, consumidores cada vez mais conscientes e exigentes. As mudanças no contexto econômico têm influências mundiais. A evolução tecnológica oferece cada vez mais opções, e pequenos fatores de diferenciação são grandes geradores de competitividade. Assim, as organizações precisam ter rapidez, flexibilidade e alta percepção. As decisões tomadas pelos administradores tornam-se mais importantes e freqüentes, devendo combinar velocidade e embasamento. Assim, a atuação administrativa torna-se mais crítica e importante para o desempenho das organizações, já que são os administradores que decidem os rumos destas.

$\mathrm{O}$ atual ambiente é instável e turbulento. O número de variáveis que influenciam o desempenho das organizações é crescente, tornando o trabalho administrativo mais complexo. McKENNA (2000), aborda este ambiente afirmando que as mudanças no comportamento do consumidor, as estratégias competitivas e a inexorável força das novas tecnologias estão influenciando simultaneamente as organizações. Os processos são cada vez mais complexos, com um número muito maior do que antes de fatores que influenciam a tomada de decisão. Neste mesmo sentido, BAKER et al. (1998) afirmam que o ambiente de negócios atual é turbulento e complexo, e que as organizações, que se adaptarem rápida e corretamente ao ambiente, têm maiores chances de sobrevivência e prosperidade.

Neste novo ambiente competitivo, fica evidenciado que as mudanças tornam-se constantes, e a velocidade com que acontecem, também representa um agravante ao trabalho 
administrativo. WELCH (2000) coloca que, atualmente as mudanças medem-se em dias, e não mais em anos, trimestres ou meses, e quem não raciocinar nesta mesma velocidade, encontrará problemas, pois velocidade é poder. Neste mesmo sentido, DRUCKER (1981), afirma que o tempo é um recurso escasso, e o administrador está constantemente buscando formas de melhor aproveitá-lo.

NUTT (1998), em uma pesquisa realizada com executivos de organizações de grande e médio porte dos Estados Unidos e Canadá, comprovou que, cerca da metade das decisões, tomadas pelos administradores, fracassou. A cada dia, com um ambiente mais competitivo e concorrencial, as mudanças são constantes. Assim, as decisões tornam-se mais freqüentes e importantes para a organização, e esta passa cada vez mais a depender da atuação de seus decisores.

SILVA (1998), a respeito do novo ambiente competitivo, coloca que a globalização é um fenômeno que proporciona mudanças na administração, quebra paradigmas relativos à estratégia, à posição das empresas no mercado e ao perfil dos atores que atuam na organização. Segundo o autor, a sobrevivência das organizações dependerá de sua capacidade de adaptação ao ambiente externo e interno, e, neste contexto, o administrador possui papel essencial, como o agente principal do processo de mudanças, especialmente no tocante à forma de agir e de decidir os rumos da organização. A tecnologia e a informação são as armas para acompanhar a velocidade dessas mudanças.

MINTZBERG (1986), sobre o trabalho administrativo no novo ambiente concorrencial, coloca que as pressões exercidas sobre os administradores estão tornando-se cada vez piores. No passado, o administrador deveria responder somente aos proprietários e outros diretores. Atualmente, mesmo os subordinados, através de normas democráticas, reduzem a liberdade do administrador em dar ordens sem fornecer explicações coerentes. Simultaneamente, o número crescente de influências externas chamam sua atenção, como grupos de consumidores e órgãos governamentais. BISPO \& CAZARINI (1998), referenciando às pressões que o administrador sofre ao tomar decisões, afirmam que este profissional é exposto a inúmeros fatores de influência internos e externos Todas as pessoas afetadas nas decisões cobram dele um resultado satisfatório. Muitas vezes, clientes, acionistas e empregados solicitam soluções diferentes e até antagônicas para solucionar um problema. O cliente lhe solicita o quarteto: qualidade, preço, entrega e atendimento. Os acionistas exigem garantia de lucro e o retorno sobre o investimento, combinados com o alcance das metas e com a imagem positiva da empresa e de seus produtos. E os empregados pressionam por melhores condições no trabalho, incluindo melhores salários, garantia de emprego, assistência médica e odontológica e outras reivindicações mais específicas. 
As mudanças são constantes e freqüentes. Os estímulos externos multiplicam-se, e as variáveis que influenciam o trabalho administrativo tornam-se mais complexas. $\mathrm{O}$ administrador deve ser o agente que transforma a organização, visando torná-la mais flexível e rápida nas respostas aos estímulos externos. Obviamente, a velocidade de resposta aos estímulos externos e a capacidade de adaptação ao ambiente são fundamentais para o sucesso da organização.

ASHKENAS (1997), sobre as transformações que vem ocorrendo no ambiente concorrencial, e que afetam as organizações e o trabalho dos administradores, coloca que grande parte dos dirigentes ignora o fato de que o sistema organizacional que representam deixou de ser funcional, e que a velocidade da mudança ultrapassou a capacidade de resposta da maior parte das organizações. $\mathrm{O}$ autor prossegue afirmando que o ritmo de mudanças continuará ou até mesmo aumentará, e que modelos consagrados de gestão organizacional serão colocados em dúvida. DRUCKER (1996), cita os fatores que aumentarão a complexidade do trabalho administrativo nos próximos anos:

- o trabalho administrativo será incerto e desafiador, já que infinitas variáveis, mudanças e transformações carregadas de incertezas e de ambigüidades, o atingirão;

- o administrador irá lidar com problemas multifacetados e cada vez mais complexos;

- a atenção do administrador será disputada por eventos e grupos internos e externos à organização, que lhe proporcionarão informações contraditórias, que complicarão seu diagnóstico perceptivo e sua visão dos problemas e situações a resolver;

- exigências da sociedade, dos clientes, fornecedores, agências regulamentadoras, concorrentes, expectativas dos subordinados, acionistas, etc;

- a capacidade de compreensão do administrador será ultrapassada pelas mudanças nas exigências internas e externas, uma vez que estas aumentarão devido à inclusão de novas variáveis, criando uma turbulência que complica o trabalho administrativo.

- concorrência mais aguda, pois, com o aumento dos mercados e dos negócios, aumentam também os riscos da atividade empresarial, onde os melhores produtos e serviços serão os mais procurados. O desenvolvimento de produtos e serviços exigirá maiores investimentos em pesquisa e desenvolvimento; aperfeiçoamento das tecnologias; dissolução de velhos e criação de novos 
departamentos; busca de novos mercados e concorrência com outras organizações, pela sobrevivência e pelo crescimento.

- sofisticação da tecnologia, já que as empresas estarão internacionalizando suas operações e atividades através do uso das telecomunicações, computadores e transportes. A atividade humana estará mais livre para atividades de planejamento e criatividade, já que as tarefas rotineiras serão automatizadas. A tecnologia, através de novos processos e instrumentos, causará impactos sobre a estrutura e comportamento organizacionais.

- a globalização da economia e internacionalização dos negócios; as exportações e subsidiárias em outros países influenciarão as organizações e sua administração.

$\mathrm{O}$ autor afirma que estes fatores trarão para o ambiente organizacional a administração da incerteza, pois as organizações deixarão de lidar com a previsibilidade, continuidade e estabilidade, passando a lidar com a imprevisibilidade, descontinuidade e instabilidade em todos os setores de atividade, requerendo novas formas e modelos organizacionais, bem como nova mentalidade dos administradores.

PRAHALAD (1997) também aborda as mudanças organizacionais, afirmando que a última década foi marcada pela agitação nas idéias, nos conceitos e nas ferramentas administrativas. Dentre elas, o autor cita a qualidade total, a reengenharia, tempos de ciclo, empowerment, liderança transformacional, comportamento e valores sem fronteiras, trabalho conjunto, redes e alianças. Todo este movimento representa uma busca contínua de métodos para lidar com as expressivas lacunas competitivas, e, embora toda iniciativa possa conter idéias importantes, até agora não houve consenso a respeito da natureza mutável da atividade gerencial. A única conclusão indiscutível é que a atividade gerencial será diferente, pois todos os setores de mercado se encontram sob constantes mudanças, influenciados por um subconjunto de descontinuidades.

Percebe-se através da literatura revisada, que o números de fatores que influenciam e pressionam as empresas têm aumentado, assim como a complexidade e a freqüência destes fatores, conforme ilustra a figura 10. Todos os fatores expostos pressionam a empresa simultaneamente, cada um deles exigindo providências diferentes por parte do administrador, que é o profissional responsável pela reação da empresa a estes estímulos. Como agravante, o administrador enfrenta o tempo, cada vez mais curto, pois as mudanças e exigências de ações são constantes, ou seja, o atual ambiente exige do administrador, decisões mais freqüentes, complexas e rápidas. 


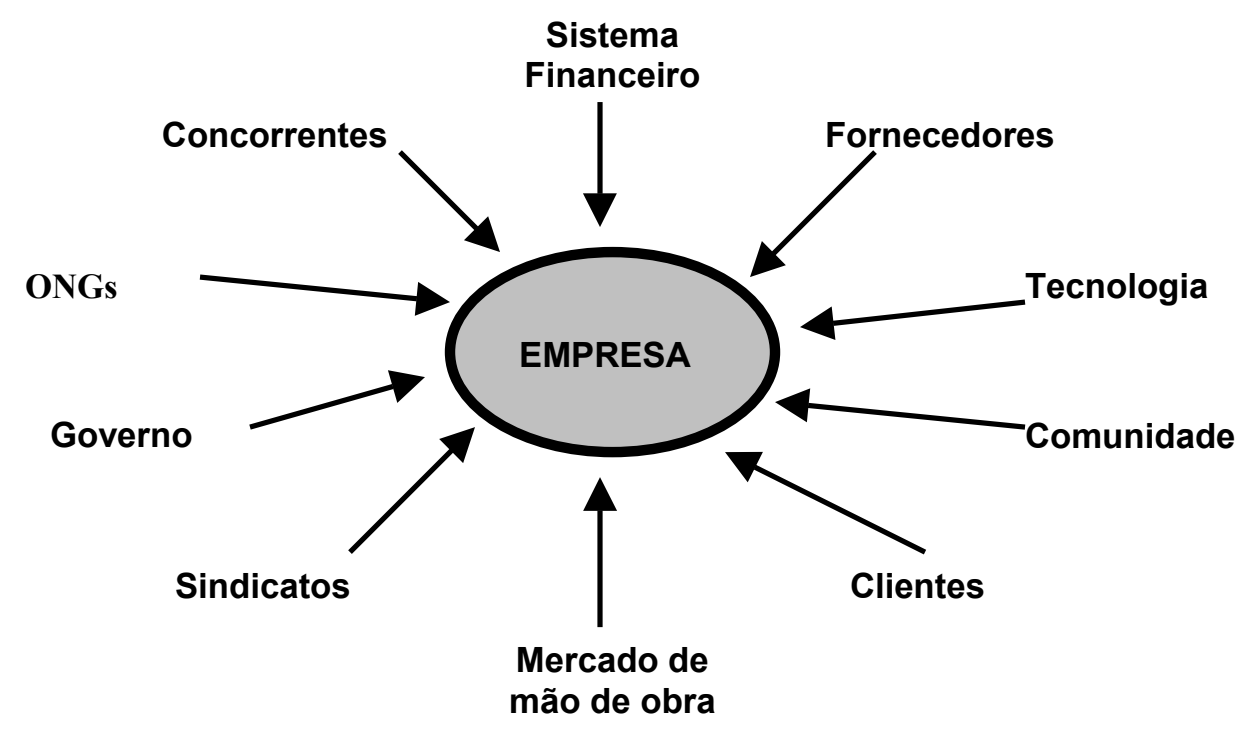

Figura 10 - Fatores que pressionam a empresa

\subsection{Novas estruturas organizacionais}

Vários autores propõe novas estruturas organizacionais. Estruturas mais enxutas e flexíveis, com menos níveis hierárquicos e mais dinâmicas, onde o poder decisório seja exercido por mais funcionários, visando maior agilidade. É consenso entre estes autores de que a estrutura rígida e hierárquica, herança da era industrial, não é mais capaz de acompanhar as mudanças constantes dos novos ambientes competitivos.

Dos vários autores que abordam o assunto, MINTZBERG (1995) é um deles. Este autor afirma que, por anos, a literatura de administração abordou uma estrutura organizacional baseada em regras e em uma rígida hierarquia de autoridade com amplitude de controle. O autor rejeita este tipo de abordagem e propõe uma outra, onde os elementos da estrutura são selecionados para alcançar não só harmonia interna, mas também uma congruência básica com a situação da organização. Assim, o autor afirma que a estrutura organizacional deve ser única para cada organização, onde vários fatores como dimensões, idade, tipo de ambiente inserido e sistema técnico que utiliza, devem ser considerados. $\mathrm{Ou}$ seja, a organização deve ser estruturada de acordo com seu ambiente interno e externo.

Nas empresas rígidas, fortemente baseadas em regras e hierarquias, o autor discorda da padronização e afirma que, mesmo em fábricas bem automatizadas, completamente padronizadas, as máquinas quebram, os empregados deixam de mostrar trabalho e 
programações são mudadas no último minuto. Então, as pessoas são obrigadas a resolver problemas inesperados.

Sobre centralização e descentralização, o autor coloca que são palavras amplamente utilizadas desde quando alguém começou a escrever sobre organizações, e, ainda provavelmente, representem um dos mais confusos tópicos da administração. Os dois termos são utilizados das mais diferentes maneiras, vindo a perder qualquer significado útil. $\mathrm{O}$ autor utiliza o critério de poder de tomada de decisão para examinar a descentralização ou centralização das organizações:

- estando o poder de tomada de decisão em um só local da organização - ou seja, em apenas uma pessoa - esta estrutura é centralizada;

- se o poder de tomada de decisão fica disperso entre muitas pessoas, esta estrutura é descentralizada.

O problema da divisão do trabalho versus coordenação permeia a questão de centralizar ou descentralizar. A centralização é o meio mais cerrado de se coordenar a tomada de decisão organizacional. Então, qual seria o motivo para as organizações buscarem a descentralização? Simplesmente porque nem todas suas decisões podem ser compreendidas em um único centro, ou em uma única mente. $\mathrm{O}$ autor apresenta alguns aspectos sobre o problema:

- as informações necessárias não podem ser transmitidas a tempo para este centro, talvez porque muitas delas sejam difusas e difíceis de transmitir;

- a informação pode ser transmitida para um centro, mas não pode ser ali compreendida;

- mesmo se um relatório específico fosse feito a respeito de cada assunto, o tomador de decisão perderia tempo em estudá-los;

- o sofisticado sistema de informações gerenciais pode dar a ilusão do conhecimento, sem a capacidade de ser absorvido;

$\mathrm{O}$ autor afirma que, quanto mais complexo o ambiente, mais descentralizada deve ser a estrutura, visando maior dinamismo nas respostas às mudanças ambientais, já que a transmissão de informações de e para o centro, demanda um tempo que pode ser crucial.

MONTANA \& CHARNOV (1998), sobre a discussão entre centralização e descentralização, apresentam as vantagens da centralização:

- controle mais próximos das operações;

- uniformidade nas políticas, nas práticas e nos procedimentos;

- melhor uso de peritos centralizados e especializados.

E as vantagens da descentralização: 
- tomada de decisão mais rápida, sem ter de recorrer aos altos níveis para consultas;

- excelente experiência de treinamento para promoções aos níveis mais altos da administração;

- as decisões adaptam-se melhor às condições locais.

MINTZBERG (1995) define o meio ambiente no qual a organização está inserida, como sendo tudo aquilo externo à organização: sua tecnologia, a natureza de seus produtos, os clientes e competidores, a localização geográfica, o clima econômico e político, etc. Para o meio ambiente organizacional, o autor apresenta quatro dimensões:

- estabilidade: pode variar do estável ao dinâmico. Vários fatores podem tornar o ambiente dinâmico, entre os quais governos instáveis, mudanças econômicas, mudanças em pedidos de clientes, comportamento dos competidores, demanda por criatividade do cliente, freqüente inovação, rápidas mudanças tecnológicas. O dinâmico aqui significa imprevisível e não variável, pois a variabilidade pode ser previsível;

- complexidade: pode variar do simples ao complexo. Como exemplo de ambiente simples, tem-se o fabricante de caixas dobráveis, que manufatura seus produtos simples utilizando conhecimento simples. Um ambiente dos mais complexos seria uma agência espacial, que utiliza conhecimento dos mais diversos campos.

- diversidade de mercado: podem variar de integrado a diversificado. A diversidade pode resultar de uma ampla faixa de clientes, produtos, serviços, áreas geográficas, etc.;

- hostilidade: influenciada pela competição, pelas relações da organização com sindicatos, governos e outras entidades externas.

Para exemplificar ambientes estáveis e instáveis, e sua influência organizacional, o autor utiliza as forças armadas:

- ambiente estável: as forças armadas, em tempos de paz, são altamente burocratizadas, padronizadas e primam pela disciplina e pelo planejamento. Em um ambiente estável, a organização pode predizer suas condições futuras, planejar e padronizar suas atividades, tornando-se um sistema protegido ou imperturbado;

- ambiente instável: já no campo de batalha, existe a necessidade de maior flexibilidade nas condições dinâmicas de guerrilha, e a estrutura torna-se menos rígida. Ao enfrentar fontes incertas de suprimentos, demandas imprevisíveis de clientes, alta rotatividade de pessoal, condições políticas instáveis, mudanças 
tecnológicas, a organização não consegue predizer seu futuro facilmente e a padronização perde seu sentido. Ela deve usar um mecanismo de coordenação mais flexível e menos formal, chamado de estrutura orgânica.

Sobre a influência do ambiente na estrutura da organização, o autor afirma que ambientes dinâmicos levam a estruturas orgânicas e que ambientes estáveis levam a estruturas burocráticas. Este último tipo, altamente formal e padronizado, chamado pelo autor de burocracia mecanizada, não encontra problemas de adaptação se o ambiente permanecer perfeitamente estável. Os problemas rotineiros são tratados pelos procedimentos padronizados e os não rotineiros, deixam de aparecer. Mas como os ambientes inevitavelmente mudam, os gerentes da cúpula destas estruturas ficam sobrecarregados. A tendência de passar os problemas não rotineiros hierarquia acima causa um engarrafamento no topo, forçando os gerentes a decidirem rapidamente sobre as mais variadas áreas da organização. $\mathrm{O}$ autor questiona como decidir com rapidez sobre problemas de áreas com as quais estes gerentes não têm contato íntimo.

Outro autor, SAVAGE (1996) também condena a tradicional estrutura hierárquica encontrada nas organizações, e propõe uma nova estrutura e uma nova metodologia de trabalho - a rede - onde a comunicação e integração entre todos na empresa são utilizadas para acompanhar o ambiente dinâmico e competitivo. $\mathrm{O}$ autor afirma que o mundo dos negócios está mudando de modo dramático, pois os nichos protetores de mercado, e também o isolamento geográfico, não existem mais. Há trinta anos, a preocupação era com o custo: reduzir o custo do produto; agora, o tempo é a preocupação: reduzir o tempo do produto.

Sobre a tecnologia da informação, o autor afirma que as promessas de flexibilidade e a adaptabilidade continuam fora do alcance das organizações por causa das disputas contínuas de territórios, das políticas provincianas e dos sistemas rígidos de controle. Devido ao novo ambiente competitivo, integração é essencial quando as companhias querem tornarse mais confiáveis e ágeis para lidar com a complexidade sempre mutante dos mercados globais. A organização, funcionando em rede, é necessária quando se espera trabalhar mais em paralelo através das várias funções, como vendas, marketing, engenharia, manufatura, finanças e serviços. Integração e redes são condições prévias, quando se quer administrar as múltiplas alianças estratégicas com fornecedores, parceiros e clientes.

O autor coloca que, certamente não falta visão quanto ao que as organizações gostariam de promover buscando serem competitivas. Contudo elas se encontram presas à herança da era industrial: uma constelação de suposições, princípios e valores que impedem os esforços e que aprisionam todos a modos tradicionais de comportamento. Vários departamentos defendem zelosamente seu terreno, suas prerrogativas, duramente adquiridas. 
Ao sopro do vento da mudança, as funções em geral agarram-se aos troncos de suas árvores em busca de proteção. Pequenos impérios existem por toda a parte em quase todas as organizações.

Sobre integração nas estruturas hierárquicas, o autor afirma que muitos pensam somente em termos de conectividade física, mas esta é apenas uma parte do desafio. O problema é que muitas organizações funcionam como uma coleção de frações. A engenharia vê apenas uma fração dos problemas que a função industrial enfrenta ao operar. A industrial não gosta dos problemas de serviço no campo. E muitas vezes a alta gerência tem apenas uma compreensão fracionada do que realmente acontece no piso de fábrica. Este problema não será resolvido por conectividade e interface. Na organização em rede, segundo o autor, à medida que as pessoas passam a se verem como fontes capazes de alcançar resultados por si e de participar de equipes focadas em múltiplas tarefas, as organizações serão capazes de focar e coordenar mais eficientemente os recursos da empresa.

$\mathrm{O}$ autor afirma que na era industrial, acreditava-se que era possível planejar tudo antes da hora, dividir o trabalho entre várias funções, depois monitorar e controlar o que é feito para terminar no ponto desejado, como um navio na linha do oceano; mantê-lo no curso. Este modelo está fora de sintonia com as expectativas de freqüentes mudanças do mercado: precisa-se de um barquinho para adaptações rápidas. A era industrial definiu recursos fixos. A era do conhecimento precisa lançar mão de recursos variáveis ou virtuais para satisfazer demandas singulares de mercado de maneira oportuna, configurando e reconfigurando as adequadas capacidades competências dentro e entre empresas, para dimensioná-las às concretas oportunidades rentáveis do mercado.

Um outro problema em hierarquias rígidas é o gerenciamento da informação. $\mathrm{O}$ autor afirma que este gerenciamento é feito por uma pessoa que possui relacionamento direto com o poder naquela área. Em muitas organizações a informação tornou-se moeda corrente, distribuída aos amigos e não a outros. Um dos principais dogmas de hierarquias íngremes é a noção de direito ou propriedade de alguma pessoa, quer individual ou funcional. Esta é a mensagem implícita no proverbial organograma da organização. Não é de admirar que a informação deva ser gerenciada e a luta política seja um meio de vida.

Ainda sobre velocidade e mudanças, o autor coloca que o relógio da interação organizacional acelera-se quando as companhias são requisitadas a responder mais rapidamente às mudanças de mercado. Estas mudanças estão forçando as funções a trabalharem mais interativamente em vez de seqüencialmente, e enquanto as empresas persistirem em departamentos e linhas, em propriedades destes departamentos, e em 
propriedade de dados, a colaboração entre múltiplas funções continuará sendo politizada em um clima de desconfiança, e a fragmentação persistirá.

Segundo o autor, a divisão do trabalho em divisões e departamentos da era industrial, causa vários problemas hoje às empresas. Enquanto cada uma das funções está preocupada em apegar-se ferrenhamente ao seu organograma estreitamente definido, e em escolher seu próprio interesse, não é surpreendente que as idéias caiam por entre as frestas e se afoguem num mar de políticas, com os gerentes recolhendo-se às suas tocas, protegidos por arame farpado.

MAXIMIANO (2000) compara na tabela, 5 algumas características tradicionais da sociedade industrial e sua contrapartida no século XXI:

Tabela 5 - Características tradicionais e características do século XXI - MAXIMIANO (2000)

\begin{tabular}{|l|l|}
\hline \multicolumn{1}{|c|}{ Características tradicionais } & \multicolumn{1}{|c|}{ Características no século XXI } \\
\hline $\begin{array}{l}\text { Revolução Industrial: substituição e e } \\
\text { potencialização do trabalho humano por } \\
\text { meio de máquinas }\end{array}$ & $\begin{array}{l}\text { Revolução Digital: substituição e } \\
\text { potencialização das funções humanas de } \\
\text { decisão, comunicação e processamento de } \\
\text { informações por computadores }\end{array}$ \\
\hline $\begin{array}{l}\text { Classe operária numerosa, em conflitos com } \\
\text { uma classes de patrões e gerentes }\end{array}$ & $\begin{array}{l}\text { Trabalhadores em serviços, profissionais } \\
\text { liberais e trabalhadores do conhecimento } \\
\text { mais numerosos que os operários clássicos }\end{array}$ \\
\hline $\begin{array}{l}\text { Trabalhador especializado; operador de } \\
\text { máquinas, qualificado apenas para a a a } \\
\text { realização de pequena parte da tarefa total }\end{array}$ & $\begin{array}{l}\text { Grupos de trabalhadores auto-geridos e } \\
\text { polivalentes. Em certos casos, o trabalho na } \\
\text { linha de produção requer educação } \\
\text { universitária }\end{array}$ \\
\hline Emprego e carreira estáveis & $\begin{array}{l}\text { Desemprego, empregabilidade, } \\
\text { Terceirização, economia informal, } \\
\text { administração empreendedora. }\end{array}$ \\
\hline
\end{tabular}

ASHKENAS (1997) também aborda a nova realidade organizacional. A respeito das mudanças ambientais e organizacionais, o autor afirma que o ritmo de mudança rápido e cheio de nuanças se manterá ou mesmo aumentará, e as organizações agora enfrentarão a questão de como andar sobre a crista dessa onda gigantesca de mudança, em vez de bater-se contra as rochas, já que até modelos inquestionáveis de excelência organizacional serão colocados em cheque.

Segundo o autor, o ritmo da mudança ultrapassou a capacidade de resposta da maior parte das organizações, que no futuro certamente agirão de forma diferente, uma forma denominada "sem fronteiras", onde os padrões de comportamento, hoje reprimidos e bloqueados pelos limites há muito existentes, serão rompidos. $\mathrm{O}$ autor cita, os limites entre níveis e funções organizacionais, entre fornecedores e clientes e entre localizações 
geográficas. Estes limites serão substituídos por movimentos livres, e não haverá mais separações entre pessoas, tarefas, processos e lugares. Ao contrário, o foco dessas organizações se concentrará em como atravessar essas fronteiras: transferir rapidamente idéias, informações, decisões, recursos, recompensas e providências para onde são mais necessários.

$\mathrm{O}$ autor afirma que a maior parte das organizações não parece funcionar muito diferente daquelas de 20,30 ou 50 anos atrás; que a hierarquia baseada no controle - com múltiplos níveis, divisões funcionais, papéis e recompensas diferenciados e informações fragmentadas - é ainda o modelo organizacional predominante.

A respeito das organizações hierárquicas, o autor coloca que as fronteiras rígidas surgiram em boa parte das organizações como um meio de assegurar a estabilidade e a ordem organizacional. Para favorecer essa estabilidade, um grande número de ferramentas e estruturas foi desenvolvido, e finalmente, modelou a natureza do comportamento nas organizações modernas. Na essência, as organizações fortaleceram a estabilidade através de uma série de controles intrincados e inter-relacionados, geralmente administrados por uma gerência sênior e por vários grupos assistentes (pessoal, finanças, jurídico, qualidade e outros). Em um ambiente relativamente estável, estes controles funcionaram bem quando o desempenho ou o comportamento apresentava desvios em relação aos padrões normais, e foram responsáveis por grandes avanços. Porém, atualmente, as oscilações não são mais controláveis, e a organização precisa ficar solta e livre para atravessar a maré da mudança e se lançar em novas direções, devendo ser ágil e flexível, capaz de mudar de direção rapidamente e de inovar continuamente.

Dentre as fronteiras ou limites existentes hoje nas empresas, e que devem tornar-se flexíveis, o autor cita o limite vertical, entre os níveis e as posições das pessoas: quando os limites verticais se tornam mais permeáveis, a posição é menos relevante do que a competência. Normalmente isto leva a um processo decisório melhor, mais rápido e próximo da ação, e a um acesso maior às idéias, em qualquer parte da na organização.

HEHN (1999), também condena as tradicionais estruturas departamentais. Segundo o autor, nestas empresas a noção de território é muito forte, e todos se sentem donos de suas áreas, passando a defendê-las. Muitas áreas são fechadas, sem nenhuma transparência, e a lealdade para com a área é maior do que para com a organização. As pessoas agem como se fossem "meu território", "minhas informações". Como resultado, tem-se:

- redundância de atividades entre as áreas;

- falta de comunicação e cooperação entre as áreas;

- competição entre as áreas; 
- ineficiência organizacional, ciclos longos, muito tempo de espera entre atividades, etc ;

- falta de visão do todo.

Comparando as informações às cartas em um jogo de baralho, o autor afirma que elas são tratadas da seguinte forma, neste ambiente:

- não deixe que os outros vejam suas cartas;

- cuidado ao passar cartas para os outros, pois eles podem usá-las em jogo para ganhar de você;

- se você mostrar-se interessado em um determinado tipo de cartas, seus adversários irão segurá-la. Aja naturalmente;

- blefe, faça os outros pensarem que você têm cartas que, na verdade, não têm;

- as cartas que você acumula representam pontos a seu favor;

- sem que os outros percebam, procure passar cartas para seu parceiro de jogo.

Segundo o autor, as empresas deveriam adotar uma estrutura integrada e orientada para processos, que seria bem mais eficaz no atual ambiente. A tabela 6 apresenta a comparação do autor entre as empresas departamentais e a integradas:

Tabela 6 - Organizações departamentais e organizações orientadas para processos - HEHN (1999)

\begin{tabular}{|l|l|}
\hline \multicolumn{2}{|c|}{ Mepartamental Tradicional mentais, valores e crenças } \\
\hline $\begin{array}{l}\text { Malorização da propriedade, do poder } \\
\text { hierárquico, da relação entre chefe e e } \\
\text { subordinado }\end{array}$ & $\begin{array}{l}\text { Valorização das redes de relacionamento, da } \\
\text { relação entre pares nos fluxos dos processos }\end{array}$ \\
\hline $\begin{array}{l}\text { O chefe tem o papel fundamental de cobrar e } \\
\text { motivar os funcionários }\end{array}$ & $\begin{array}{l}\text { Além dos chefes, os pares exercem pressão e } \\
\text { motivam uns aos outros para alcançarem } \\
\text { objetivos comuns }\end{array}$ \\
\hline $\begin{array}{l}\text { A informação pertence a quem a gerou; } \\
\text { informação é poder }\end{array}$ & $\begin{array}{l}\text { Toda informação deve ser colocada no } \\
\text { sistema integrado, que fará dela uso } \\
\text { adequado e a liberará para as pessoas } \\
\text { autorizadas }\end{array}$ \\
\hline Objetivos e responsabilidades específicas & $\begin{array}{l}\text { Objetivos comuns, responsabilidades } \\
\text { específicas }\end{array}$ \\
\hline $\begin{array}{l}\text { Atividades basicamente agrupadas por } \\
\text { função, visando ganhos de escala entre } \\
\text { atividades similares }\end{array}$ & $\begin{array}{l}\text { Adota-se o agrupamento mais vantajoso para } \\
\text { o conjunto, tanto pode ser por função como } \\
\text { por processo }\end{array}$ \\
\hline Tendência a formar especialistas & $\begin{array}{l}\text { Tendência a formar pessoas com visão de } \\
\text { processo }\end{array}$ \\
\hline \multicolumn{2}{|c|}{ Padrões de comportamento } \\
\hline Defesa da propriedade & \begin{tabular}{l} 
Defesa de objetivos comuns \\
\hline E importante é fazer o chefe feliz \\
fluxo dos processo, felizes
\end{tabular} \\
\hline
\end{tabular}




\section{Tabela 6 - Organizações departamentais \\ e organizações orientadas para processos - HEHN (1999)}

\begin{tabular}{|c|c|}
\hline $\begin{array}{l}\text { Relacionamento pessoais concentrados na } \\
\text { área funcional onde a pessoa atua }\end{array}$ & $\begin{array}{l}\text { Relacionamentos pessoais distribuídos pela } \\
\text { organização em função do processo }\end{array}$ \\
\hline \multicolumn{2}{|c|}{ Resultados } \\
\hline $\begin{array}{l}\text { Reforçam a importância da especialidade, da } \\
\text { necessidade de comando forte e presente } \\
\text { para integrar as pessoas }\end{array}$ & $\begin{array}{l}\text { Reforçam o valor da gestão por processos, a } \\
\text { eficácia da pressão dos pares no alcance dos } \\
\text { objetivos comuns }\end{array}$ \\
\hline $\begin{array}{l}\text { Feudos, duplicidade de atividades, ciclos } \\
\text { longos com muito tempo de espera }\end{array}$ & Times virtuais, integração, ciclo curtos \\
\hline Visão setorial prevalecendo sobre o todo & $\begin{array}{l}\text { Resultados globais mais importantes que } \\
\text { setoriais }\end{array}$ \\
\hline
\end{tabular}

MARCHAND (1999a) também aponta problemas no gerenciamento de informações nas organizações departamentais. $O$ autor afirma que na organização tradicional departamental, os dados são utilizados isoladamente nos departamentos de origem, onde grupos específicos aplicam seus conhecimentos. Como problema, tem-se que os departamentos são determinados pela perspectiva funcional da empresa, e não por uma perspectiva ampla da administração geral, e a interpretação dos dados é afetada por pressupostos obscuros. Nas empresas deste tipo, a informação estratégica existe só no topo, ao passo que, nas empresas organizadas por processos, nem toda responsabilidade de decisão situa-se no topo da mesma, e a informação estratégica deve ser organizada conforme as necessidades organizacionais. O autor afirma que, no atual ambiente dinâmico, é impossível para os administradores do topo, monitorarem e decidirem tudo, e que as demais pessoas estão mais próximas dos problemas e das mudanças, podendo reagir mais rápido, porém, necessitando de informação.

O autor compara, na tabela 7 , as duas abordagens para o processo de informação competitiva nas organizações:

Tabela 7 - Dimensões-chave das abordagens

centralizada e descentralizada - MARCHAND (1999a)

\begin{tabular}{|l|l|l|}
\hline \multicolumn{1}{|c|}{ Dimensões-chave } & \multicolumn{1}{|c|}{ Abordagem centralizada } & Abordagem descentralizada \\
\hline Cultura da informação & Controle & Partilha \\
\hline Orientação futura & $\begin{array}{l}\text { Informação para decisões- } \\
\text { chave }\end{array}$ & $\begin{array}{l}\text { Abertura para aprender/ } \\
\text { desaprender }\end{array}$ \\
\hline Estrutura & Vertical & Paralela \\
\hline Processo & Altamente centralizado & Altamente interativo \\
\hline Âmbito & $\begin{array}{l}\text { Orientada para a alta } \\
\text { administração }\end{array}$ & $\begin{array}{l}\text { Aprendizagem por parte da } \\
\text { direção }\end{array}$ \\
\hline Horizonte temporal & Curto/Médio prazo & Médio/Longo prazo \\
\hline Papel da TI & Operacional & Estratégico \\
\hline Memória organizacional & Centralizada; banda estreita & Aberta/Banda larga \\
\hline
\end{tabular}


PECI (1999) também condena a empresa hierárquica integrada verticalmente, afirmando que ela se mostrou válida nas condições de produção em massa e na existência de mercados oligopolistas. Porém, com as drásticas mudanças econômicas, tecnológicas e institucionais, ela se mostra ineficiente, por sua extrema rigidez, que não se adequa em condições de incerteza e altas variações, típica do ambiente contemporâneo de negócios. Assim, o autor afirma que as redes organizacionais - estruturas flexíveis, integradas, visando eficiência coletiva - ganham importância. Na tabela 8 , o autor compara os dois tipos de sistemas presentes nas empresas, os mecanicistas e os orgânicos

Tabela 8 - Sistemas

mecanicistas e sistemas orgânicos - PECI (1999)

\begin{tabular}{|c|c|}
\hline Sistemas mecanicistas & Sistemas orgânicos \\
\hline Tarefas bem definidas e atribuídas & $\begin{array}{l}\text { Ajustamento contínuo e redefinição de } \\
\text { tarefas com base no conhecimento }\end{array}$ \\
\hline Decisões centralizadas na cúpula da empresa & Decisões descentralizadas \\
\hline Comunicações e interações verticais & $\begin{array}{l}\text { Interações e comunicações em qualquer } \\
\text { nível, de acordo com as necessidades do } \\
\text { processo }\end{array}$ \\
\hline $\begin{array}{l}\text { Lealdade à empresa e obediência ao } \\
\text { superiores }\end{array}$ & $\begin{array}{l}\text { Envolvimento e compromisso com os fins } \\
\text { da organização como um todo }\end{array}$ \\
\hline $\begin{array}{l}\text { Hierarquia clara de controle e coordenação } \\
\text { (burocracia) }\end{array}$ & $\begin{array}{l}\text { Sistema estratificado de acordo com o nível } \\
\text { de conhecimento } \\
\text { (tecnocracia) }\end{array}$ \\
\hline
\end{tabular}

O autor afirma que o sistema mecanicista é mais adequado às condições estáveis do ambiente, e o sistema orgânico é mais apropriado num ambiente altamente mutável; nas empresas que trabalham integradas, em forma de redes, a informação e sua divulgação tornase cada vez mais importante.

TAPSCOTT (1999) coloca que o modelo de empresa com hierarquia de comando e controle, teve origem há séculos e não funciona mais no atual ambiente. Este ambiente burocrático cria resistência à mudança, e faz com que as decisões sejam lentas. $\mathrm{O}$ autor afirma que hoje necessitamos de modelos intercomunicantes, com cooperação e trabalho em equipe. NADLER \& THSUMAN (2000) afirmam que a capacidade da empresa de compreender o ambiente e fazer alterações estratégicas necessárias, no momento certo do ciclo de mudanças, determina sua força competitiva. Os autores afirmam que a mudança tornou-se parte da vida da empresa, e que a velocidade cada vez maior das mudanças, desfigura o tempo e o espaço da empresa, alterando o próprio formato desta. A empresa deve entender estas mudanças e reagir adequadamente a elas, devendo desenvolver arquiteturas 
organizacionais não convencionais, flexíveis e adaptativas, que a capacitem para um desempenho eficaz, diante da incerteza.

SEFERTZI (2000) afirma que o modelo organizacional, baseado na produção em massa e na empresa integrada verticalmente, foi descartado devido a sua rigidez e ineficiência no novo ambiente competitivo. Muitos consideram que modelos mais flexíveis sejam a forma que predominará no futuro por sua capacidade de se adaptar logo à demanda flutuante. ROBBINS (2000), como características da nova organização, entre outras, cita o desmantelamento da hierarquia para aumentar a flexibilidade e a participação dos funcionários nas decisões. FULLER (1998) afirma que os diretores de empresa sabem, que na estrutura militar das organizações, as informações obtidas não conseguem geralmente chegar ao lugar certo, e quando chegam, o problema está na lentidão das decisões, pois, ao puxar-se o gatilho, o alvo já mudou de lugar. ROBBINS \& COULTER (1998), sobre agilidade e capacidade de adaptação ao ambiente, afirmam que no atual mundo dos negócios, em constante mutação, as empresas devem ajustar-se rapidamente a ele para sobreviverem, devendo desenvolver habilidades de flexibilização, e a rapidez, nestas adaptações, também é vital à sobrevivência.

CHIAVENATTO (2000b) também escreve a respeito da nova realidade organizacional, afirmando que a organização burocrática atual, será substituída nos próximos anos, por novas arquiteturas organizacionais, adequadas às novas demandas da era pósindustrial. Como características do novo ambiente organizacional, o autor cita a informação, como sendo a principal fonte de energia da organização, seu principal combustível e o mais importante recurso ou insumo. Segundo o autor, as mudanças são rápidas e incessantes, e neste ambiente, a administração torna-se um artigo de primeira necessidade, não sendo mais possível implementar, estratégias para enfrentar os desafios da era da informação, em estruturas organizacionais e com executivos da era clássica. O autor compara as eras administrativas, como mostra a tabela 9:

Tabela 9 - As três eras da administração do século XX - CHIAVENATTO (2000b)

\begin{tabular}{|c|c|c|}
\hline $\begin{array}{l}\text { Era } \\
\text { Clássica } \\
(1900-1950)\end{array}$ & $\begin{array}{ll}\text { - } & \text { início da industrialização } \\
\text { - } & \text { estabilidade } \\
\text { - } & \text { pouca mudança } \\
\text { - } & \text { previsibilidade } \\
\text { - } & \text { regularidade e certeza }\end{array}$ & $\begin{array}{ll}\text { - } & \text { administração científica } \\
\text { - } & \text { teoria clássica } \\
\text { - } & \text { relações humanas } \\
\text { - } & \text { teoria da burocracia }\end{array}$ \\
\hline $\begin{array}{l}\text { Era } \\
\text { Neoclássica } \\
(1950-1990)\end{array}$ & $\begin{array}{ll}\text { - } & \text { desenvolvimento industrial } \\
\text { - } & \text { aumento da mudança } \\
\text { - } & \text { fim da previsibilidade } \\
\text { - } & \text { necessidade de inovação }\end{array}$ & $\begin{array}{ll}- & \text { teoria neoclássica } \\
- & \text { teoria estruturalista } \\
- & \text { teoria comportamental } \\
- & \text { teoria de sistemas } \\
- & \text { teoria da contingência }\end{array}$ \\
\hline
\end{tabular}


Tabela 9 - As três eras da administração do século XX - CHIAVENATTO (2000b)

\begin{tabular}{|c|c|c|}
\hline $\begin{array}{l}\text { Era da } \\
\text { Informação } \\
\text { (após 1990) }\end{array}$ & $\begin{array}{ll}\text { - } & \text { tecnologia da informação } \\
\text { - } & \text { globalização } \\
\text { - } & \text { ênfase nos serviços } \\
\text { - } & \text { aceleração da mudança } \\
\text { - } & \text { imprevisibilidade } \\
\text { - } & \text { instabilidade e incerteza }\end{array}$ & \begin{tabular}{ll}
\multicolumn{2}{l}{ Enfase na: } \\
- & produtividade \\
- & qualidade \\
- & competitividade \\
- & cliente \\
- & globalização
\end{tabular} \\
\hline
\end{tabular}

O autor apresenta algumas tendências organizacionais do mundo moderno:

- cadeias de comando mais curtas: a tendência atual é de enxugar níveis hierárquicos na busca de organizações não hierárquicas, enxutas e flexíveis;

- menos unidade de comando: a ênfase horizontal do processo está ocupando o lugar da hierarquia vertical. A tendência atual é de utilizar equipes funcionais cruzadas, forças-tarefas e estruturas horizontais para aproximar o funcionário do cliente;

- amplitudes de controle mais amplas: visando reduzir a supervisão direta e facilitar a delegação de responsabilidade e maior autonomia às pessoas;

- maior participação: transferência de responsabilidades e decisões às pessoas, visando maior autonomia e respostas mais rápidas aos estímulos;

- equipes de trabalho: definitivas ou transitórias, ao invés dos tradicionais departamentos. Essa aparente desorganização do trabalho, significa uma orientação rumo à flexibilidade, agilidade, mudança e inovação.

\subsection{Considerações finais do capítulo 2}

Neste capítulo foi descrita a atuação dos administradores no atual ambiente competitivo, mostrando que os mesmos não possuem uma rotina fixa de trabalho, e lidam com problemas não estruturados e variados, por estarem constantemente respondendo a estímulos. Foi mostrado que o trabalho administrativo é basicamente decisório, que o administrador necessita de informações para a tomada de decisões, e que novas formas de estruturas organizacionais estão surgindo, visando decisões mais rápidas e eficientes. 


\section{Capítulo 3 - Qualidade da informação}

\subsection{Considerações iniciais}

Neste capítulo, são expostos os conceitos tradicionais relacionados à qualidade, e os conceitos relacionados à qualidade da informação, mostrando como esta é dependente do usuário e de seu contexto de uso. Neste capítulo, também é caracterizada a informação útil ao administrador.

\subsection{Qualidade}

A palavra qualidade tem sido amplamente utilizada nas organizações nos últimos anos. Com o acirramento da competitividade, a busca pela qualidade tem norteado as organizações que lutam pelo sucesso, cujos programas de busca são constantes. O conceito de qualidade é abrangente, e vários autores o definem sob enfoques diferentes. ROBIC \& SBRAGIA (1996), trazem os conceitos de qualidade de alguns autores clássicos do assunto:

- segundo Juran: "A qualidade consiste nas características do produto que vão de encontro às necessidades dos clientes e, dessa forma, proporcionam a satisfação em relação ao produto";

- segundo Garvin: "São cinco os enfoques da qualidade: aspecto transcendental, adição de bons componentes, satisfação dos clientes, conformidade às especificações e valor";

- segundo Deming: "Qualidade é o resultado final da interação harmoniosa entre metas, sistemas e seres humanos";

- segundo Feingenbaum: “A qualidade é enfocada como um valor medido através do nível de organização de empresa";

- segundo Crosby: "Qualidade é conformidade às especificações".

A respeito dos múltiplos significados de qualidade, JURAN \& GRYNA (1991), colocam que o uso do conceito é dominado por dois significados:

- a qualidade consiste nas características do produto que vão ao encontro das necessidades dos clientes, e portanto, proporcionam a satisfação em relação ao produto;

- a qualidade é a ausência de falhas.

Para entender esses dois significados principais, os autores afirmam ser necessário definir várias palavras-chaves:

- produto: produto é o resultado de um processo. O produto é composto em diferentes graus por bens, software e serviços. Bens caracterizam-se pela tangibilidade: lápis, 
televisores, edifícios de escritórios. Softwares têm mais de um significado. O mais conhecido está associado a procedimentos lógicos para executar tarefas - como a confecção de programas de computadores. Outro, são as informações convenientemente organizadas, em geral: relatórios, planos, instruções, aconselhamento, roteiros. Serviços são os trabalhos executados para atender a terceiros. Indústrias inteiras são criadas para a prestação de serviços como geração e distribuição de energia elétrica, transportes, comunicações, diversões, etc.

- características do produto - característica é uma propriedade que um produto possui e que visa atender a certas necessidades do cliente. As características do produto podem ter natureza tecnológica - por exemplo, o consumo de combustível por um veículo, as dimensões de um componente mecânico, a viscosidade de um produto químico, a regularidade de tensão de fornecimento de energia elétrica. As características do produto podem assumir outras formas - por exemplo rapidez na entrega, facilidade de manutenção, cortesia do serviço.

- hierarquia das características do produto - os produtos são fabricados dentro de uma espécie de organização hierárquica ou piramidal. No topo da pirâmide tem-se o produto final ou sistema. Abaixo, têm-se várias camadas compostas por componentes, subsistemas, etc. Em cada camada, as características dos produtos devem ser definidas por meio de especificações e procedimentos. Na última camada, estão os vários pedaços do todo como tarefas de um procedimento, propriedade de materiais ou partes de uma peça. Para tais tarefas ou propriedade, as características do produto consistem em definições elementares tais como a temperatura do forno, o diâmetro do eixo. Tais características de produto são freqüentemente chamadas de características qualidade.

- cliente - um cliente é uma pessoa que sofre o impacto do produto. Os clientes podem ser externos ou internos.

- clientes externos - sofrem o impacto do produto, mas não fazem parte da companhia (ou de outra instituição) que o produz. Os clientes externos incluem os que compram o produto, órgãos reguladores do governo, o público (que pode sofrer o impacto exposto a produtos perigosos ou que causem danos ao meio ambiente), etc.

- clientes internos - dentro de uma empresa existem várias situações nas quais os departamentos ou as pessoas fornecem produtos uns aos outros. Os receptores são denominados clientes internos.

- usuários - são clientes que executam ações positivas com relação ao produto. Aqui incluímos as empresas que o compram como matéria prima para seus processos; os 
comerciantes que revendem o produto, e os consumidores, que fazem uso do produto em sua forma final.

- necessidades do cliente - todos os clientes têm necessidades que devem ser atendidas, e as características do produto têm esse objetivo. Isto se aplica tanto a clientes internos quanto a externos. No caso de clientes externos, a resposta determina a satisfação com o produto e, conseqüentemente, a facilidade de venda do produto. No caso de clientes internos, a resposta determina a competitividade de produção da empresa, a qualidade, etc, bem como o moral dos departamentos.

- satisfação com o produto - as características do produto, que atendem às necessidades do cliente, fornecem satisfação, fator decisivo para sua comercialização. Nos mercados competitivos, existem vários fornecedores de características de produtos. A variação resultante leva a diferentes graus de satisfação e às respectivas diferenças na participação de mercado dos fornecedores.

- grau-grau é um nome conhecido para os estados de satisfação com o produto, algumas vezes também chamado de qualidade do projeto. Os produtos cujas características preenchem as necessidades dos clientes em um grau superior são chamados de produtos de alto grau. Às vezes, esses graus são estabelecidos formalmente, como é o caso dos serviços de hotelaria ou dos cortes especiais de carne.

- conformidade com as especificações - também conhecida como conformidade com as necessidades. Algumas pessoas definem a qualidade como sendo a conformidade com alguns padrões, por exemplo, conformidade com as especificações, com os procedimentos ou necessidades. Tais definições podem auxiliar no esclarecimento da responsabilidade com a qualidade que têm os trabalhadores e superiores. Nesses níveis, a pessoa pode não ter um conhecimento total das necessidades dos vários clientes internos e externos; contudo, esses trabalhadores e supervisores, precisam de definições claras de suas responsabilidades no que diz respeito à qualidade.

- deficiência do produto - a segunda maior definição de qualidade é a ausência de falhas. As deficiências de um produto podem aparecer na forma de atraso de entrega, falhas em serviços, erros em faturas, sucata ou retrabalho e mudanças no projeto. Cada um desses casos é o resultado de alguma deficiência em um produto ou processo. Todos causam transtorno aos clientes.

- insatisfação com o produto - como conseqüência das deficiências do produto tem-se o cliente insatisfeito. Os clientes externos expressam essa insatisfação na forma de reclamações, devoluções ou queixas. Se a resposta a essa insatisfação é inadequada, ou a extensão da insatisfação é muito grande, o cliente externo pode parar de comprar o 
produto. Essas reações por parte dos clientes externos atingem o fornecedor através da combinação de vários fatores como a diminuição nas vendas, custos aumentados, entregas atrasadas, baixa produtividade, etc. As deficiências do produto podem atingir também os clientes internos. Estes expressam sua insatisfação na forma de reclamações internas. Se a resposta não for adequada ou o nível de insatisfação for muito alto, as conseqüência serão: deterioração da cooperação entre os departamentos, acusações mútuas, moral baixo etc. Tais conseqüências contribuem para diminuir as vendas, aumentar os custos, diminuir a pontualidade nas entregas, diminuir a produtividade, etc.

- disponibilidade - a continuidade da vida, numa sociedade industrial, depende exclusivamente da continuidade dos serviços de suprimento de energia, comunicações, transportes, água, etc. Para garantir essa continuidade, foram empregados grandes esforços a fim de se descobrir como minimizar a incidência de falhas nos produtos e como restabelecer os serviços prontamente em caso de interrupção dos mesmos. Um dos elementos ligados a esses esforços tem sido o reconhecimento da continuidade do serviço, como um parâmetro de adequação ao uso, e o estabelecimento de avaliações desse parâmetro recebeu o nome de disponibilidade. Ele está relacionado ao tempo e pode ser medido pela extensão na qual o usuário pode ter o serviço assegurado quando ele precisar.

- confiabilidade - se um produto nunca falhou, sua confiabilidade é de $100 \%$. Porém os produtos falham, de modo que um subparâmetro essencial da disponibilidade é o índice de falhas, para o qual o termo técnico aceito é confiabilidade. A definição clássica para o termo, feita por AGREE (1957) apud JURAN \& GRYNA (1991), é a probabilidade de um produto executar, sem interrupções, sua função específica sob determinadas condições e durante um tempo determinado. A confiabilidade é amplamente determinada pela qualidade do projeto. Quando ela é atingível, inerente ao projeto, é chamada de confiabilidade intrínseca. Entretanto, a confiabilidade atingida é geralmente menor, em virtude de condições ambientais não previsíveis que surgem durante o uso, lapsos na qualidade da conformidade, manutenção inadequada, etc.

Os mesmos autores citam outras definições de qualidade:

- Padrão A3-1987 da American National Standard Institute/American Society for Quality Control (ANSI/ASQC). Reconhece os significados múltiplos da palavra qualidade. O significado adotado para o padrão é: "A totalidade das características de um produto ou serviço, relacionados com sua habilidade em satisfazer às necessidades implícitas ou declaradas". 
- O Glossário da Organização Européia para o controle da Qualidade (1981) apresenta a seguinte definição para qualidade: “A totalidade das características de um produto ou serviço, relacionadas com sua habilidade em satisfazer uma determinada necessidade. No que diz respeito à qualidade dos produtos manufaturados, ela é determinada principalmente pela qualidade do projeto e pela qualidade da fabricação".

- A Enciclopédia Soviética define qualidade da seguinte maneira: "qualidade de produtos, é o conjunto de suas propriedades que determinam sua habilidade em satisfazer às necessidades para as quais foi criado".

JURAN \& GRYNA (1991), quanto à definição de qualidade como sendo adequação ao uso, afirmam que esta conseguiu ampla aceitação, porém não universal.

\subsection{Qualidade da informação}

A informação pode ser assumida como um produto, resultante do processo que a produziu e assumindo perfeitamente, a fim de definir sua qualidade, os conceitos de qualidade trazidos pela literatura. Porém, além dos conceitos de qualidade tradicionais, a informação pode ser classificada como de qualidade ou não, de acordo com outros aspectos. STAIR (1998), define as características da boa informação, conforme mostra a tabela 10:

Tabela 10 - As características da boa informação - STAIR (1998)

\begin{tabular}{|l|l|}
\hline Característica & \multicolumn{1}{|c|}{ Definição } \\
\hline Precisa & $\begin{array}{l}\text { A informação precisa não tem erros. Em alguns casos, a informação } \\
\text { imprecisa é gerada pela entrada de dados incorretos no processo de } \\
\text { transformação. Isto é comumente chamado de entra lixo, sai lixo }\end{array}$ \\
\hline Completa & $\begin{array}{l}\text { A informação completa contém todos os fatos importantes. Por } \\
\text { exemplo, um relatório de investimento que não inclui todos os custos } \\
\text { não está completo }\end{array}$ \\
\hline Econômica & $\begin{array}{l}\text { A informação também deve ser de produção relativamente econômica. } \\
\text { Os tomadores de decisão devem sempre fazer um balanço do valor da } \\
\text { informação com o custo de sua produção }\end{array}$ \\
\hline Flexível & $\begin{array}{l}\text { A informação flexível deve ser utilizada para diversas finalidades. Por } \\
\text { exemplo, a informação de quanto se tem de estoque de uma } \\
\text { determinada peça pode ser usada pelos representantes de vendas no } \\
\text { fechamento de uma venda; por um administrador de produção para } \\
\text { determinar se mais estoque é necessário; por um diretor financeiro para } \\
\text { determinar o valor total que a empresa tem investido em estoques }\end{array}$ \\
\hline Confiável & $\begin{array}{l}\text { A informação confiável pode ser dependente. Em muitos casos, a } \\
\text { confiabilidade da informação depende da confiabilidade do método de } \\
\text { coleta dos dados. Quer dizer, a confiabilidade depende da fonte da } \\
\text { informação. Um boato vindo de fonte desconhecida que os preços do } \\
\text { petróleo devem subir, pode não ser confiável }\end{array}$ \\
\hline Relevante & $\begin{array}{l}\text { A informação relevante é importante para o tomador de decisões. A } \\
\text { informação de que os preços da madeira de construção devem cair, pode } \\
\text { não ser relevante para um fabricante de chips de computador }\end{array}$ \\
\hline
\end{tabular}


Tabela 10 - As características da boa informação - STAIR (1998)

\begin{tabular}{|l|l|}
\hline Simples & $\begin{array}{l}\text { A informação não deve ser exageradamente complexa. A informação } \\
\text { sofisticada e detalhada pode não ser necessária. Na realidade, } \\
\text { informação em excesso pode causar sobrecarga de informação, quando } \\
\text { um tomador de decisões tem informação demais e não consegue } \\
\text { determinar o que é realmente importante }\end{array}$ \\
\hline Em tempo & $\begin{array}{l}\text { A informação em tempo é enviada quando necessária. Saber a } \\
\text { condições do tempo da semana passada não ajudará a decidir qual } \\
\text { agasalho vestir hoje }\end{array}$ \\
\hline Verificável & $\begin{array}{l}\text { Finalmente, a informação deve ser verificável. Isto significa dizer que } \\
\text { se pode checá-la para saber se está correta, talvez até várias fontes da } \\
\text { mesma informação }\end{array}$ \\
\hline
\end{tabular}

Sendo qualidade um termo que assume vários significados, a definição de qualidade da informação tem significado até mais complexo, por ser ela um produto diferenciado. NEHMY \& PAIM (1998) afirmam que é difícil definir qualidade da informação, e, que quase sempre, tem sido feita sob pontos de vista de definições específicas e subjetivas, que levam a interpretações poucos claras, imperfeitas e de alguma forma, caóticas.

Segundo MARCHAND (1990) apud NEHMY \& PAIM (1998), uma das abordagens para a qualidade da informação, é a transcendente, que the confere valor universal e absoluto. Neste caso, a qualidade seria sinônimo de excelência, extratemporal e permanente, com características que se mantêm apesar das mudanças de gostos e de estilos. Neste mesmo sentido de valor absoluto, COONEY (1991) apud NEHMY \& PAIM (1998), refere-se à expressão qualidade intrínseca, quando aborda o atributo permanente da informação, afirmando que esta possui um valor intrínseco.

Porém, como visto em várias definições de qualidade, esta está sempre vinculada ao uso que o usuário faz dela, e ao contexto de utilização. Assim, segundo EATON \& BAWDEN (1991) apud NEHMY \& PAIM (1998), vários argumentos podem ser encontrados na literatura negando o valor real ou intrínseco da informação. Os autores afirmam que é impossível determinar o valor da informação, pois este depende do contexto e de sua utilização por usuários particulares, em ocasiões particulares. Continuando o mesmo tipo de afirmação, CONNEL (1981) apud NEHMY \& PAIM (1998), também nega o valor intrínseco da informação e o vincula ao usuário, afirmando que seu valor é inteiramente subjetivo. Afirma, ainda, que a informação não varia em valor por causa de suas características externas e sim pelo que está na mente do usuário. Ainda nesta mesma linha, MARCHAND (1990) apud NEHMY \& PAIM (1998), coloca que tipos e fontes de informação que mais satisfizessem o usuário torná-la-iam de melhor qualidade, e WAGNER (1990) apud NEHMY \& PAIM (1998), referindo-se às tendências dominantes sobre a qualidade da informação, afirma que vários estudos expressam que o valor da informação 
depende do usuário e do contexto de utilização, e, assim, somente o usuário pode julgar o valor ou qualidade da informação.

MARCHAND (1990) apud NEHMY \& PAIM (1998), a respeito de qualidade da informação baseada na produção, afirma que a qualidade seria vista como adequação a padrões estabelecidos pela necessidade de informação do consumidor. Desvios em relação aos padrões significariam perda de qualidade. $\mathrm{O}$ mesmo autor desagrega o conceito de informação em oito dimensões inter-relacionadas, e além de defini-las, comenta sobre cada uma delas, diluindo o poder de sua utilização como características descritivas, de acordo com a tabela 11:

Tabela 11 - Oito dimensões da qualidade da informação

MARCHAND (1990) apud NEHMY \& PAIM (1998)

\begin{tabular}{|l|l|}
\hline \multicolumn{1}{|c|}{ Dimensão } & \multicolumn{1}{c|}{ Definição / Comentários } \\
\hline Valor real & $\begin{array}{l}\text { Variabilidade da percepção do valor do produto (informação ou serviço), } \\
\text { dependentes de estilos individuais de tomada de decisão }\end{array}$ \\
\hline $\begin{array}{l}\text { Características } \\
\text { suplementares }\end{array}$ & $\begin{array}{l}\text { Utilidade básica de um produto ou serviço de informação. Faz um alerta } \\
\text { sobre os diferentes pesos que as características da informação podem ter } \\
\text { em contextos diversos de tomadas de decisão }\end{array}$ \\
\hline Confiança & Atitudes contraditórias de confiança em relação às fontes \\
\hline $\begin{array}{l}\text { Significado } \\
\text { no tempo }\end{array}$ & $\begin{array}{l}\text { Variabilidade da atualidade da informação em diferentes contextos de } \\
\text { tomadas de decisão }\end{array}$ \\
\hline Relevância & $\begin{array}{l}\text { Invoca as diferenças na percepção da relevância da informação entre } \\
\text { projetistas de sistemas e agentes de tomada de decisão }\end{array}$ \\
\hline Validade & $\begin{array}{l}\text { Variação da percepção da validade da informação, dependente de quem a } \\
\text { fornece e de como é apresentada. }\end{array}$ \\
\hline Estética & Subjetividade do aspecto estético da informação \\
\hline $\begin{array}{l}\text { Valor } \\
\text { percebido }\end{array}$ & $\begin{array}{l}\text { Irracionalidade da atribuição de reputação pelo usuário a sistemas de } \\
\text { informação }\end{array}$ \\
\hline
\end{tabular}

O autor complementa afirmando como é difícil descrever e medir a informação, e que os comentários feitos aos atributos da qualidade diluem a idéia de excelência nos vários fatores assinalados, e colocam em cena aquele que utiliza a informação, o usuário, como contraponto necessário a uma pretensa objetividade da noção.

OLAISEN (1990) apud NEHMY \& PAIM (1998), propõe um modelo onde os aspectos usuais da qualidade da informação são agrupados em quatro categorias, conforme mostra a tabela 12 :

Tabela 12 - Quatro categorias dos aspectos usuais da qualidade da informação

OLAISEN (1990) apud NEHMY \& PAIM (1998)

\begin{tabular}{|c|l|}
\hline Categoria & \multicolumn{1}{c|}{ Definição } \\
\hline Qualidade cognitiva & $\begin{array}{l}\text { Dependente de como a fonte é valorizada pelo usuário, } \\
\text { incluindo-se aqui aspectos como credibilidade, relevância, } \\
\text { confiança, validade e significado no tempo }\end{array}$ \\
\hline
\end{tabular}


Tabela 12 - Quatro categorias dos aspectos usuais da qualidade da informação OLAISEN (1990) apud NEHMY \& PAIM (1998)

\begin{tabular}{|l|l|}
\hline $\begin{array}{l}\text { Qualidade do desenho da } \\
\text { informação }\end{array}$ & $\begin{array}{l}\text { Incorpora fatores referentes à forma, flexibilidade e } \\
\text { seletividade }\end{array}$ \\
\hline Produto da informação & Valor real e abrangência \\
\hline Qualidade da transmissão & Definida pelo critério da acessibilidade \\
\hline
\end{tabular}

ZUCCHI (1999), aborda a informação contábil, mas apresenta afirmações que podem ser estendidas para informações de qualquer área. $\mathrm{O}$ autor afirma que a informação contábil, para ser útil, deve ter características específicas para atender a necessidade de seus usuários. $\mathrm{O}$ autor lista as seguintes características, entre outras, definidas pelo Financial Accounting Standards Board (FASB):

- relevância: capacidade de alterar uma decisão. Para isso, a informação deve ter:

- valor preditivo: deve ajudar os usuários a aumentarem a probabilidade de estimar corretamente os resultados dos eventos passados e presentes;

- valor de feedback: deve ter um importante papel na confirmação ou correção de expectativas, anteriormente formuladas;

- oportunidade: a informação deve ser disponibilizada antes que perca sua capacidade de influência o processo decisório;

- confiabilidade: deve ser livre de erro e representar de forma fidedigna ao que se propõe representar. Assim, a informação deve apresentar:

- fidedignidade: harmonia entre a medida e o fenômeno que se pretende representar;

- verificabilidade: capacidade de garantir que a informação represente aquilo que se pretende representar, e o método de mensuração escolhido foi utilizado de forma correta.

Segundo BATTAGLIA (1999), a informação está sempre ligada aos conceitos de pertinência e relevância:

- relevância: contato efetivo entre remetente e destinatário;

- pertinência: resposta adequada ao que foi demandado.

Sobre a qualidade da informação, SCHWUCHOW (1990) apud NEHMY \& PAIM (1998), expõe a proposição de que a eficácia de produtos e serviços da informação dependem da adequação a demandas do usuário. Segundo o autor, a eficácia de um sistema de informação é dependente da situação do usuário e da natureza do problema apresentado.

BATTAGLIA (1999) aborda a inteligência competitiva como forma das organizações conseguirem competitividade. $\mathrm{O}$ autor afirma que a inteligência competitiva é 
fundamentada em duas grandes bases: informação e velocidade de seu uso. A inteligência competitiva faz uso de diversos tipos e fontes de informação em uma velocidade muito grande para monitorar desenvolvimento de produtos, processos, serviços e posições de mercado. A transferência de informação está ligada à especificação de uma demanda, detalhada por quem vai usá-la, e é no momento do uso que lhe vai ser atribuído um valor. O uso da informação é determinado pela sua necessidade, sofrendo influência de seu demandante. Dessa forma, a informação não possui valor absoluto, mas um valor dependente do momento em que chega ao usuário. Só o uso pelos tomadores de decisão pode avaliar o real valor da informação. A informação deve ser adequada, já que sua vida útil é curta, pois com as mudanças que ocorrem, ela entra rapidamente em obsolescência, possuindo portanto, momento certo para sua existência, para sua aplicação e para seu uso. Se não for utilizada no momento correto, perde valor.

TOMIMORI (1999) apresenta o caso do Centro de Informação Tecnológica (Citec), do Instituto de Pesquisas Tecnológicas de São Paulo (IPT). O órgão é prestador de serviços de informação científica e tecnológica, e gerencia fatores como pertinência, oportunidade, precisão, uso otimizado e contextualização da informação, com o intuito de incrementar pesquisas de empresas brasileiras, pois a informação é um recurso tão importante para a empresa como os recursos humanos, financeiros e materiais. O autor cita outras características consideradas pelo órgão na disponibilização de informação: quantidade, conteúdo, qualidade, disponibilidade, organização, e utilização em tempo real, como subsídio à execução de projetos de desenvolvimento tecnológico com informações necessárias à agilização de processos decisórios.

BARRETO (1998) afirma que uma mensagem de informação deve criar conhecimento no indivíduo e em sua realidade e cita o objetivo da ciência da informação: criar condições para a reunião da informação institucionalizada, sua distribuição adequada para um público que, ao julgar sua relevância, a valorize para o uso com o intuito de semear o desenvolvimento do indivíduo e dos espaços que este habita. Assim, o objetivo da ciência da informação é permitir que o ciclo representado na figura 11, se complete e se renove indefinidamente:

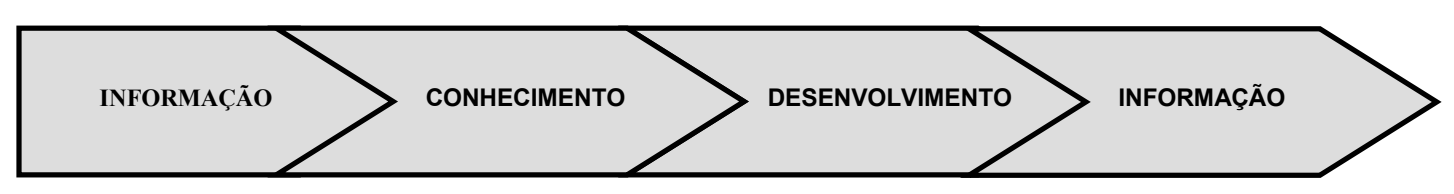

Figura 11 - Ciclo objetivado pela

Ciência da Informação - BARRETO (1998) 
Sobre este ciclo, o autor ainda afirma que, para que seu direcionamento esteja correto, sua velocidade deve ser compatível e seus espaços adequados.

MEYER (1997) coloca que o desenvolvimento da informática e das telecomunicações vem aumentando em muito o fluxo de informação para os gerentes, que não são capazes ou não querem processar tanta informação, causando problemas de gerenciamento. Uma pesquisa do autor sobre o uso de informações visuais (gráficos, figuras) pelos gerentes, revela que esta é considerada útil quando simplifica a resolução de problemas, aumentando a velocidade do processo e economizando tempo.

ROBBINS \& COULTER (1998), sobre excesso de informação, afirmam que a sobrecarga ocorre quando um indivíduo não pode processar a informação na mesma rapidez com que é recebida, e esta situação deve ser evitada. Neste mesmo sentido, ACKOFF (1988) afirma que um dos motivos para o baixo desempenho dos sistemas de informação desenvolvidos para gerentes, é o fato de que eles foram desenvolvidos com a premissa de que a necessidade crucial dos gerentes é ter mais informação relevante, mas o que eles precisam mesmo é de menos informação irrelevante. Estudos mostram que há excesso de informação e, quanto mais excesso, menos leitura, ou seja, quanto mais informações os gerentes recebem, menos eles usam.

MONTANA \& CHARNOV (1998) afirmam que as decisões baseadas em informações são tão boas, quanto a informação nas quais elas estão baseadas. Os computadores produzem uma quantidade grande de informação, mas o impacto da tecnologia não está na quantidade, mas na qualidade da informação produzida. As tomadas de decisão administrativas tornaram-se dependentes das informações, mas a produção indiscriminada de informações não promoverá a melhoria das decisões. Sendo a informação uma ferramenta gerencial usada por todos os níveis da organização, é necessário que ela satisfaça certos requisitos. Como qualquer ferramenta, ela deve ser apropriada para a tarefa. Deve ser também completa, precisa e entregue com pontualidade para ser útil. Se a qualidade da informação influi na qualidade da decisão, falhas na qualidade da informação podem levar a desastres organizacionais. $\mathrm{O}$ autor exemplifica: suponha que a administração vai tomar uma decisão com base no cara ou coroa. A probabilidade de acerto é de $50 \%$, ou seja, de 1 em 2. Porém, suponha que outra decisão deve ser tomada em seqüência. Sua probabilidade de acerto também é de 50\%. Porém, a probabilidade das duas serem corretas, é de $25 \%, 1 / 2 \times 1 / 2=1 / 4$. A probabilidade de se tomar uma série de decisões corretas é de $1 / 2$ elevado a $n$, onde $n$ é a quantia de decisões da série. Se alguém tiver que tomar 5 decisões em seqüência, a probabilidade de todas as decisões serem corretas é de 1/32. Isto mostra a importância das informações corretas para a tomada de decisão. O autor afirma que 
informação custa dinheiro, e adquirir e manter informações desnecessárias gasta recursos organizacionais, portanto os gerentes devem ser conscientes ao definirem suas necessidades de informação. Informações de menos ou de má qualidade não ajudarão na tomada de decisões; e informações em excesso dispendirão recursos e poderão causar a perda de informações úteis, atrapalhando as decisões.

CHIAVENATTO (2000b) diferencia conceitos constantemente confundidos: dado, informação e comunicação:

- dado - registro ou anotação a respeito de um evento ou ocorrência. Um banco de dados, por exemplo, é um meio de se acumular a armazenar conjuntos de dados para serem, posteriormente, combinados e processados. Quando um conjunto de dados possui um significado, tem-se uma informação;

- informação - conjunto de dados com significado, ou seja, que reduz a incerteza ou que aumenta o conhecimento a respeito de algo. Na verdade, informação é uma mensagem com significado para um determinado contexto, disponível para uso imediato e que proporciona orientação às ações, pelo fato de reduzir a margem de incerteza a respeito de nossas decisões;

- comunicação - quando uma informação é transmitida a alguém, sendo, então, compartilhada também por essa pessoa. Para que haja comunicação, é necessário que o destinatário da informação a receba e a compreenda. A informação transmitida, mas não recebida, não foi comunicada. Comunicar significa tornar comum a uma ou mais pessoas uma determinada informação.

MIRANDA (1999) também diferencia dado e informação, afirmando que dado é o conjunto de registros qualitativos ou quantitativos conhecido, que organizado, agrupado, categorizado e padronizado, adequadamente, transforma-se em informação. Já a informação é definida como sendo dados organizados de modo significativo, sendo subsídio útil à tomada de decisão. Nesta mesma linha, ALMEIDA (1995) coloca que um dado se transforma em informação quando ganha um significado para seu utilizador, caso contrário, continua sendo simplesmente um dado. Assim, a informação é um dado tratado. O autor afirma que um ponto essencial deve ser explorado nos sistemas de informação: a filtragem do grande volume de dados existente nos bancos de dados da empresa, e fornecer somente a informação necessária ao tomador de decisão.

ROBBINS (2000) utiliza uma biblioteca para fazer uma analogia entre dados e informações. Uma biblioteca com grande número de volumes não será muito útil aos usuários, a menos que estes possam encontrar rapidamente aquilo que desejam. Os volumes armazenados são os dados, que só se transformam em informação quando o usuário encontra 
o que deseja no momento em que deseja. Assim, o autor afirma que nas empresas, não há carência de dados, mas há carência de processamento destes dados, de forma que a informação certa esteja disponível à pessoa certa quando necessário.

DALFOVO et al. (1999) também diferenciam dado e informação, porém já no contexto organizacional:

- dado é um elemento que mantém a sua forma bruta (texto, imagens, sons, vídeos, etc.), ou seja, ele sozinho não ajuda a compreender determinada situação

- informação é esse mesmo dado, porém trabalhado pelo executivo, o que permite tomar certa decisão diante de qualquer situação. Em outras palavras, informação é o dado cuja forma e conteúdo são apropriados para um uso específico.

$\mathrm{O}$ autor afirma que o conhecimento adquirido durante esse processo para determinada situação é o que distingue dado de informação. De nada adianta uma sobrecarga das informações ou um sistema de bancos de dados abarrotados das mesmas, pois esse acúmulo poderá levar a empresa à desinformação. Um sistema de informação deve apresentá-las claramente, sem interferência de dados que não sejam importantes, e possuir alto grau de precisão e rapidez para não perder sua razão de ser em momentos críticos. Além disso, a informação deve sempre chegar a quem tem necessidade dela.

A figura 12 ilustra a diferença entre dados e informações:

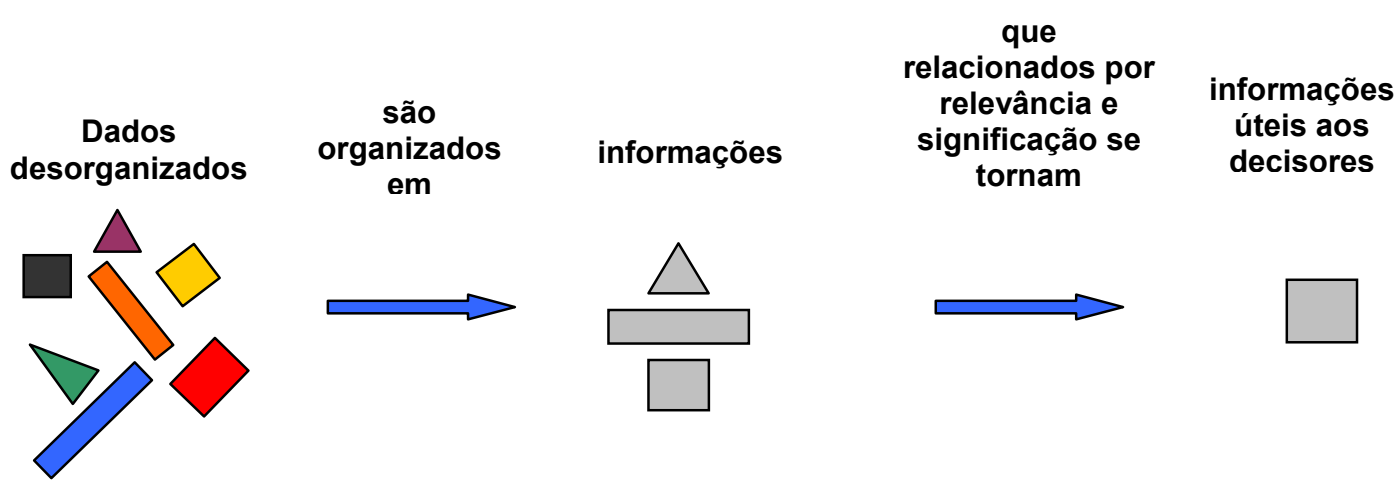

Figura 12 - Dados e Informações (ROBBINS 2000)

\subsection{A informação útil ao trabalho administrativo}

Sendo a qualidade da informação, dependente do uso e do contexto ao qual ela está inserida, somente o usuário pode definir se uma informação é útil ou não. No ambiente organizacional, muita informação é produzida e transmitida. Sistemas de informação são concebidos com o intuito de auxiliar os administradores, tomadores de decisão, a 
desempenharem melhor seu trabalho. Porém, somente os próprios administradores podem afirmar se as informações detidas por eles, são úteis ao desempenho de seus trabalhos.

EPSTEIN (1988), afirma que informação é uma redução de incerteza, oferecida quando se tem resposta a uma pergunta. A incerteza refere-se à quantidade de respostas possíveis que se conhece, apesar de não se saber qual delas é verdadeira. Segundo o autor, para se definir informação, no sentido de sua teoria, é necessário conhecer-se o tamanho da ignorância, isto é, a dimensão da classe das respostas possíveis. Quanto maior a probabilidade de ocorrência das respostas corretas, menor será sua redução de incerteza e vice-versa. A informação (I) pode ser vista como a diferença entre suas incertezas, I $=\mathrm{S}$ $(\mathrm{P} / \mathrm{X})-\mathrm{S}\left(\mathrm{P} / \mathrm{X}^{\prime}\right)$, onde $\mathrm{S}$ é a incerteza associada à pergunta $\mathrm{P}$ e ao conhecimento $\mathrm{X}$ que já se possui sobre a resposta possível. O conteúdo de uma nova mensagem pode produzir um novo conhecimento $X^{\prime}$ que por sua vez altera o grau de incerteza sobre a pergunta P.

Assim, se a incerteza se referir ao resultado de um jogo de dados, onde ela existe sobre 6 resultados possíveis, a informação $X^{\prime}$ de ter dado número par reduz esta incerteza para 3 resultados possíveis. O conteúdo informacional de uma mensagem é a medida da mudança de incerteza do receptor antes de receber a mensagem, para depois de recebê-la. Em geral, pode-se dizer que a incerteza de uma questão aumenta com o número de respostas alternativas.

A figura 13 ilustra a redução de incerteza provocada pela informação, onde as várias alternativas, presentes no primeiro momento, são reduzidas para apenas duas no segundo:

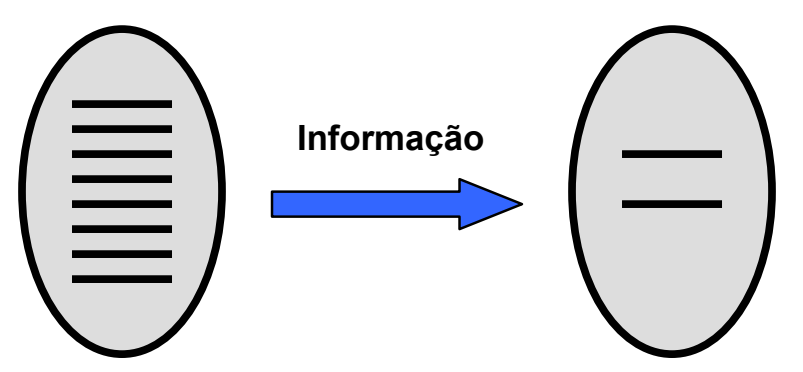

Figura 13 - Redução de incerteza causada pela informação

No ambiente organizacional, cada vez mais mergulhado em turbulência, a incerteza é uma constante, e o número de respostas alternativas é crescente. Sendo a informação a redução de incerteza diante das alternativas colocadas, a informação útil, ao trabalho administrativo, será aquela que mais reduzir incertezas, ou seja, aquela que apontar a alternativa correta ou eliminar o máximo das incorretas.

CHIAVENATTO (2000b), também aborda a informação como sendo redutora da incerteza. Segundo o autor, o conceito de informação, tanto do ponto de vista popular como 
do ponto de vista científico, envolve um processo de redução de incerteza. Na linguagem diária, a idéia de informação está ligada à de novidade e utilidade, pois informação é o conhecimento disponível para uso imediato e que permite orientar a ação, ao reduzir a margem de incerteza que cerca as decisões cotidianas. Na sociedade moderna, a importância da disponibilidade de informação ampla e variada cresce proporcionalmente ao aumento da complexidade da própria sociedade.

O autor afirma que o valor da informação está no seu poder de redução de incerteza, e que a informação é tanto maior quanto mais possibilidades forem excluídas. Como exemplo, o autor apresenta a frase: "as maçãs são vermelhas", e afirma que esta contém mais informação do que a frase "as maçãs são coloridas", pois na primeira, o substantivo exclui o que não é maçã e o adjetivo exclui todas as cores que não são vermelhas. LUCAS (1997) também define informação como uma entidade que serve para reduzir incertezas sobre algum estado ou evento.

ROBIC \& SBRAGIA (1996), sobre a definição de qualidade em projetos de informatização, colocam que esta deve basear-se necessariamente em:

- se o cliente especifica suas necessidades precisamente, então qualidade (ou sucesso do projeto) significa aderência às especificações;

- se o cliente define o que o produto deve fazer, deixando ao analista do sistema a determinação das especificações, então qualidade (ou sucesso do projeto) significa adequação ao uso;

- se houver uma investigação e discussão entre o analista do sistema e o cliente, chegando-se a um entendimento, então qualidade (ou sucesso do projeto) significa aderência às especificações acordadas como cliente.

Fica claro, segundo estes autores, que a informação útil aos administradores será somente aquela que eles desejam. A informação que não atende aos requisitos informacionais dos administradores é de má qualidade e de pouca ou nenhuma utilidade.

ALVIM (1998) coloca que, hoje, a busca deve ser por qualidade e não por quantidade de informação, e que o importante é possuir informação adequada às necessidades, no tempo esperado e a um custo compatível. Assim, o foco em ouvir a demanda, para depois se prestarem serviços de informação, acarreta ajustes nas estruturas formais das unidades e sistemas de informação atualmente em uso. A pregação dos especialistas em qualidade é muito bem vinda, quando afirmam a máxima de atender às necessidades dos clientes. No ambiente da sociedade moderna, onde o acesso à informação tornou-se um diferencial para o sucesso, o atendimento à demanda informacional deve ser na velocidade e nos meios compatíveis. 
ANTUNES \& OLIVEIRA (1998) afirmam que o mundo moderno não é estático, já que os avanços tecnológicos atuais estão obrigando as empresas, produtos e serviços a mudanças e adaptações em velocidade sem precedentes. Com a transformação da sociedade industrial em sociedade da informação, esta, como recurso estratégico, passa a ser imprescindível.

ALBRECHT (1999), coloca que, após os esforços para aperfeiçoamento da qualidade do produto e da qualidade do serviço, é preciso unir forças para melhorar a qualidade da informação, e que os prejuízos resultantes de informações erradas podem ser enormes. $\mathrm{O}$ autor surpreende-se com o paradoxo de estarmos na era da informação e pouco se falar a respeito dos custos elevadíssimos resultantes dos defeitos ou erros de manipulação das informações. Acrescenta ainda, que o problema da qualidade da informação é um gigante adormecido, cujas conseqüências podem fazer com que os efeitos da qualidade de produtos e serviços pareçam ínfimos.

STAIR (1998) afirma que, em todas as organizações, os sistemas de informação possuem importância fundamental e crescente. Se um pessoa pretende ter sólido conhecimento de como uma organização funciona, ela deve entender o papel dos sistemas de informação nesta organização. Com o acirramento da competitividade no ambiente de negócios, o autor coloca que assuntos e decisões de negócios estão tornando-se mais complexos, e que a compreensão dos sistemas de informação ajudará os gerentes a enfrentarem, se adaptarem e prosperarem neste ambiente desafiador.

WANDERLEY (1999) afirma que as experiências das empresas revelam que a busca por competitividade concorre para a crescente utilização de sistemas de informação que apóiem a tomada de decisão e assegurem a redução de tempo de resposta, diante das exigências do ambiente externo. A autora também aborda a inteligência aplicada aos negócios nas organizações. Ela afirma que inteligência é o resultado de um processo que começa com a coleta de dados, que posteriormente são organizados e transformados em informação, que, depois de analisada e contextualizada, transforma-se em inteligência. Esta, quando aplicada ao processo decisório, gera vantagens competitivas para a organização, conforme mostra a figura 14 :

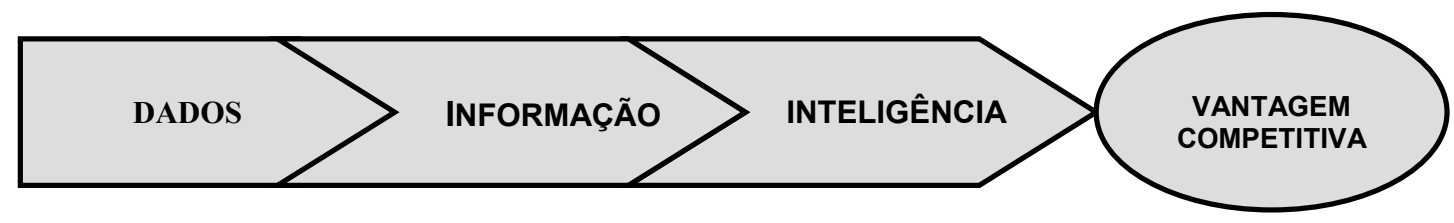

Figura 14 - Dos dados à vantagem competitiva - WANDERLEY (1999) 
Segundo HERRING (1997) apud WANDERLEY (1999), um sistema de inteligência de negócios é o processo organizacional que coleta sistemicamente a informação, analisa-a e dissemina-a como inteligência aos usuários para que possam tomar ações a partir dela. Segundo TYSON (1997) apud WANDERLEY (1999), o sistema de inteligência de negócios é como um quebra cabeças, onde com uma peça isolada, não se pode imaginar a figura a ser formada, mas ao juntarem-se as peças, vê-se a figura por inteiro, sendo muito útil aos decisores nas análises de situações.

ROBBINS \& COULTER (1998) afirmam que os administradores precisam de informações para controlar a organização. Sem informação, seria difícil realizar o processo administrativo de forma satisfatória, pois ela é um recurso vital. Segundo os autores, os administradores precisam de informações para:

- medir o desempenho atual da empresa;

- comparar o desempenho com os padrões planejados;

- preparação de faixas de variação aceitáveis dentro dessas comparações;

- desenvolvimento de cursos de ação apropriados;

Autores como HAMPTON (1990), MINTZBERG (1995), EHRLICH (1996), URIS (1989), apud BISPO \& CAZARINI (1998), BISPO \& CAZARINI (1998) e CHIAVENATTO (2000b), afirmam que um fato importante na tomada de decisão, é a obtenção de informação. BEUREN (1998), declara que quanto maior for a sintonia entre as informações fornecidas e as necessidades informativas dos gestores, melhores decisões poderão ser tomadas. GLAUTIER \& UNDERDOWN, apud BEUREN (1998), afirmam que no processo de tomada de decisão, uma das etapas é coletar todas as informações relevantes para as alternativas de solução. Dessa forma, é essencial que os gestores disponham das informações desejadas no momento desejado.

Segundo ROBBINS (2000), a qualidade de toda decisão depende muito da qualidade da informação à disposição do gerente. Na complexidade do mercado atual, em que a habilidade para tomar decisões rápidas e inteligentes é uma necessidade absoluta para a sobrevivência, o controle da informação tem adquirido importância significativamente maior.

MONTANA \& CHARNOV (1998) afirmam que a primeira etapa do processo de decisão, é a análise da situação para a verificação do problema, e esta análise é feita através do exame dos dados disponíveis. Os autores definem que gerentes diferentes tomam decisões diferentes, cada uma delas requerendo informações diferentes, e as necessidades de informação mudam em resposta aos desafios de tomada de decisão gerencial em ambientes de negócios que passam por mudanças rápidas. Assim, os sistemas de informação, também 
devem mudar, para que não sejam colocados em risco e também não comprometam a própria organização. O ritmo rápido dos negócios atuais exige atenção constante. Tomar decisões críticas baseadas em dados ruins podem assegurar fraco desempenho.

DALFOVO et al. (1999) afirmam que, com a rápida evolução e as mudanças tecnológicas, é fundamental que os executivos tenham grande versatilidade em suas decisões, mas para isso é necessário que tenham em mãos informações precisas e atualizadas. FIGUEIREDO (1998) afirma que possuem vantagem as organizações, cujas pessoas responsáveis pela tomada de decisão estratégica, conseguem fazer um trabalho correto e rápido. DALFOVO \& GRIPA (1999) com as rápidas mudanças e evolução tecnológica, afirmam que é fundamental que os empresários tenham grande versatilidade em suas decisões, mas para isso é necessário que tenham em mãos informações precisas e atualizadas. Segundo DALFOVO (1998) apud DALFOVO \& GRIPA (1999), se o executivo não utiliza informações como recurso estratégico, pode administrar por impulsos ou levado por modismos.

Segundo ARANTES (1995) apud SILVA (1998), a informação é um recurso fundamental na definição dos objetivos e rumos para a empresa; na fixação das estratégias e políticas; na avaliação e decisão sobre as alternativas de expansão e investimentos necessários; na avaliação dos resultados de negócio, verificando se estão de acordo com os rumos e objetivos definidos.

Conclui-se que a informação útil ao trabalho administrativo é somente aquela desejada pelo administrador, que chega no momento e no formato desejados. Sendo a qualidade da informação relativa e não absoluta, ou seja, dependente do usuário, só o administrador tem condições para avaliar quais informações lhe são úteis ou não. Os demais profissionais da organização, incluindo-se aí, os profissionais de informática, freqüentemente preocupam-se em passar mais e mais informações aos administradores, obviamente pensando que os estão ajudando. Porém a informação em excesso é tão prejudicial quanto a falta de informação. Somente o próprio administrador, usuário da informação, tem condições de julgar o seu valor. No atual ambiente competitivo, as situações e estímulos são altamente variáveis, requerendo informações também variáveis. Assim, somente a pessoa inserida nesta situação, que faz uso das informações, pode julgar a utilidade ou não destas.

\subsection{Considerações finais do capítulo 3}

Neste capítulo, foram expostos os conceitos tradicionais relacionados à qualidade, e os conceitos relacionados à qualidade da informação, mostrando como esta é dependente do usuário e de seu contexto de uso. Também foi caracterizada a informação útil ao 
administrador. Ficou claro que, no ambiente organizacional, somente o administrador, que faz uso das informações, para cada situação específica, tem condições de julgar a qualidade destas. 


\section{Capítulo 4 - A desconexão entre usuários e desenvolvedores}

\subsection{Considerações iniciais}

Neste capítulo, são abordados os benefícios esperados pelas organizações ao investirem em tecnologia da informação. Em seguida, é mostrado que nem sempre estes investimentos produzem os retornos esperados, e que reclamações dos administradores são constantes. Como problema da tecnologia da informação nas organizações, é apresentada a desconexão entre usuários e desenvolvedores de sistemas de informação.

\subsection{A tecnologia da informação nas organizações}

Pelo contexto exposto nos capítulos anteriores, verifica-se que a informação tem seu valor elevado para as organizações no atual ambiente concorrencial, e quanto melhor estas gerenciarem suas informações, maiores serão as chances de sucesso. Com este objetivo, a tecnologia da informação é amplamente utilizada.

O conceito de tecnologia da informação pode ser bastante abrangente. ALBERTIN (1999), afirma que a definição que considera os vários conceitos, e que acredita ser o mais adequado, é que tecnologia da informação é tudo aquilo com que se pode obter, armazenar, tratar, comunicar e disponibilizar a informação. O autor afirma que os investimentos em tecnologia da informação são significativos para as organizações cuja pretensão é atender a uma ampla relação de objetivos gerenciais, e coloca que, através desses investimentos, a gerência espera influenciar o desempenho da organização de diversas maneiras, tais como:

- prover uma vantagem competitiva, permitindo respostas rápidas às mudanças de mercado;

- prover informação necessária, acurada e no tempo para permitir melhor tomada de decisão;

- reduzir o custo de fazer negócio, substituindo capital por trabalho freqüente e automatizando as transações da empresa;

- permitir à empresa competir em mercados que requerem tecnologia específica;

- permitir flexibilidade tal que as empresas possam atender a uma ampla relação de necessidades dos clientes sem incremento de custos;

- prover uma plataforma tecnológica para permitir que outros sistemas de negócio sejam produzidos.

$\mathrm{O}$ autor prossegue afirmando que, se determinada organização tem uma quantidade de informações consideravelmente grande, e se esta quantidade tende a crescer, conforme aumenta o tamanho e a complexidade do negócio, suas necessidades de tratamento também 
crescerão. Assim, torna-se claro a necessidade de utilização da tecnologia da informação para que as organizações consigam dar um tratamento satisfatório às suas informações e, conseqüentemente, para que seus administradores tenham a possibilidade de utilizá-las corretamente em seus trabalhos.

STAIR (1998), cita entre outros, os benefícios esperados pelas organizações ao implantarem sistemas de informação:

- valor agregado aos produtos (bens e serviços);

- maior segurança e precisão;

- vantagens competitivas;

- produtos de melhor qualidade;

- aperfeiçoamento das comunicações;

- maior eficiência e produtividade;

- custos reduzidos;

- maior e melhor controle sobre as operações;

- tomadas de decisões administrativas superiores;

VAZ (1999), coloca que, diante do valor fundamental que a informação possui para a administração no atual cenário concorrencial, a tecnologia da informação assume o papel incontestável de uma ferramenta importantíssima para agilizar a aquisição, o processamento e a divulgação da mesma dentro das organizações, possibilitando maior evolução, independência e obtenção de lucros.

GOLDBACH (1998), coloca que a informação é a única coisa que pode ajudar os administradores a gerenciarem as mudanças e assegurar a competitividade. $\mathrm{O}$ autor prossegue afirmando que os sistemas de informação para gestão corporativa, podem ajudar na facilitação do acesso e uso dos dados organizacionais e, portanto, possibilitando previsões e acompanhamentos. DALFOVO et al. (1999) afirmam que os sistemas de informação surgiram como uma forma de manter o executivo preparado, com visão integrada de todas as áreas da empresa, sem gastar muito tempo, ou requerer do mesmo um conhecimento aprofundado de cada área. Os sistemas de informação devem auxiliar o executivo no processo decisório, através da obtenção de dados e conteúdos relevantes.

ZUBOFF (1994) apud BRITO (1997), cita os motivos que, em geral, levam os administradores a investirem em TI:

- maior rapidez nas operações;

- redução de custos;

- aumento da continuidade (integração funcional, automação intensificada e resposta rápida); 
- melhora do controle (precisão, acuidade, previsibilidade, consistência, certeza);

- maior compreensibilidade (visibilidade, análise, síntese) das funções produtivas.

SILVA (1998) lista os desejos dos usuários aos utilizarem sistemas de informação:

- tempo de resposta curto;

- resultados corretos;

- aumento de produtividade no seu trabalho;

É quase impossível para uma organização, no atual ambiente competitivo, gerenciar todas as suas informações sem o auxílio da tecnologia da informação. As rotinas operacionais obrigatórias, por si mesmas, geram grandes quantidades de informações, tornando sua manipulação difícil e demorada. Ao mesmo tempo, estas informações devem ser passadas aos administradores para que estes possam desempenhar bem seu trabalho, decidindo os rumos da organização. Se este processo for totalmente manual, a demora e os erros cometidos comprometerão o desempenho da organização. Entra em cena, então, a tão anunciada tecnologia da informação, empregada largamente nas organizações com o objetivo de promover o acesso e manipulação rápidos e sem erros das informações. Com a aplicação desta tecnologia em suas organizações, os administradores teriam disponibilizadas as informações, tão necessárias e importantes à condução do negócio. Porém, em muitos casos, esta não é a situação encontrada. Vários autores abordam a insatisfação dos administradores com a tecnologia da informação aplicada em suas organizações.

Colocado sempre no topo das hierarquias organizacionais, os administradores deveriam receber todas as informações necessárias para controlar a organização como um todo, e os sistemas de informações, implantados nos vários departamentos, deveriam disponibilizar tais informações. Porém, nem sempre esta é a situação encontrada. Muitos administradores não recebem as informações necessárias e deixam de usar tais sistemas informatizados. A respeito deste fato, MINTZBERG (1986), afirma que, assumindo-se a posição do executivo como indivíduo colocado no topo de um sistema hierárquico regular, este deveria receber todas as informações importantes de um gigantesco e complexo sistema de informações. Porém constata-se, com evidência cada vez maior, que os gigantescos sistemas de informações não funcionam, os executivos não os usam mais.

ROBIC \& SBRAGIA (1996), afirmam que não existe uma relação clara entre investimento e retorno em sistemas de informações. Segundo os autores, observações e relatos de casos mostram que inúmeros projetos de sistemas são percebidos como fracassos, apesar de terem sido completados dentro do prazo e do orçamento e terem atendido a todas as especificações técnicas, previamente estabelecidas. Da mesma forma, outros projetos são considerados sucessos, mesmo tendo falhado no cumprimento de tais ítens. CALDAS \& 
WOOD (2000), classificam como verdadeiras panacéias administrativas, os imensos investimentos feitos por empresas de todo o mundo em sistemas integrados de gestão, e que, previsivelmente, muitas implantações não atendem às expectativas. Os autores prosseguem afirmando que não há dúvidas de que o gerenciamento efetivo da informação em uma organização pode ser hoje uma fonte de vantagem competitiva. Porém não há exemplos tão claros, e o potencial relacionamento entre tecnologia da informação e vantagem competitiva, em muitas organizações, é difícil de ser determinada.

BENSAOU \& EARL (1998), observam que, embora muitos executivos reconheçam a importância da tecnologia da informação, suas experiências usando-a como ferramenta estratégica de negócio é freqüentemente frustrante. Os autores listam 5 problemas apontados pelos próprios executivos:

- os investimentos em tecnologia da informação não são relacionados com a estratégia de negócios;

- o retorno financeiro dos investimentos em tecnologia da informação é inadequado;

- a tecnologia é empregada cegamente, sem objetivos definidos;

- as relações entre usuários e especialistas não é boa;

- os projetistas de sistemas não consideram as preferências e os hábitos de trabalho dos usuários.

TAURION (2000) afirma que os altos administradores adquirem receio dos investimentos em tecnologia da informação, pois tais investimentos nem sempre produzem resultados palpáveis. McGEE \& PRUSAK (1994) também abordam os contrastes entre os maciços investimentos em tecnologia da informação e os resultados obtidos. Segundo os autores, as necessidades de informação dos executivos não receberam atenção adequada, e é muito difícil encontrar organizações que tenham usado a tecnologia da informação de forma satisfatória.

BELLOQUIM (1999c), afirma que as reclamações dos executivos são constantes quanto aos enormes gastos com tecnologia da informação e a falta de retorno com a tão prometida competitividade, e, uma vez que estes definem os investimentos de suas empresas, as investidas em informática passam a ser vistas com desconfiança, pois eles constatam que o software custa caro, demora muito para ser implantado e depois acaba servindo, para absolutamente, nada. De acordo com GUNN (1993), a evolução da tecnologia da informação deixou desnorteados e apreensivos os executivos, pois estes não sabiam como se beneficiarem financeira e estrategicamente da tecnologia da informação, e passaram a 
encarar os sistemas de informação somente como mais um custo empresarial e não como ferramentas estratégicas para ganho de produtividade.

LEITE (1994) afirma que, com relação à área de informática, é grande a chance dos executivos afirmarem que se sentem confusos por falta de domínio técnico, e também que têm a sensação de ficarem para trás por não terem as informações necessárias à condução do negócio. EARL (1998) afirma que os executivos estão cansados com as crescentes despesas com informática, nem sempre compatíveis com os resultados, e que a incerteza sempre está presente nesse ambiente, onde os usuários não conhecem bem suas necessidades, as novas tecnologias apresentam riscos e a implementação está sempre cheia de surpresas. GROVER et al. (1998) afirmam que, mesmo com grandes e crescentes investimentos em informática, a associação entre eles e o aumento em produtividade não tem sido bem demonstrada, e muitas vezes estas associações têm sido contraditórias. Este paradoxo de produtividade pode criar um clima de incerteza entre os altos executivos ao decidirem sobre investimentos em informática.

BELLOQUIM (1997), apud SEGÓRIA (2000), afirma que desde o início dos tempos do desenvolvimento do software, há problemas de qualidade, que ainda não foram resolvidos, e que se agravam a cada nova geração tecnológica. Segundo SIEGEL (1990) apud SEGÓRIA (2000), em muitas organizações, os projetos são entregues muito além do tempo planejado e com o dobro do custo. De acordo com SEGÓRIA (2000), devido aos vários problemas apresentados pelos softwares, foi desenvolvido o Capability Maturity Model (CMM), com o objetivo de qualificar o estado de processo de software e definir ações para a melhoria deste processo. O CMM foi desenvolvido pelo Software Engineering Institute (SEI), Instituto de Engenharia de Software, sediado na Carnegie Mellon University (CMU), em Pittsburg, Pennsylvania, Estados Unidos. O SEI é um centro que tem por missão aprimorar a prática de Engenharia de Software. O CMM classifica as organizações em cinco níveis evolutivos de maturidade, cada nível com suas características próprias, apresentadas na tabela 13 abaixo, de acordo com PAULK et al. (1993a) apud SEGÓRIA (2000):

Tabela 13 - Níveis de maturidade do CMM

PAULK et al. (1993a) apud SEGÓRIA (2000)

\begin{tabular}{|l|l|}
\hline Nível CMM & \multicolumn{1}{c|}{ Características } \\
\hline 1) Inicial & $\begin{array}{l}\text { O processo de desenvolvimento é desorganizado e até caótico. Poucos } \\
\text { processos são definidos e padronizados e o sucesso depende de esforços } \\
\text { individuais e heróicos dos desenvolvedores. }\end{array}$ \\
\hline
\end{tabular}




\section{PAULK et al. (1993a) apud SEGÓRIA (2000)}

\begin{tabular}{|l|l|}
\hline 2) Repetitivo & $\begin{array}{l}\text { Os processos básicos de gerenciamento de projeto estão estabelecidos e } \\
\text { permitem acompanhar custo, cronograma e funcionalidade e é possível } \\
\text { repetir o sucesso de um processo já utilizado anteriormente. }\end{array}$ \\
\hline 3) Definido & $\begin{array}{l}\text { Tanto as atividades de gerenciamento quanto de engenharia do processo } \\
\text { de desenvolvimento de software estão documentadas, padronizadas, e } \\
\text { integradas em um padrão de desenvolvimento da organização. Todos os } \\
\text { projetos utilizam uma versão aprovada e adaptada do processo padrão de } \\
\text { desenvolvimento de software da organização. }\end{array}$ \\
\hline 4) Gerenciado & $\begin{array}{l}\text { São coletadas medidas detalhadas da qualidade do produto e processo de } \\
\text { desenvolvimento de software. Tanto o produto quanto o processo de } \\
\text { desenvolvimento são entendidos e controlados quantitativamente. }\end{array}$ \\
\hline 5) Otimizado & $\begin{array}{l}\text { O melhoramento contínuo do processo é conseguido através de um } \\
\text { feedback quantitativo dos processos e pelo uso pioneiro de idéias e } \\
\text { tecnologias inovadoras. }\end{array}$ \\
\hline
\end{tabular}

Segundo o SEI (1997) apud SEGÓRIA (2000), levantamentos referentes a 533 organizações, que reportaram seus resultados de avaliações realizadas desde 1992 até o final de 1996, revelam que $61,5 \%$ destas organizações são nível 1, como mostra a tabela 14 :

\section{Tabela 14 - Distribuição das organizações nos níveis do CMM}

\section{SEI (1997) apud SEGÓRIA (2000)}

\begin{tabular}{|c|c|c|c|c|}
\hline Inicial & Repetitivo & Definido & Gerenciado & Otimizado \\
\hline $61,5 \%$ & $23,3 \%$ & $13,1 \%$ & $1,7 \%$ & $0,4 \%$ \\
\hline
\end{tabular}

Segundo SEGÓRIA (2000), no nível 1 - inicial, o processo de desenvolvimento de software comporta-se como caixa preta, onde somente as entradas e os produtos finais são conhecidos com clareza. Os resultados tendem a depender diretamente de posturas individuais. Não há controle de requisitos e o cliente só os avalia na entrega do produto, além de não haver planejamento ou estimativas.

MELLO (1999) expõe que, quando existe a área de software interna, a qual atende às demais áreas da empresa, geralmente existe uma grande fila de espera e uma dificuldade de controlar o desenvolvimento terceirizado. Neste ambiente também não há clareza na especificação e pode haver conflitos entre as áreas. Neste mesmo sentido, CAMARGO (2000), afirma que os antigos departamentos de informática possuíam recursos limitados, onde as solicitações dos usuários provocavam as famosas filas de espera de trabalho. $\mathrm{O}$ autor completa que, neste ambiente, definia-se uma ordem de prioridades e, por mais que trabalhasse, sempre haveria muitos usuários insatisfeitos com suas posições na fila e com a atuação do departamento de informática. 
BELLOQUIM (1999a) descreve de maneira irônica a forma como as empresas tratam seus softwares. Segundo o autor, muitas empresas tratam seus softwares como paredes a serem pintadas: como elas não tem dinheiro nem tempo para empregar um bom pintor, pintam do jeito possível, e, se for preciso, amanhã pintam novamente. Essas empresas deveriam tratar seus softwares como crianças tratadas por pediatras: economizar no pediatra hoje pode levar a problemas futuros muito mais caros para resolver ou mesmo a doenças incuráveis.

FIELD (1998), em um levantamento realizado com empresas que haviam instituído um novo diretor de informática recentemente, percebeu que elas, em geral, apresentavam os seguintes problemas:

- diversidade de hardware e software, de difícil integração;

- falta de credibilidade da área de informática, entre os usuários e os demais diretores;

- falta de visão estratégica da área.

DOLL \& TORKZADEH (1998) escrevem que existe uma lacuna entre o potencial da informática e o real uso dela nas empresas. Estudiosos e profissionais do assunto concordam que o potencial da informática está na forma como ela é usada, e que sistemas podem ser usados de maneiras limitadas devido a trabalhos pouco especializados, resistência do usuário, falta de treinamento ou falta de delegação aos funcionários. BAJAJ \& NIDUMOLU (1998) afirmam que os investimentos organizacionais em sistemas de informação apresentam grandes riscos. Um dos riscos é a aceitação e conseqüentemente uso pelos usuários finais. Em muitos casos, os usuários estão insatisfeitos com os sistemas de informação, mesmo tendo eles, condições de melhorar o serviço.

PRAHALAD \& KRISHMAN (1999) colocam que a qualidade do software pode ser complicada porque as necessidades dos usuários variam muito. Um software deve fazer mais do que ter as especificações técnicas para velocidade, por exemplo; ele também deve ser de uso fácil e estimulante. Como as empresas buscam constantemente novas formas de conseguir competitividade, a demanda por novas aplicações no departamento de informática aumenta, e os técnicos trabalham sobre grande pressão, tornando-se uma das principais causas para a baixa qualidade dos softwares.

CALDAS \& WOOD (2000) afirmam que devido à diversidade de sistemas presente nas empresas, os sistemas integrados de gestão surgem como a solução perfeita: melhora a informação, a velocidade nas decisões, reduz custos e aumenta os lucros. Porém, nas implementações, as dificuldades aparecem: 
- consultores inexperientes, usuários despreparados, atrasos crônicos, e estouros de orçamentos;

- a empresa percebe que o sistema não se adapta às necessidades dos negócios, e o negócio tem que se adaptar ao sistema;

- após meses de energia gasta na implementação, decisões importantes foram adiadas, clientes começam a reclamar e acionistas ficam impacientes.

TREPPER (2000) afirma que a imagem que se tem da área de tecnologia da informação é que esta sempre está sobre uma onda de caos, que ameaça subjugar a todos, profissionais e usuários. $\mathrm{O}$ autor também afirma que, com muita freqüência, os profissionais da área de informática não são vistos como parte dos negócios, simplesmente porque a forma como se comunicam e seu comportamento não demonstram uma disciplina coerente. SCAGLIA (2000) descreve a estrutura dos tradicionais departamentos de informática, como sendo um local cheio de profissionais que falavam uma língua à parte, cheia de jargões e que achavam que os usuários estavam ali para atrapalhar sua vida de gênio da programação. $O$ autor afirma que esta estrutura fechada, centrada exclusivamente em seus processos e sem envolvimento com a empresa como um todo, não é viável nos dias de hoje.

HUMPHREY (2001) afirma que até hoje, em geral, os softwares apresentam problemas de custos, cronogramas e defeitos, trazendo uma série de inconvenientes para os usuários e uma enorme perda de tempo e de recursos. O autor afirma que existe hoje uma cultura de software implantada nas empresas, que é caracterizada devido ao seguinte comportamento dos gerentes de projetos:

- quando os engenheiros de software apresentam um cronograma, este é geralmente muito longo;

- quando se dá uma data aos engenheiros de software, esta nunca é cumprida;

- para cumprir uma determinada data, e necessário encomendar a tarefa para uma data anterior;

- para acelerar o trabalho, faça os engenheiros de software trabalharem mais;

- até se chegar aos testes, não se pode dizer como o projeto está;

- como todos os programas tem defeitos, entregue assim que rodar;

- se os testes levam muito tempo, podem-se corrigir os erros mais tarde.

Segundo o autor, os engenheiros de software refletem, em geral, a mesma cultura, por apresentarem o seguinte comportamento e a seguinte crença:

- gerentes estabelecem cronogramas impossíveis;

- $\quad$ se você dá ao gerente uma data, ele vai pedir uma data anterior; 
- gerentes se dizem preocupados com a qualidade, mas só se preocupam com o cronograma;

- estão cansados de horas extras e desejam um trabalho normal;

- nunca atendem as datas estabelecidas, logo o cronograma não tem importância;

- não é possível planejar o trabalho criativo, e processos restringem a criatividade;

- sabem como o programa funciona, logo podem pular a etapa de projeto e codificá-lo;

- os softwares não necessitam de inspeção, pois fizeram certo desta vez;

- corrigem os erros na compilação, e depois testam ;

- $\quad$ se possuem agora poucos defeitos, logo terminarão os testes em poucos dias;

- se não podem encontrar todos os defeitos, eles os corrigirão depois.

O autor afirma que, mesmo parecendo visões extremas, é assim que a comunidade de software se comporta.

Neste mesmo sentido, LEITE (1994) afirma que quando uma empresa trabalha com uma equipe interna de informática, ao definir um novo projeto, com custos e cronogramas, este geralmente não é levado a sério. A equipe de informática não assume isso como um compromisso real, e a direção da empresa age de forma no mínimo conivente. Provavelmente, o problema começa em uma cadeia de indisciplina e falta de compromisso. Por outro lado, os usuários de cada área tendem sempre a achar que a prioridade é seu próprio serviço, ao passo que as outras áreas não devem ter tanta pressa assim, e então, passam a pressionar. E a empresa, como um todo, também não é capaz de cumprir as prioridades que ela mesma definiu. Assim, mudanças de escopos e de prioridades são constantes, tornando difícil o atendimento das solicitações. Nesta situação, a área de informática toma suas decisões de atendimento de solicitações, com base em um desses três critérios:

- bom relacionamento pessoal: atendem-se os usuários mais amigos ou mais próximos;

- bom relacionamento com o poder: a prioridade vai para o lado que mais interessa manter como aliado político, ou para as áreas que não sejam politicamente interessante deixar insatisfeitas;

- charme de cada trabalho: faz-se primeiro aquilo que tem o apelo técnico mais atraente e desafiador para o pessoal de informática, sem discutir os méritos do trabalho em si.

A autora completa que, estes critérios, evidentemente não tem um mínimo de racionalidade ou objetividade, e não levam a empresa a lugar algum. Mesmo que a equipe 
interna consiga terminar o projeto sem muito atraso, ele provavelmente custará mais do que o valor originalmente orçado. E quando colocado em produção, é provável que haja uma explosão de custos, não tanto por erro de cálculo, mas principalmente porque os usuários solicitam mais e mais funções. Por mais disciplinada que seja a equipe interna de informática, é difícil controlar prazos, já que todas as áreas usuárias pressionam a mesma equipe para o atendimento dos vários problemas que surgem no dia á dia. Alguns anos após a implantação da informática na empresa, a tendência natural é que cerca de 75 a $80 \%$ do tempo e esforço dos analistas esteja comprometida com a manutenção de sistemas já desenvolvidos, e que não são raros os projetos com custo final 10 vezes maior do que o original.

STÁBILE \& CAZARINI (2000a) afirmam que o data warehouse, banco de dados integrado e específico para consultas, é sem dúvida uma ferramenta poderosa por consolidar as informações organizacionais em um formato único e específico para uso estratégico. MANNI \& DORSA (1998) citam os benefícios do data warehouse:

- aumento do tempo para análise e tomada de decisão;

- eliminação de tarefas operacionais como pesquisas necessárias à decisão;

- melhor confiabilidade das informações devido à integração dos dados transacionais;

- racionalização do fluxo de informações da empresa;

- padronização dos conceitos de negócio;

- democratização das informações sobre o negócio.

Se as empresas precisam do data warehouse para conseguir estes benefícios, concluise, então, que até hoje, elas não conseguiram utilizar corretamente suas informações. Ou seja, os sistemas de informação não cumpriram seu papel de fornecer informações de qualidade.

Vários outros autores abordam problemas relacionados à informática nas empresas e apresentam números que mostram bem estas situações.

BUCKHOUT et al. (1999) exemplificam os problemas da informática nas empresas, afirmando que a implantação dos sistemas integrados de gestão empresarial é problemática em todo o mundo, demanda muito tempo, é cara e não traz os benefícios de competitividade e redução de custos que promete. Segundo os autores, as estatísticas mostram que $70 \%$ dos casos não atingem as metas corporativas estabelecidas. O Standish Group, empresa especializada em pesquisa de mercado de software, pesquisou a implantação deste tipo de sistema em grandes empresas, e segundo os autores, o estudo revelou que estas implantações tiveram seus custos, em média, $178 \%$ mais altos; os cronogramas de implementação 
sofreram atrasos de $230 \%$, e a queda média em melhorias funcionais atingiu um déficit de $59 \%$.

KEIL \& MONTEALEGRE (2000) afirmam que muitos executivos envolvem-se tanto em um projeto e continuam investindo nele mesmo quando deveriam abandoná-lo. Estes executivos não percebem certos sinais de alerta ou não os interpretam corretamente. Ainda que seja um fenômeno generalizado, ocorre mais em projetos de informática, porque envolvem complexidade, riscos e incertezas. Estes tipos de projeto têm altos índices de fracasso, e parecem aumentar. Um estudo mostra que 30 a $49 \%$ de todos os projetos de informática apresentam este fenômeno.

TAURION (1998b) apresenta dados de um estudo do Standish Group, onde se constata que, $31 \%$ dos projetos de informática são cancelados antes de chegarem ao fim, $53 \%$ estouram prazos e custos e apenas $16 \%$ cumprem prazo e orçamento. PENTEADO (1999b) afirma que são raras as empresas que checaram o retorno sobre investimento com sistemas integrados de gestão empresarial. De acordo com um estudo da empresa americana de consultoria e análise, Benchmarking Partners, três em cada quatro companhias que implantaram este tipo de software, estouraram o orçamento previsto ou cancelaram o projeto antes do fim. Outro estudo, apresentado pelo autor, é o do instituto de pesquisas Meta Group, que entrevistou 63 companhias entre as 500 maiores da revista Fortune, que já tinham seus sistemas de gestão empresarial bastante amadurecidos, com o intuito de verificar o retorno obtido, e descobriu que os números estão contra este tipo de sistema, pois nas empresas, após 5 ou 6 anos, o retorno em média, é de 1,5 milhão de dólares negativo. Ainda sobre sistemas integrados de gestão empresarial, E-BUSINESS confunde CEOs (2000) apresenta um estudo da empresa de consultoria A. T. Kearney, que entrevistou executivos chefes de empresas de todo o mundo. O estudo faz um levantamento do índice de satisfação com os sistemas integrados de gestão empresarial, onde em 2000, apenas $10 \%$ dos entrevistados afirmaram estarem muito satisfeitos, 59\% razoavelmente satisfeitos e $30 \%$ pouco ou nada satisfeitos.

DIA-A-DIA complicado (1999), apresenta uma pesquisa onde mais de 220 profissionais de informática foram entrevistados, para saber quais as questões que atrapalham o bom andamento dos trabalhos na área. Entre as questões, chamadas de pesadelos pela reportagem, foram levantadas:

- a falta de profissionais qualificados para assumir projetos definidos a fim de apoiar melhor os projetos da área;

- pressão da alta administração da empresa para apontar o retorno dos investimentos; 
- mudanças repentinas nas prioridades de negócio levando ao desvio do plano diretor de informática .

Sobre o cumprimento do plano diretor de informática, a pesquisa revelou os seguintes números:

- apenas 3,5\% dos entrevistados afirmaram que as definições dos planos estratégicos foram totalmente realizadas;

- pouco mais de $25 \%$ não concluíram nem $40 \%$ do que foi estipulado no plano;

- a maioria deles, cerca de $56 \%$ cumpriu entre $41 \%$ e $80 \%$;

FARRE (2001) apresenta alguns dados do estudo Chaos, do Standish Group, sobre projetos de informática:

- mais da metade dos projetos de desenvolvimento, levados a cabo nos EUA, atrasam e ultrapassam o orçamento;

- estes projetos acabam sendo realizados com menos recursos e funções do que originalmente especificados;

- quase um terço é cancelado durante o desenvolvimento.

\subsection{A desconexão entre usuários e desenvolvedores}

De acordo com WANG (1995), observa-se uma total desconexão entre a área de sistemas e os executivos das organizações. $\mathrm{O}$ autor explica que existe um desconhecimento total do que o outro lado fala: um fala em clientes, serviços de qualidade, concorrência, retorno sobre investimento e o outro fala somente sobre plataformas, computação cliente/servidor e orientação a objetos. Não existe integração, nem um vocabulário único. Esta desconexão é aceita e até defendida por ambos. Segundo o mesmo autor, muitos executivos chefes reconhecem que nem sempre foram cuidadosos ao comunicarem os objetivos estratégicos da empresa ao pessoal de tecnologia da informação. Outros só consultam a área de tecnologia da informação, após os terem formulado e outros não querem reconhecer que a tecnologia da informação ocupa papel central na realização dos objetivos organizacionais. $\mathrm{O}$ autor ainda acrescenta que as queixas entre os dois lados são constantes, pois os executivos chefes acusam os profissionais de tecnologia da informação de só se comunicarem em termos técnicos e de enfocar a tecnologia, não atendendo aos objetivos organizacionais. Já os profissionais de tecnologia da informação acusam os executivos de não compartilharem os objetivos estratégicos e tentarem minimizar a importância da área e a capacidade dos profissionais. 
Nesta clara disputa de poder e acusações, que somente prejudicam a empresa, conclui-se que os profissionais de tecnologia da informação, não desenvolveram habilidades empresariais, de comunicação e de relacionamento suficientes para gerenciarem bem seus projetos em busca dos benefícios organizacionais. Ainda, segundo o mesmo autor, esta desconexão afeta a qualidade dos sistemas de informações disponibilizados, pois quanto maior a ênfase ao usuário final, maior probabilidade de sucesso pela participação de quem realmente sabe de suas necessidades informacionais. Uma indicação clássica do egocentrismo da tecnologia de informação nas organizações e de sua falta de apoio aos objetivos finais, é a percepção do usuário de que ela age para obstruir e não para prestar assistência. Segundo MORAES (1998), apenas 65\% dos usuários tem autonomia para aprovar os sistemas que são desenvolvidos para eles mesmos. STERGIOU \& JOHNSON (1998) apud DALLAVALLE (2000a), afirmam que o "buraco" entre negócios e a tecnologia da informação, é o grande problema atual das organizações e dos sistemas. DALLAVALLE (2000b) escreve que, softwares inadequados são conseqüências de má definição de requisitos, causada pelo problema da comunicação entre desenvolvedores e usuários e a falta de conhecimento do domínio do sistema.

De acordo com BEUREN (1998), deve haver uma integração entre os modelos de decisão e as informações disponibilizadas, através da integração entre o sistema de informação e o sistema organizacional, e com o alinhamento das estratégias de negócio e a tecnologia da informação. Segundo a autora, a reduzida integração da área de sistemas com as áreas usuárias resulta na disponibilização de um conjunto de dados sem analisar se este satisfaz às necessidades do usuário.

DRUCKER (1996), sobre a desconexão entre usuários e desenvolvedores, coloca que muitos gerentes pensam que os especialistas em computador, sabem quais informações, eles, os gerentes, necessitam para realizarem seu trabalho e quais informações devem a quem. O autor ainda afirma que, na organização hoje, é preciso assumir a responsabilidade pelas informações, porque elas constituem a ferramenta principal. Porém, poucos sabem como usá-las. Poucos executivos sabem fazer perguntas do tipo: de que informações necessito para fazer meu trabalho? Quando preciso delas? De que forma? E de quem devo recebê-las? Praticamente ninguém pergunta: que informações devo passar? A quem? Quando? De que forma? Os especialistas em informação são fabricantes de ferramentas. Os usuários destas, sejam eles executivos ou técnicos, têm de decidir quais informações usar, para que e como. Eles precisam se tornar conhecedores de informações. Este é o primeiro desafio enfrentado pelos usuários de informações, agora que os executivos passaram a conhecer os computadores. Os executivos tornaram-se conhecedores de computadores. Os 
mais jovens chegam a saber mais a respeito de como funciona o computador do que a respeito da mecânica do automóvel ou do telefone. Mas poucos entendem de informação. Eles sabem como obter dados, mas ainda precisam aprender a usá-los.

SAVIANI (1998) aborda o relacionamento ruim que existe nas organizações entre a área de tecnologia da informação e as demais áreas. Segundo o autor, os usuários acusam os analistas de apresentarem soluções políticas previamente definidas e serem incapazes de priorizar seus requisitos de informação. Já os analistas acusam os usuários de apresentarem padrões irrealistas de trabalho, serem incapazes de transformar necessidades de informação num sistema útil, terem dificuldade de responder prontamente às mudanças de requisitos e nunca realizarem as atividades solicitadas dentro do prazo previsto. De acordo com o autor, os administradores de sistemas são ex-analistas seniores, que sempre administraram fluxos, máquinas e papéis, mas nunca pessoas. Ainda segundo o mesmo autor, o usuário deve ser responsável pela definição do que deve ser feito em termos de necessidades informacionais. O pessoal de sistemas deve apenas orientá-lo tecnicamente para que as informações necessárias sejam produzidas da melhor forma. O autor acrescenta que os sistemas informacionais, presentes nas organizações, não possuem nenhum compromisso com a decisão a ser tomada e são desenvolvidos sem visão estratégica. WHITAKER (1994) afirma que, em geral, desenvolvedores não são bons em lidar diretamente com o cliente. Em muitas apresentações de desenvolvedores a clientes, o autor afirma ter ficado impressionado com a inabilidade dos primeiros em comunicar expectativas de produto de forma apropriada.

GAUSE \& WEINBERG (1991) afirmam que uma razão que leva os usuários a se afastarem dos processos de projeto, é o fato de os projetistas os tratarem de forma padronizada. Os autores colocam que a maioria dos participantes é leiga somente com relação ao processo de desenvolvimento, mas perita em relação aos assuntos em que os projetistas são leigos, tornando sua participação necessária. Afirmam, ainda, que bilhões de dólares são desperdiçados todos os anos, fabricando-se produtos que não atendem aos requisitos, na maioria dos casos, porque os requisitos não foram entendidos de forma clara. Os autores declaram que conflitos geralmente ocorrem entre profissionais das diferentes áreas da empresa, podendo causar danos aos projetos, devido à redução das possibilidades para exploração de requisitos. Muitas vezes, as partes antecipam o conflito, por terem experimentado este tipo de situação anteriormente, e por ter sido desagradável e improdutiva, não querem experimentá-la conflito novamente. Não importa se são pessoas diferentes, em projetos e épocas diferentes, um lado começa o conflito antes que o outro lado possa começar. Neste mesmo sentido, BAJAJ \& NIDUMOLU (1998), concluem em seus estudos que existe uma grande relação entre as experiências anteriores dos usuários e a 
aceitação dos atuais sistemas, e PALVIA \& PALVIA (1999), mostram através de um estudo, que em empresas de pequeno porte, os fatores mais importantes na insatisfação dos usuários são o treinamento e educação.

LEITE (1994) afirma que os problemas apontados pelos executivos com relação à informática, são frutos de décadas de reinado absolutista dos tecnocratas dos centros de processamento de dados, aqueles sujeitos que se encastelavam numa sala de acesso proibido e fechavam-se em torno de sua própria realidade, definindo o que era e o que não era possível, forçando as prioridades, e estabelecendo os prazos, que geralmente eram muito longos. A autora não condena este tipo de profissional, pois ele era comprometido com a empresa e buscava dar o melhor de si, mas coloca que o problema é que eles tinham uma visão muito tecnocêntrica das coisas, faltando ligação com os objetivos do negócio da empresa. Neste contexto, segundo a autora, torna-se normal a situação de reféns dos executivos em relação ao pessoal técnico: não há como cobrar rigor ou como reclamar. Assim, pouco a pouco os executivos perderam o controle da situação. Neste mesmo sentido, GONÇALVES, J. L. M. (1999) afirma que os administradores adquiriram um sentimento de angústia e impotência frente ao departamento de informática, pois nunca conseguiram controlá-lo como queriam. Muitas vezes, o pessoal de informática apresenta propostas aos administradores, e estes, por se sentirem desconfortáveis ao lidarem com a informática, e também por sempre estarem ocupados, acabam confiando no pessoal da área.

Ilustrando o relacionamento ruim entre usuários e desenvolvedores, BRITO (1997) cita como um dos problemas do uso da informática nas empresas, a pouca importância atribuída a ela por parte de alguns gestores. Neste mesmo sentido, LEITE (1994) coloca que, em empresas que possuem equipes internas de desenvolvimento, o fornecimento de informações necessárias ao projeto, costuma ser tratado pelos usuários e demais envolvidos com um certo desdém, típico daquelas coisas que podem esperar.

FARRE (2001) apresenta alguns dados do estudo Chaos, do Standish Group, sobre projetos de informática. Como fatores desafiantes aos desenvolvedores de sistemas, o estudo aponta:

- falta de input de usuários;

- exigências incompletas ou mutáveis

- especificações e objetivos comerciais não muito claros.

$\mathrm{O}$ autor afirma que o software de qualidade deve se conformar às exigências do usuário, e o gerenciamento de exigências incompleto ou errôneo torna-se uma das grandes causas de falhas nos projetos de software. $\mathrm{O}$ autor cita uma empresa de consultoria, a Process 
Impact, onde seu consultor, Karl Miegers aponta os seguintes obstáculos como infestantes dos projetos de software:

- envolvimento inadequado do cliente;

- exigências vagas e ambíguas;

- construção de funcionalidades inúteis.

FARRE (2001) também afirma que a ampliação, para além das exigências iniciais, é preocupante, e normalmente ocorre quando as exigências não são atendidas no primeiro momento ou classes de usuários são esquecidas. Richard Washington, diretor de informática da Smart Online, empresa de software, afirma que os problemas são encontrados durante a avaliação de qualidade, quando o custo para resolução é maior, pois o código já está feito é a pressão para entregar é grande. Neste mesmo sentido, CAJADO (1999) afirma que problemas que são encontrados durante o uso, deveriam ter sido encontrados durante o desenvolvimento, diminuindo as surpresas dos usuários.

ALBERTIN \& MOURA (1995) realizaram um estudo entre instituições bancárias nacionais sobre suas áreas de informática. Os autores afirmam que as áreas usuárias alegam que os problemas referentes ao relacionamento com a informática se deve à sua distância da organização. Por outro lado, a informática também sente este problema, mas o atribui à falta de participação do usuário. Os dois lados consideram que a estrutura organizacional da informática é responsável por muitos de seus problemas de relacionamento e desempenho de atendimento.

AMARO (1999) afirma que o maior problema de todo projeto de sistemas está relacionado às etapas de especificações e testes, pois nas especificações são gerados $70 \%$ dos problemas em sistemas, uma vez que somente $60 \%$ das informações formais e informais são efetivamente documentadas, segundo informações do Quality Assurance Institute. Quanto aos testes, o problema é que, se houver algum atraso nas fases de um projeto de sistemas, aquela que normalmente é minimizada e comprometida é a de testes, que deveria ser a última a se comprometer, pois se trata da avaliação de todo esforço em gerenciamento e execução do projeto.

GOMES (1999) afirma que quando os objetivos para o desenvolvimento de sistemas não são claros, as pessoas passam a deduzir e criar o produto dentro de suas próprias visões, levando a sistemas inadequados para a função do negócio a ser atendida e, conseqüentemente, à métricas falhas, gerando uma expectativa divergente entre o cliente e os técnicos, isto é, uma estimativa irreal.

MOREIRA, T. R. (1999) aborda pesquisas que mostram que a baixa qualidade é uma das principais razões por atrasos, e por quase $50 \%$ dos motivos de cancelamento de 
projetos. Outros dados apresentados pelo autor são que, quanto maior a pressão pelo sistema, maior o número de defeitos gerados, e quanto mais cedo descobrir-se os defeitos, melhor. $\mathrm{O}$ autor afirma que o retrabalho nas fases de construção e testes, um problema criado nas fases de requerimentos e especificações, pode custar de 50 a 200 vezes mais do que custaria para revolvê-lo na própria fase em que ele foi criado.

GAUSE \& WEINBERG (1991) apresentam o custo relativo de reparação de erros nas seis diferentes fases do desenvolvimento de um sistema, conforme a tabela 15 :

Tabela 15 - Custo relativo de reparação de erros GAUSE \& WEINBERG (1991)

\begin{tabular}{|c|c|}
\hline Fase em que se encontra & Proporção do custo \\
\hline Requisitos & 1 \\
\hline Projeto & $3-6$ \\
\hline Codificação & 10 \\
\hline Teste de Desenvolvimento & $15-40$ \\
\hline Testes de Aceitação & $30-70$ \\
\hline Operação & $40-1000$ \\
\hline
\end{tabular}

NAULT \& STOREY (1998) afirmam que uma chave determinante do sucesso dos sistemas de informação é a aderência do sistema ao problema ao qual ele dá apoio. BUCKHOUT et al. (1999) demonstram que as implantações de sistemas integrados de gestão, em grande parte dos casos, apresentam problemas e não oferecem o retorno esperado. Os autores afirmam que, na maioria das vezes, este sistema não reconhece, e portanto não capta, a eficiência organizacional dos processos que estão sendo automatizados. Os autores citam uma implementação que aumentou os custos de um processo para executar tarefas antes não necessárias. Ninguém se deu ao trabalho de perguntar se a empresa precisava mesmo daquele processo, e a diretoria só analisou a decisão tarde demais. PERAZO (1997) coloca que os usuários descrevem as regras de negócio e os analistas processam essas descrições, representando-as em telas e procedimentos. É nesta tradução que parte dos processos de negócio se perde. $\mathrm{O}$ autor afirma que não há possibilidade de transformar sistemas construídos dessa forma, em aplicativos flexíveis e adequados às mudanças rápidas dos negócios.

HUMPHREY (2001) descreve como os problemas surgem e são aumentados nos processos de desenvolvimento de software: os problemas começam com requisitos pobremente estabelecidos e vão aumentando pela falta de planejamento adequado. Sem planos ou medições do processo, os engenheiros de software não podem controlar o próprio trabalho, e os gerentes de projeto só podem exercer pressão sobre o cronograma. Em 
situações de muita pressão, os engenheiros muitas vezes fazem um projeto superficial, omitem revisões e inspeções e se apressam para os testes. Sem objetivos para qualidade ou medições, a etapa de testes torna-se o primeiro momento, onde engenheiros e gerentes consideram a qualidade. Infelizmente, com produtos de baixa qualidade, o tempo de teste será longo, impossível de prever, e os produtos, após testados, permanecem com muitos erros não detectados. Em software, como em qualquer outra tecnologia, para ter como resultado dos testes um produto com qualidade, é necessário colocar em teste, um produto com qualidade. A figura 15 ilustra a descrição do autor, e mostra que o os problemas começam com requisitos inadequados:

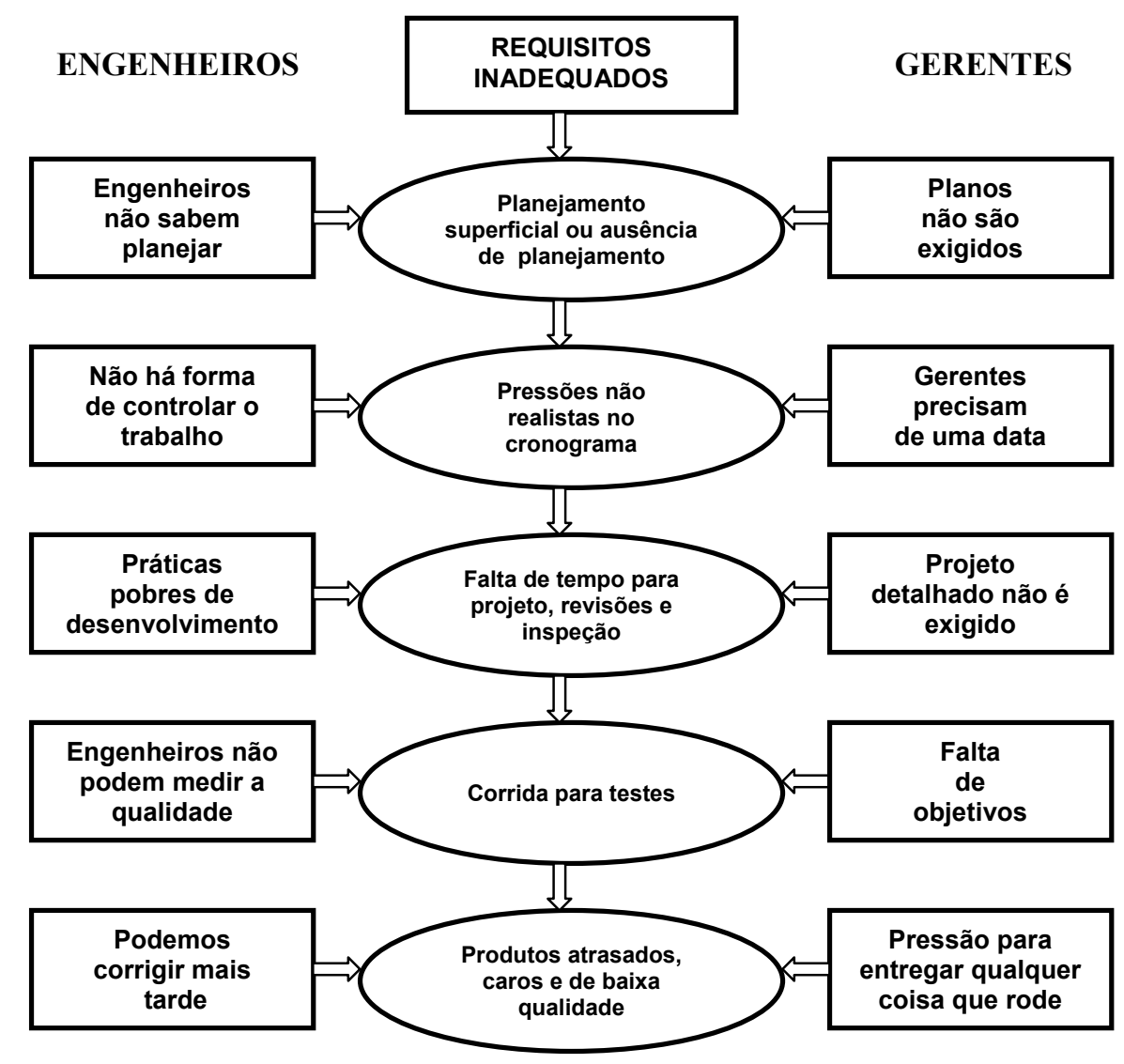

Figura 15 - Problemas do desenvolvimento de software - HUMPHREY (2001)

Através da literatura aqui revisada, percebe-se que muitos problemas, que deveriam ser encontrados no início do projeto, são encontrados apenas nas fases posteriores, quando os prejuízos são maiores. Isto ocorre devido a má especificação dos requisitos, causada, em grande parte, pela desconexão existente entre usuários e desenvolvedores. Esta desconexão entre as partes, tende a criar nas empresas os seguintes problemas relacionados à informática: 
- enfoque operacional dos sistemas de informação;

- enfoque tecnológico dos sistemas de informação

- diversidade de sistemas de informação.

Este três problemas são abordados na seqüência.

\subsection{Enfoque operacional dos sistemas de informação}

Os sistemas de informação tradicionais informatizam satisfatoriamente o nível operacional das organizações, mas deixam a desejar quando se referem às necessidades do alto escalão. Segundo TAURION (1998a), geralmente, um sistema aplicativo está focado na precisão dos processos operacionais. Os relatórios e informações destes sistemas, atendem perfeitamente aos usos operacionais, mas não são suficientemente utilizados pelos administradores e executivos. Assim, os sistemas de informações, tradicionalmente focados nos níveis operacionais das organizações, produzem informações relacionadas a este nível, e não atendem corretamente às necessidades informacionais dos níveis administrativos. Os relatórios e consultas, proporcionados pelos sistemas de informação tradicionais, são projetados para atender a problemas estruturados do nível operacional. Os usuários deste nível tem necessidades informacionais mais estáticas, e quando do desenvolvimento do sistema de informações, consultas e relatórios específicos para essas necessidades são projetados e implementados.

SAVIANI (1998), explica que os sistemas de informações sempre foram problemáticos para as empresas. $\mathrm{O}$ autor salienta, entre outros motivos, que estes sistemas sempre foram dirigidos a níveis inadequados na estrutura organizacional, e que seus projetos sempre foram considerados isoladamente. WANG (1995), compartilha desta afirmação, complementando que as informatizações departamentais operacionais são satisfatórias, porém sem comunicação com as demais áreas. OLIVEIRA (1996), considera três níveis de abordagens na abrangência de um sistema de informação administrativo: estratégico, tático e operacional. Cada um dos níveis tem influência no sistema quanto ao foco de análise. Quando se tem interesse pelo nível estratégico, toda a empresa deve ser considerada. Mais adiante se deve decompor os objetivos no nível tático, e por fim, detalhá-los ao nível operacional.

De acordo com STÁBILE \& CAZARINI (2000b), a grande maioria dos sistemas de informações nas organizações está focada isoladamente nos níveis operacionais, onde a informatização ocorreu mais cedo buscando informatizar procedimentos repetitivos. De acordo com ZUBOFF, apud STEWART (1998), a informatização dos processos 
operacionais das organizações apresenta duas faces distintas: a tecnologia da informação pode ser utilizada na automatização de operações seguindo uma lógica basicamente igual a dos sistemas de máquinas do século XIX, ou seja, a substituição do corpo humano por uma tecnologia que permite a realização dos mesmos processos com maior continuidade e controle. Por outro lado, a mesma tecnologia gera simultaneamente informações sobre as operações automatizadas, oferecendo um nível mais profundo de transparência para as mesmas. Assim, além de agilizar os processos operacionais das organizações, a tecnologia da informação produz uma vasta gama de informações a respeito destes processos. Estas, até pouco tempo atrás, eram desprezadas pelas organizações, que chegavam a reclamar dos problemas de armazenamento surgidos com o grande volume acumulado. Isto ocorria porque a informação sobre um processo operacional específico só tinha validade por pouco tempo ou enquanto este processo estivesse em curso.

JIANG et al. (2000) afirmam que um sistema de processamento de transações é projetado para manipular as atividades elementares e rotinas de transações da organização, sendo, na maioria, produtor de informação para outros sistemas, mas fundamental para o nível operacional, cujo principal propósito é responder questões rotineiras. CHEN et al. (2000), nesta mesma linha, afirmam que os sistemas de informações operacionais suportam as operações diárias dos negócios.

TEIXEIRA (1999) divide os sistemas de informação, de uma forma geral, em duas categorias:

- processamento de transações: sistemas que possuem como principal objetivo, o registro acurado das operações e fatos relevantes da área de negócio;

- suporte à decisão: sistemas projetados para apoiar os gestores na tomada de decisão, em um nível mais abrangente de prazo em relação ao primeiro.

LESCA \& ALMEIDA (1994) apud BRITO (1997), afirmam que as informações têm importância crescente para as empresas e para os países, porém as empresas brasileiras e francesas ainda possuem uma noção pouco desenvolvida sobre o uso da informação para fins estratégicos. Neste mesmo sentido, PALVIA \& PALVIA (1999) afirmam que, mesmo com a tendência de crescimento do uso da tecnologia da informação, este é principalmente para tarefas operacionais e administrativas, e não para propósitos estratégicos ou de tomada de decisão.

Porém, conscientes agora do valor da informação, as organizações têm problemas de acesso a estes dados operacionais, gerados pelos sistemas implementados nestes níveis. Eles foram desenvolvidos para atender somente às necessidades estáticas e operacionais dos funcionários destes níveis. Qualquer outro uso, que não este, apresenta problemas. Segundo 
DRUCKER (1996), até agora, a maior contribuição da nossa capacidade de processamento de dados não foi para o gerenciamento, mas sim para as operações.

\subsection{Enfoque tecnológico dos sistemas de informação}

Uma característica importante a ser observada é que os sistemas de informação foram desenvolvidos, ao longo do tempo, sempre com um enfoque extremamente técnico. As atenções sempre estiveram voltadas à tecnologia empregada e não ao uso estratégico dos sistemas de informação ou à adequação ao usuário. De acordo com McGEE \& PRUSAK (1994), o foco sempre esteve na tecnologia e nos enormes gastos com computadores e equipamentos e não nas reais necessidades informacionais. BIO (1996), compartilha desta afirmação, dizendo que as empresas sempre dedicaram excessiva orientação ao recursos técnicos, e houve falta de ênfase nos objetivos informacionais. O mesmo autor acrescenta que a maioria da literatura brasileira da área de tecnologia da informação parece concentrarse em questões técnicas de processamentos de dados. Ainda segundo o autor, os problemas dos sistemas de informações nas organizações não se resumem a questões técnicas de processamento de dados, mas à uma variada gama de questões conceituais, que não podem ser solucionadas com a mera utilização do computador, por mais evoluído que este seja tecnologicamente. McGEE \& PRUSAK (1994), acrescentam que é fácil acreditar que problemas e situações complexas, podem ser prontamente solucionadas com recursos financeiros e máquinas. Segundo os autores, o principal valor estaria na própria informação e não na tecnologia da informação; porém o alucinante ritmo de inovações tecnológicas atrai a atenção para a tecnologia. Os autores acrescentam que as necessidades de gerenciamento da informação devem acionar as alternativas tecnológicas e não o contrário. Os investimentos em tecnologia da informação não criam por si só vantagem como o uso de um novo maquinário. É o uso que damos à tecnologia da informação que cria valor, o uso da informação na organização. Os investimentos tecnológicos tornam-se nulos sem as informações adequadas e as pessoas usuárias.

Com o enfoque extremamente tecnológico e com os diversos problemas apresentados pela tecnologia da informação, WANG (1995), afirma que é tentador culpar o computador, mas o erro está na metodologia de desenvolvimento, e acrescenta que, insistir que a culpa é tecnológica, não resolve nada. Ainda segundo o autor, queixas dos executivos das organizações em relação ao pessoal de sistemas são constantes, e entre elas destaca-se a comunicação em termos técnicos e não em termos empresariais, e a perda de vista da atividade alvo da organização por influência de decisões tecnológicas. Ilustrando o enfoque tecnológico, em detrimento às reais necessidades informacionais das organizações, 
ABRAMSON (2000), cita a queixa de um executivo, de que todos da área de tecnologia da informação querem vender soluções, mas ninguém quer saber qual é o problema.

DRUCKER (1996), a respeito do enfoque tecnológico dado às aplicações de informática, afirma que para ser instruído em informações, o começo é aprender o que se necessita saber. $\mathrm{O}$ autor coloca que uma atenção demasiada é dada à tecnologia, e pior ainda, à velocidade do dispositivo - sempre mais e mais rápido, e que esta espécie de fixação tecnicista, faz perder de vista a natureza fundamental da informação na organização hoje. $O$ autor prossegue afirmando que, para organizar a maneira pela qual é feito o trabalho, é preciso começar com a tarefa específica, depois com as informações necessárias e finalmente os relacionamentos humanos indispensáveis à execução do trabalho. Ainda sobre o enfoque tecnológico, o autor coloca que a atual ênfase na reengenharia significa essencialmente mudar uma organização, do fluxo de coisas para o fluxo de informações. O computador é meramente uma ferramenta no processo. Agora que o conhecimento está tomando o lugar do capital, como força motriz nas organizações do mundo inteiro, é muito fácil confundir dados com conhecimento e tecnologia da informação com informação. $O$ pessoal dos computadores ainda está preocupado com maior velocidade e memórias de maior capacidade. Mas cada vez mais os desafios não serão técnicos; ao contrário, eles estarão ligados à conversão de dados em informações utilizáveis.

MARCHAND (1999b) afirma que mesmo a informática, facilitando a criação de redes, e o compartilhamento de informação entre administradores e empregados, o uso da informação deve ser analisado. O simples fato de colocarem estações de trabalho e outros recursos em redes para as pessoas da empresa, não aumenta automaticamente o uso inteligente da informação. $\mathrm{O}$ autor afirma que administradores enfrentam problemas ao alinhar a cultura e o comportamento da empresa, quanto à informação e às estratégias de negócio, que não se deve pensar que a informática irá resolver este problema, e à medida que a estrutura de informática fornece os instrumentos necessários à utilização da informação, a forma como as pessoas a utilizam é igualmente importante.

COSTA \& MIRANDA (1999) demonstram a importância de se focar não só a tecnologia no desenvolvimento de sistemas, ao afirmarem que o Software Engineering Institute (SEI), demonstrou, há muito tempo, que existe uma correlação maior entre o sucesso no desenvolvimento e o processo de desenvolvimento, do que com tecnologia ou outras ferramentas.

MELLO \& BURLTON (1999) abordam a gestão do conhecimento, na qual as empresas tentam gerenciar o conhecimento acumulado, visando maior competitividade. Segundo os autores, uma questão que sempre acaba vindo à tona é a do papel da tecnologia 
na gestão do conhecimento, e que a tecnologia pode, sem dúvida alguma, ajudar as pessoas a se comunicarem e se relacionarem, mas não gera conhecimento. Também não cria, no ambiente, todas as condições necessárias para o devido compartilhamento de conhecimento, se as pessoas não percebem suas vantagens ou mesmo a necessidade de colocá-lo em prática. Os autores afirmam que a tecnologia é um recurso necessário para a solução de problemas, mas é somente parte da resposta, e sugerem nunca começar pela tecnologia e não acreditar jamais que, simplesmente pelo fato de haver recursos disponíveis, as pessoas vão fazer o que se espera que elas façam.

Expondo a distância que existe entre a tecnologia e as reais necessidades de negócio, SILVA (1997) afirma que uma tarefa problemática na informática é analisar e definir o que um novo sistema deve apresentar para ser valioso aos seus usuários. Como fatores para esta problemática, o autor cita as dificuldades técnicas e políticas, os problemas de comunicação, o entendimento das necessidades dos usuários e o processo de desenvolvimento. Apesar da enorme quantidade de ferramentas e metodologias, cujo objetivo é melhorar a qualidade dos aplicativos, ainda persiste a questão de traduzir, adequadamente, para a linguagem da informática, os processos de negócio, suas restrições e regulações. Estes processos de negócio somente são conhecidos, e em grau variável, pelos próprios usuários. Os diagramas preconizados pelas metodologias têm se mostrado insuficientes para resolver a questão do entendimento e são, via de regra, de difícil compreensão pelos usuários e, mesmo quando eles participam da especificação de requisitos, o problema permanece. Neste mesmo sentido, BELLOQUIM (1999c) afirma que, devido aos altos índices de problemas com informática enfrentados pelas empresas, uma maior importância deveria ser dada a um aspecto muito negligenciado e difícil no desenvolvimento de software: a análise de requisitos. O problema é que obter os requisitos de um software é a tarefa menos estruturada, menos técnica e mais sujeita à influência das habilidades interpessoais de analista e usuário. O autor afirma que, neste ponto, o problema não são os diagramas para desenhar o que o usuário quer, mas sim, antes dos diagramas, descobrir o que o usuário quer. Assim, a questão não é apenas técnica, mas também multidisciplinar, exigindo a participação de profissionais de diversas áreas.

GONÇALVES J. L. M. (1999) afirma que novas tecnologias e técnicas de gestão surgem a todo momento, como ondas que varrem o mercado, que por trás destas ondas, existem os fornecedores e consultores, ávidos por criarem novos produtos. $\mathrm{O}$ autor explica como o mercado conseguiria criar novas demandas: quando o cenário está estabilizado, fornecedores e consultores possuem poucas chances de vendas; então partem para instabilizar o cenário, visando aumentar suas vendas. Estas ondas tornam-se mais freqüentes, 
e o que surpreende é a rapidez com que o mercado absorve as novas tecnologias, muitas vezes, com resultados insatisfatórios.

BELOQUIM (1999) condena os profissionais e instituições que orientam alunos ou demais profissionais quanto ao foco em modismos e tecnologias passageiras. $\mathrm{O}$ autor afirma que boa parte dos problemas que a informática apresenta hoje, é fruto de anos de desenvolvimento de software, por uma categoria profissional em que, infelizmente, o talento e o preparo nem sempre foram moeda corrente. O autor critica os cursos essencialmente técnicos, onde a carga de matemática e de disciplinas ligadas à máquina é muito forte, e onde o aluno sai achando que desenvolver software é apenas escrever código. O autor critica também os cursos que ensinam apenas as linguagens da moda, sem se preocuparem com conceitos e métodos que permanecerão quando estas linguagens desaparecerem. $\mathrm{O}$ autor afirma que cursos, que tentam diminuir a distância entre a formação dos profissionais e as necessidades do mercado, estão surgindo, mais ainda são muito tímidos, e muitas vezes são patrocinadas pelas próprias empresas que percebem esta necessidade. Nesta mesma linha, HUMPHREY (2001) afirma que os profissionais de software continuam sendo treinados como hackers, e GONÇALVES P. S. P. (1999) afirma que muitos cursos estão cheios de disciplinas essencialmente técnicas ou ultrapassadas, que ministram linguagens de programação, e não ensinam aos alunos o "como aprender".

SOARES (1995) aborda o culto à tecnologia, afirmando que a utilização de computadores tornou-se rotina, e o transformou em objeto de culto nas sociedades. Desta forma, os computadores, enquanto máquinas, são super valorizados, e o trabalho humano que ele exige, permanece oculto. Os efeitos miraculosos possibilitados pelos computadores necessitam de uma grande quantidade de trabalho humano, mas a idéia que se tem é de que os computadores parecem resolver todos os problemas da vida moderna. Sempre que se precisa atribuir racionalidade, competência e modernidade a uma tarefa, ela será dedicada a um computador, que se tornou o maior expoente do moderno nas sociedades, e o moderno é sempre visto como bom e racional, enquanto o tradicional é visto como arcaico e irracional.

HEHN (1999) afirma que as empresas enfrentam grandes problemas para descobrir que somente a tecnologia da informação não é suficiente, e que seus plenos benefícios só podem ser alcançados por meio das pessoas que dela se utilizam. Assim, o autor coloca que software e as pessoas devem estar alinhados, e que muitos processos de mudanças falham por não considerarem as pessoas. Atuando em apenas uma parte do processo, as demais partes resistem e rejeitam a mudança. O efeito é o da cadeira de balanço, que volta ao seu local original e nada muda. Nesta mesma linha, ABRAMSON (2000) afirma que é até fácil comprar tecnologia da informação, porém é muito difícil mudar a estrutura, a cultura, os 
processos e os hábitos relativos à informação em uma empresa, resultando em empresas ricas em tecnologia da informação, mas sem competência para lidar com as informações obtidas. As empresas que venceram a lutas são aquelas em que o agente de mudança foi incorporado nas implementações de sistemas. ABRAMSON (1999) em levantamentos realizados com especialistas em informática, apurou que é muito comum encontrar empresas que disponibilizam novas tecnologias aos funcionários, mas o treinamento adequado é pouco comum. Ainda nesta linha, as organizações percebem que o bom atendimento aos clientes é uma necessidade do atual ambiente de negócios, mas DAVIDOW (1999), afirma que, na busca pelo melhor atendimento aos clientes, a resposta não está nas tecnologias e nas coisas maravilhosas que elas nos permitem fazer, mas fazer a coisa certa para aumentar a produtividade de vendas. MUNRO et al. (1997) afirmam que estudos recentes mostram que uma proporção substancial do potencial retorno dos investimentos de informática em usuários finais, nunca são realizados. Um dos motivos é que muitas empresas acham simplesmente que a mera presença de ferramentas para os usuários finais irá aumentar a produtividade.

CALDAS \& WOOD (2000) realizaram uma pesquisa entre empresas que implantaram sistemas integrados de gestão, e destacam alguns achados importantes:

- $36 \%$ dos entrevistados afirmaram que a empresa não sabia direito o que estava comprando ou o que poderia esperar do sistema;

- para $41 \%$ dos entrevistados, a implantação foi imposta;

- para 30\%, dos entrevistados, o envolvimento do usuário foi baixo ou insuficiente;

- $24 \%$ dos entrevistados afirmaram que a implantação teve o foco nos aspectos humanos e suas transformações;

- $36 \%$ afirmaram que o processo teve seu foco orientado à tecnologia;

- $23 \%$ afirmaram que os consultores tinham a habilidade e a experiência necessárias;

- $45 \%$ responderam que não perceberam melhorias em vantagem competitiva;

- $43 \%$ não obtiveram redução do ciclo de tempo;

- $40 \%$ não obtiveram ganhos em serviço ao cliente.

Segundo os autores, as principais desvantagens citadas pelos entrevistados, nas questões abertas, entre outras, foram:

- o sistema falhou por não se adaptar às necessidades específicas do negócio;

- houve perda das funções organizacionais chaves, devido aos requerimentos do sistema; 
- houve redesenho superficial de processos.

Os autores afirmam que as implementações de sistemas integrados de gestão, envolvem grandes transformações nos processos organizacionais, com implicações significativas no modelo de gestão, na estrutura da organização, e particularmente, nas pessoas. Entretanto, mesmo com todos estes aspectos, os dados da pesquisa comprovam o direcionamento tecnológico das implementações e não uma abordagem integral da empresa. Os autores afirmam que muitas implementações falham por serem encaradas como mais um projeto da área de informática, e não como uma grande transformação organizacional, como deveria ser. Também evidenciando o isolamento de questões informacionais importantes da empresa, à área de informática, ALBRECHT (1999) afirma que um erro comum é achar que a qualidade da informação é um problema da área da informática, quando na verdade seria de todos os envolvidos.

FORESTI (2000) afirma que o fator técnico sempre teve peso dominante nas avaliações da área de tecnologia da informação, mas agora parece que este fator tem perdido um pouco sua força na definição final por determinado produto ou fornecedor. CIPULO(1999) escreve que colocar grandes volumes de recursos em sistemas de gestão empresarial, comprometendo, às vezes, até as finanças da empresa, sem ter caminhos estratégicos claramente definidos, resultam em nada para as mesmas.

Expondo o enfoque tecnológico da informática nas empresas, PARTNER (1999) cita uma pesquisa do Gartner Group, realizada com centenas de diretores de informática americanos e brasileiros. Os números mostram que, no Brasil, aqueles que decidem os rumos da tecnologia estão mais preocupados com a estrutura de hardware e software, do que em desenhar ou rever a forma como as empresas atuam junto aos seus clientes. Segundo o autor, não há visibilidade dos processos de negócio, e exemplifica a questão citando o data warehouse, uma ferramenta gerencial, mas que aparece como uma preocupação técnica e não estratégica para a maioria dos diretores de informática. STÁBILE \& CAZARINI (2000a) evidenciam o foco tecnológico como problemático nas organizações, escrevendo que um dos fatores críticos de sucesso do data warehouse é que ele deve ser guiado pelas necessidades do negócio, e não pela tecnologia empregada. ALBERTIN \& MOURA (1995) em um estudo entre instituições bancárias nacionais, sobre suas áreas de informática, relatam que os aspectos técnicos continuam tendo mais relevância que os gerenciais, e esta situação contribui para o relacionamento deficiente da área de informática com a organização. Os autores afirmam que os aspectos sociais e gerenciais começam a ser percebidos como críticos, mas ainda existe grande pressão para a utilização de novas tecnologias. 
NIMER (1997) aborda a administração de dados como problemática nas empresas e apresenta, como uma das causas, o fato desta função ser subordinada à área de informática, quando, na verdade, deveria ser à área de negócios. Segundo o autor, o perfil ideal do administrador de dados é o de um profissional que não precisa ter formação técnica muito profunda, mas sim, uma boa visão estratégica dos negócios e dos ramos de atividade da empresa.

BUCKHOUT et al. (1999) descrevem bem os problemas que surgem quando projetos são tocados sem objetivos estratégicos: os sistemas integrados de gestão aprisionam os princípios e processos operacionais da empresa, e depois da instalação, as modificações são quase inexistentes. O custo, complexidade, investimento em tempo e pessoal, as implicações e políticas de um sistema deste tipo são muito altos, requerendo uma implementação racional e econômica desde o início. Depois de terminado o projeto, as empresas concentram-se no software e não nos objetivos empresariais, com o pressuposto básico de que os benefícios virão. Assim, os diretores acabam transferindo muita responsabilidade aos técnicos, encarando o projeto como de tecnologia e não empresarial. A equipe técnica é quem toma as decisões cruciais, e não demora muito para que o projeto comece a apresentar problemas. Percebendo isto, a equipe técnica redesenha alguns processos empresariais e físicos, visando a rápida disponibilização para uso. É raro que isto funcione, pois sem objetivos empresariais, a empresa implementa um sistema mutilado ou carregado de funções desnecessárias. Neste mesmo sentido, GROVER et al. (1998) afirmam que investimentos em informática, sem mudanças nos processos organizacionais, podem afetar negativamente os efeitos da informatização, e que a mesma tecnologia pode apresentar resultados diferentes em empresas diferentes, dependendo da forma como ela é implementada.

MOREIRA (1998) afirma que nos processos de implantação dos sistemas integrados de gestão, muito dinheiro está sendo desperdiçado, não pelo software, pois a maioria é de qualidade, mas pelo processo de escolha. O processo de análise correto pode ser oneroso e demorado, assim, a maior parte do processo é consumida nos aspectos técnicos e financeiros, ficando para segundo plano, a análise de aderência ao negócio. O preço deste equívoco certamente será cobrado mais tarde. MAYER (2000a) afirma que muitos projetos de implantação de sistemas integrados de gestão falham pela ignorância do aspecto cultural da empresa usuária, em que características dos processos internos devem ser levantadas o quanto antes possível, pois se não for assim, haverá atrasos no cronograma e aumento nos custos. UM caminho sem volta (2000) cita uma pesquisa do Gartner Group, que aponta que 
$75 \%$ dos projetos de comércio eletrônico irão falhar. Dentre os principais erros, é citada a crença de que apenas a tecnologia é capaz de operar a mudança necessária.

\subsection{Diversidade de sistemas}

Grande parte das organizações não possuem planos de informatização integrados, ou seja, a informatização é incrementada conforme a demanda. Primeiro um departamento, depois outro, uma função específica, depois outra. Estas soluções isoladas, em princípio, são satisfatórias para os usuários. Porém, um grande problema surge após algum tempo. De acordo com TAURION (1998a), menos de 20\% das informações corporativas estão diretamente disponíveis aos usuários finais. Os $80 \%$ não estão diretamente disponíveis por dois motivos: conflitos de definição e diversidade tecnológica. Ao longo dos anos, vários sistemas de informação são desenvolvidos individualmente nas organizações e cada um deles possui seus próprios dados. Os sistemas não são integrados e formam verdadeiras ilhas de informação, sem ligações umas com as outras. Para o uso imediato, departamental e operacional, as soluções são até suficientes. Porém, as análises mais abrangentes e de mais alto nível, ficam impossibilitadas, pois os sistemas não se "conversam". As informações estão espalhadas pelos departamentos e encontram-se em várias versões. Algumas informações apresentam grande redundância por figurarem em vários locais.

WANG (1995) cita como problemas de tecnologia de informação nas organizações, a incompatibilidade entre sistemas, a pouca padronização, e o uso de plataformas diferentes. O autor acrescenta que a informatização departamental e operacional é satisfatória, porém a falta de comunicação com as demais áreas torna-se um problema.

LUZ (2000) expõe os problemas de integração dos sistemas nas empresas. Ele afirma que, para resolver antigos problemas de médias e grandes corporações, tais como, baixa integração entre sistemas, processos e dados, dificuldade no gerenciamento dos recursos destinados à informática, e insatisfação de usuários finais quanto às freqüentes demoras no atendimento das solicitações de melhorias nos aplicativos utilizados, os sistemas integrados de gestão, passaram a ser vistos como solução abrangente e definitiva. SCOTT \& KAINDL (2000) escrevem que, buscando integrar seus processos, as empresas investem em sistemas integrados de gestão, mas normalmente descobrem que algumas funcionalidades essenciais estão faltando. Entre os motivos das implementações destes sistemas, estão a frustração com sistemas legados incompatíveis e a incapacidade do pessoal de informática em integrar estes sistemas. Mesmo sendo sistemas grandes e complexos, que têm como objetivo integrar todos os processos organizacionais, muitos clientes descobrem que, no mínimo, $20 \%$ de suas necessidades funcionais estão fora do sistema. CALDAS \& WOOD 
(2000) realizaram uma pesquisa entre empresas que implantaram sistemas integrados de gestão. Levantaram que a principal razão para a implementação dos sistemas integrados de gestão é a integração dos processos e da informação. Percebe-se aqui, o quanto a falta de integração de sistemas e dados é problemática para as empresas.

BELLOQUIM (1999b) afirma que o grande fator de redução de produtividade em informática são os sistemas legados, quando estes carecem de qualidade. De acordo com o autor, dar manutenção em sistemas mal feitos e sem documentação é como "patinar numa poça de lama": gasta-se um monte de energia e não se chega a lugar nenhum. BELLOQUIM (1997) descreve a diversidade de sistemas nas empresas: durante a última década, as mais variadas novidades tecnológicas foram apresentadas como as soluções para todos os problemas; algumas, se bem implantadas, ajudaram as empresas, mas outras eram "abacaxis disfarçados", pois quase todas trouxeram problemas antes inexistentes; a maior falácia, por trás de toda esta propaganda milagrosa, é a suposição de que tudo que se tem hoje não existe mais, já que a impressão passada é que, todos os sistemas antigos serão convertidos e passarão, como em um passe de mágica, a desfrutar das características das coisas novas; um problema que poderá ocorrer nestas situações, é o surgimento de um ambiente multiplataforma de difícil administração, pois nenhuma empresa terá capacidade de migrar rapidamente todos os seus sistemas, mesmo que a nova tecnologia seja vantajosa; com a velocidade das mudanças da área, é comum vermos empresas alterarem seus planos de migração com os projetos já em andamento; nenhuma tecnologia poderá ser implantada rapidamente porque a maior dificuldade em desenvolver sistemas não é escrever código, mas entender o que o sistema deve fazer; assim, a grande maioria dos sistemas das empresas será composta por sistemas legados; outro agravante são os sistemas desenvolvidos pelos usuários; com alguns softwares mais amigáveis, o usuário percebeu que era mais rápido desenvolver suas próprias aplicações do que esperar pela área de sistemas; é praticamente impossível controlar estas aplicações, pois os usuários desenvolvem-nas mais e mais; este tipo de sistema pode apresentar algumas vantagens, como a rapidez de disponibilização, o conhecimento que só o usuário tem de seu trabalho e a melhor aceitação por ele mesmo e pelos seus pares; mas os problemas existem, pois sem conhecimento técnico, surgem programas mal projetados, sem segurança ou documentação; como estes sistemas tendem a ser amplamente utilizados, a empresa passa a depender deles, e quando o usuário sai da empresa ou é incluído na área de sistemas, a área herda o sistema; para completar a situação, os pacotes estão tornando-se mais freqüentes, porque as empresas perceberam que é mais barato comprar sistemas comuns; o problema é que as empresas compram pacotes que, absolutamente, não conversam com os anteriores, e, às vezes, até a plataforma necessária 
para rodar o novo aplicativo é incompatível com as anteriores; as últimas peças do quebra cabeça seriam os sistemas externos, desenvolvidos fora da empresa, às vezes impostos por clientes, fornecedores, ou o governo; o projeto destes sistemas não pode ser influenciado pela empresa, que é obrigada a utilizá-lo.

A figura 16 ilustra a descrição do autor:

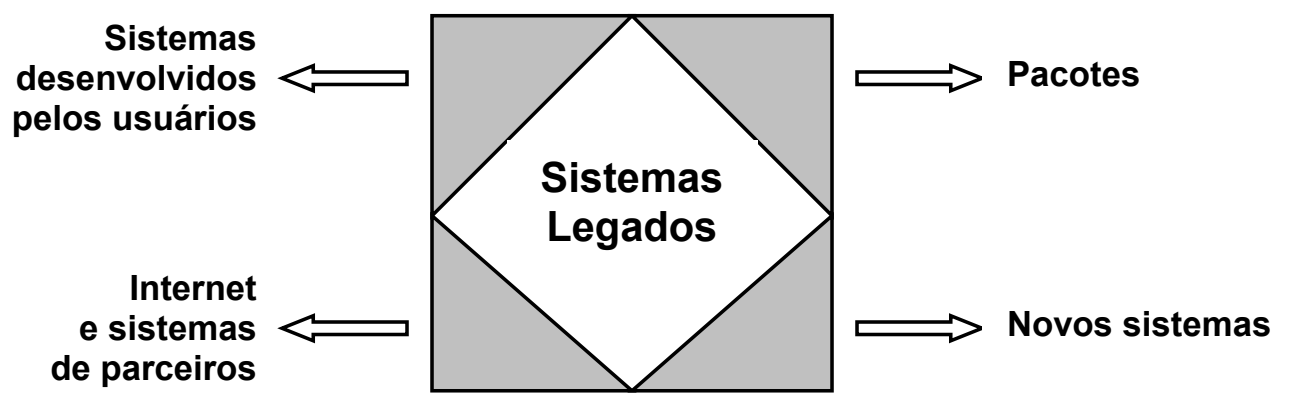

Figura 16 - Sistemas legados e as novas tecnologias - BELLOQUIM (1997)

Alguns dados ilustram o problema da diversidade tecnológica nas empresas: MAYER (2000b) apresenta uma pesquisa com aproximadamente 500 empresas usuárias de informática, relatadas no relatório Brasil InfoCorp, que mostra que o número médio de sistemas operacionais utilizados, cresceu de 3,92 em 1998 para 3,99 em 1999. MAYER (2000c) comprova a diversidade tecnológica, ao apresentar uma pesquisa realizada com 550 empresas usuárias, ou seja, empresas nas quais a atividade principal não é a informática, com o intuito de verificar as linguagens de programação utilizadas. Esta pesquisa demonstrou que linguagens tidas como mortas, tais como Clipper e Cobol, ainda têm presença marcante nas empresas. Outro dado, é que o número médio de linguagens de programação é de 1,8 por empresa. Porém esta média varia de 1,1 nas empresas com pequenas equipes de informática e chega a 2,6 em grandes equipes de informática.

INMON (1997) faz uma abordagem profunda do problema da diversidade de sistemas nas empresas. $\mathrm{O}$ autor afirma que a maioria possui a chamada arquitetura de desenvolvimento espontâneo, que ocorre quando uma organização adota a postura de deixar acontecer, em relação à arquitetura de hardware e software. Empresas com esta postura, terão problemas piores à medida que se tornam maiores ou mais maduras. Um outro nome citado pelo autor, para a arquitetura de desenvolvimento espontâneo, é teia de aranha, pois a empresa possui varias aplicações dispersas, e sobre estas diversas aplicações, são criadas extrações para acesso aos dados. Posteriormente, são criadas extrações das extrações, e em algumas empresas, o número de extrações é extraordinariamente grande. Com esta arquitetura, o autor afirma que, certamente, as empresas apresentam os seguintes problemas: 


\section{- falta de credibilidade dos dados;}

Departamentos distintos entregam um relatório à gerência com números absolutamente divergentes, e a conciliação entre os dois departamentos é quase impossível. Ao receber os relatórios, a gerência não sabe o que pensar e toma decisões baseadas em interesses políticos e opiniões pessoais. Esta situação exemplifica a crise de credibilidade dos dados. O autor cita quatro razões para esta crise:

- ausência de parâmetros dos dados: departamentos diferentes extraem os dados para análise em momentos diferentes;

- diferencial algorítmico: os departamentos podem utilizar formas de análise diferentes;

- níveis de extração: as extrações realizadas sobre os dados produzem outros dados diferentes, que podem sofrer outras extrações;

- geralmente não há uma fonte comum de dados, e os relatório são elaborados sobre dados diferentes.

- produtividade;

A gerência de uma empresa, que apresente a arquitetura de desenvolvimento espontâneo, precisa de um relatório corporativo utilizando as várias bases de dados que se acumularam durante anos. O pessoal destacado para a tarefa deve:

- localizar e analisar os dados para o relatório;

- compilar os dados para o relatório;

- obter recursos humanos de programação/análise para realizar os pontos citados acima.

Para a localização dos dados, muitos arquivos e layouts precisam ser analisados, e com agravantes: dois arquivos podem possuir campos de mesmo nome, mas com conteúdos diferentes; arquivos com nomes diferentes, em diferentes bancos de dados podem possuir o mesmo conteúdo. Este processo de levantamentos, não só de nomes, mas também de conteúdos, é muito maçante, porém deve ser feito, ou o relatório não será produzido. Sem a racionalização dos dados, a análise final será produzida sobre dados misturados, criando grande confusão. A próxima tarefa é a compilação dos dados levantados. Programas devem ser escritos para recuperar os dados das várias fontes identificadas. Este trabalho é problemático devido aos seguintes fatores:

- muitos programas devem ser escritos;

- cada programa deve ser customizado;

- os programas passam por todas as tecnologias de que a empresa dispõe. 
O processo de levantamento e elaboração de relatórios sobre bases de dados dispersas é longo, trabalhoso e oneroso. Se as próximas solicitações da gerência fossem conhecidas, os levantamentos realizados poderiam ser utilizados futuramente, diminuindo em muito o tempo e o custos de novos relatórios. Porém, como as novas solicitações não são conhecidas, e como quase sempre, elas não se repetem, os mesmos gastos são dispendidos a cada solicitação da gerência.

\section{- dos dados às informações}

Outra falha na arquitetura de desenvolvimento espontâneo é a impossibilidade de passar dos dados às informações, que parece simples, mas não é. Ao realizar os levantamentos nas bases de dados, afim de atender a uma solicitação de análise, o técnico irá descobrir uma das piores coisas a se fazer, uma vez que ele vai se deparar com a variedade de aplicações do ambiente herdado. Tentar descobrir como os dados se relacionam nos diferentes arquivos é uma tarefa difícil, e o uso de um critério geral para análise e extração é quase impossível. Critérios específicos para cada arquivo devem ser adotados, pois o desenvolvimento das aplicações nunca levou em conta a integração.

ANTUNES \& OLIVEIRA (1998) citam o caso de duplicação de registros nas bibliotecas da Embrapa, Empresa Brasileira de Pesquisa Agropecuária. Os autores afirmam que a duplicação de registros é resultado do cadastramento do mesmo material bibliográfico por bibliotecas diferentes. Na junção dos acervos locais, o mesmo documento pode aparecer várias vezes, de acordo com o número de bibliotecas que o registraram. Isto ocorre porque a inclusão de material bibliográfico é feita de forma descentralizada nas bibliotecas da Embrapa. Este exemplo pode ser perfeitamente estendido para empresas que possuem diversos sistemas não integrados, onde a entrada de dados é feita em sistemas distintos que não se comunicam, levando à duplicação de dados. Esta duplicação, por si mesma, causa problemas de armazenamento e gerenciamento, e, quando são necessários levantamentos, a duplicação prejudica intensamente a velocidade e credibilidade.

CALDAS \& WOOD (2000) denominam como um problema crônico, a fragmentação dos dados nas empresas, onde cada área investe muito dinheiro em seus próprios sistemas de informação, que não se comunicam uns com os outros e causam uma grande falta de informação para a tomada de decisão. WELLS et al. (1999) também citam como problema organizacional, a situação de fragmentação dos dados organizacionais em sistemas e áreas diferentes da empresa, onde um mesmo cliente pode, por exemplo, apresentar vários números de identificação. Esta visão fragmentada dos clientes dificulta a utilização coerente dos dados. A integração dos mesmos, pela migração dos sistemas 
legados, é um trabalho tedioso e complexo, mesmo com novas ferramentas que surgem para esta tarefa

SHANKS \& DARKE (1999) escrevem que profissionais de informática e usuários sentem dificuldade ao tentar entender os modelos de dados corporativos. Segundo os autores, freqüentemente os dados estão duplicados nas empresas, resultando em dados inconsistentes, armazenados em diferentes formatos que apresentam dificuldade de consolidação. $\mathrm{O}$ uso de modelos de dados corporativos é problemático na prática. Estudos reportam que eles são muito complexos, volumosos e inflexíveis, sujeitos à problemas políticos e organizacionais e considerados irrelevantes para o planejamento estratégico por executivos chefes. Segundo os autores, estes modelos são necessários nos projetos de sistemas inter-funcionais, que integram diversas fontes de dados. Porém, eles são de difícil entendimento, tanto para profissionais de informática como para usuários, tornando-se barreiras ao seu uso, e isto é comprovado por vários estudos. O modelo é muito abstrato e os termos usados não são familiares às áreas de negócio. Sem esta comunicação, seu desenvolvimento e uso são prejudicados. Vários estudos mostram que o modelo Entidade-Relacionamento é difícil de ensinar, e na prática, apresenta dificuldades de entendimento, afastando os usuários.

JUNTOS outra vez (1999), apresenta a citação de Cairo Ferreira, gerente de canais da Network Appliance, produtora de sistemas de armazenamento de dados, onde ele afirma que as redes das empresas cresceram de forma não muito ordenada e planejada. Primeiro as empresas utilizaram os mainframes, depois, as redes de micros, o que fez com que hoje as bases de dados estejam pulverizadas em vários servidores e plataformas, dificultando o gerenciamento e comprometendo a integridade e o controle desses dados. Na mesma reportagem, Fábio Kimura, gerente de storage da HP para a América Latina, afirma que a maior parte das empresas do Brasil, continua com sua estrutura de armazenamento de dados descentralizada, o que dificulta a administração e aumenta os custos. CHEN et al. (2000) afirmam que, nos últimos anos, as empresas armazenaram grandes quantidades de dados, e este volume continua a crescer rapidamente. Ao mesmo tempo, as ferramentas para os usuários finais resultaram em um grande número de bancos de dados nas empresas, freqüentemente armazenados em formatos incompatíveis. Como resultado, surge a necessidade de controlar o armazenamento, o acesso e o processamento dos dados dispersos, e esta irá influenciar no uso eficiente dos dados.

FLORENZANO (2000a) afirma que os executivos de tecnologia da informação estão encontrando grandes dificuldades ao tentarem tornar acessíveis pela Internet, os dados que possuem armazenados há décadas em suas empresas. Segundo a autora, a soma das informações geradas pelos sistemas de retaguarda, com os novos dados que chegam a cada 
segundo pela Internet, normalmente, resultam em grande confusão, já que esta não é uma equação simples ou fácil de resolver, pois envolve desde grandes investimentos a questões de cultura da empresa. Também sobre comércio eletrônico, GARVEY (1999) cita o depoimento de Carl Greiner, vice presidente e analista do Meta Group, afirmando que a maioria das companhias descobrirá que é mais estratégico do que nunca manter seus sistemas legados, pois quem quiser atuar no mundo do comércio eletrônico deve alavancar os sistemas legados, já que não se pode substituí-los com a rapidez necessária, e ainda estar pronto para as necessidades comerciais. O analista afirma que $70 \%$ dos dados do mundo estão em sistemas legados. INTEGRAÇÃO é fundamental (1999) afirma que uma das principais preocupações dos diretores de informática, que estão implantando sistemas que utilizem a Internet, é a integração destes novos serviços com os sistemas tradicionais da empresa. Criar um ambiente paralelo, além de improdutivo, pode resultar em problemas extras na hora de consolidar os dados.

OS prazeres e as dores da integração (2001), afirma que as empresas estão adotando diferentes estratégias para integrar suas vendas online com os sistemas tradicionais. A única unanimidade entre elas é que o processo é necessário e complexo. Como benefícios de um sistema único, tem-se o melhor serviço de atendimento ao cliente e a consistência nos processos comerciais. Um estudo mostra que $76 \%$ das lojas online não conseguem unificar dados dos clientes dos diversos canais de vendas, e afirma que, se a empresa não servir seus clientes de forma integral em todos os canais, estará oferecendo a eles, uma experiência em pedaços. A reportagem coloca que, geralmente, as empresas administram algumas operações centrais em sistemas de computadores mais velhos, e as aplicações online estão sendo desenvolvidas com tecnologias mais novas. Apesar de alguns softwares ajudarem no processo de integração, o esforço ainda envolve uma programação consumidora de tempo e de trabalho na conversão dos dados.

SUBRAMANIAN et al. (1997) pesquisaram os esforços de integração dos dados da prefeitura da cidade americana de St. Louis, que se encontravam espalhados por diferentes plataformas e bancos de dados. Como problemas, os autores levantaram:

- a conversão dos sistemas legados, alguns com décadas de uso;

- o tempo de resposta dos sistemas em picos de uso;

- o compartilhamento de informações entre departamentos era impossível por estarem em sistemas diferentes;

- os sistemas foram desenvolvidos com estratégias particulares e não única para toda a prefeitura;

- o gerenciamento dos dados era extremamente difuso e disperso. 
BRITO (1997) estudou a influência da informática na estratégia da Cooperativa Regional de Cafeicultores, em Guaxupé - MG, responsável pela comercialização de uma significativa parcela do café brasileiro. Em seu estudo, o autor levantou os seguintes problemas:

- lenta troca de dados entre os núcleos e a sede;

- duplicidade de trabalho;

- vários softwares sem conectividade;

Na reformulação da informática pela empresa, o principal obstáculo encontrado pelo autor foi a difícil conectividade dos softwares existentes. Este mesmo problema é evidenciado por SONDA et al. (2000), que pesquisaram as principais falhas presentes nos software de custos existentes no mercado, e entre elas estava o problema de interface com outros sistemas.

ERP: mantenha-o simples (1999), cita o caso de um banco norte americano, onde um novo sistema de gestão de recursos humanos seria instalado com o prazo previsto de doze a dezoito meses. Na verdade, a implantação levou quatro anos, porque cada um, dos muitos departamentos do banco, insistiu em acrescentar seus próprios recursos customizados e vários replicavam características do sistema de recursos humanos legado, que estava sendo substituído. Em um outro exemplo, PARA além da confusão (2000), cita o caso da Companhia de Processamento de Dados do Município de São Paulo, (Prodam), que vai permitir através de um site, que os cidadãos acessem diversas informações. Desde o início do projeto, de acordo com um dos diretores da companhia, Waldemar Bonjr, o maior desafio tem sido integrar as centenas de aplicativos que estão em diversos bancos de dados diferentes.

UMA nova abordagem para integração (2000) aborda a integração de aplicativos, como sendo rara e luxuosa, para poucas empresas que a conseguiam de forma coerente. Porém, hoje esta integração é imperativa e fundamental para o sucesso das empresas no novo ambiente competitivo. A abordagem de integração, que no passado se referia apenas ao intercâmbio de dados, agora tem o enfoque de processo, ou seja, a empresa precisa controlar seu processo corporativo como um todo. A reportagem cita um estudo da Strategic Focus, uma empresa de pesquisa de mercado, concluindo que, apenas $28 \%$ dos entrevistados são capazes de integrar seus dados e aplicativos, $15 \%$ dos entrevistados não são capazes de integrar nenhum dos dois.

ANGUS (2000) afirma que as empresas continuam encontrando dificuldades de integrar seus aplicativos internos, pois o formato dos dados e as estruturas das mensagens podem variar radicalmente entre sistemas de fornecedores diferentes e até mesmo entre 
sistemas dos mesmos fornecedores. Assim, torna-se praticamente impossível o compartilhamento dos dados ou o fluxo de trabalho estruturado. A estruturação e o gerenciamento da cadeia de suprimentos e de outros processos colaborativos enfrentam os mesmos desanimadores problemas de comunicação. Ainda que fornecedores e compradores utilizem os mesmos distribuidores de softwares corporativos, a estruturação dos dados e outras personalizações provavelmente são diferentes e, com o tempo, essas divergências se acentuam. FLORENZANO (2000c) afirma que muito se tem falado sobre a integração de sistemas nas empresas, e que recursos para este problema não param de surgir. Neste contexto, a autora afirma que se pode pensar que as empresas estão navegando em um mar de soluções, mas a realidade mostra que os problemas desta área ainda ultrapassam as soluções.

LEITE (1994) afirma que por mais compatíveis que sejam dois aplicativos, sempre haverá algumas condições especiais e particulares em que os dois sistemas não trocarão dados com a suavidade desejada. Também não são raros os casos em que o hardware locado junto ao prestador de serviço se mostra incompatível com o software contratado de outro. A autora afirma que o trabalho de meio de campo com interfaces é delicado e complicado. Quando o assunto é a troca de dados entre sistemas aplicativos, o ideal é que a própria empresa contratante se encarregue deste serviço. Freqüentemente, prestadores de serviços não gostam da idéia de colocar remendos em seus sistemas, achando sempre que a responsabilidade é de outro, e a empresa contratante enfrenta um jogo que pode ser muito prejudicial. A autora afirma, ainda, que se as atividades são centralizadas em único parceiro, provavelmente, ganham-se vantagens na integração dos diversos serviços, mas ao mesmo tempo, cria-se uma maior dependência a um único fornecedor. Se por outro lado, as atividades são escolhidas entre fornecedores diferentes, a empresa pode criar uma excessiva diversidade, com dificuldades no gerenciamento técnico e também administrativo.

O problema de diversidade e falta de integração dos dados nas empresas, não é apenas tecnológico, mas também político. KOH \& WATSON (1998) afirmam que as pessoas e grupos, nas empresas, sentem-se donos de seus dados e percebem estes como fonte de poder, resultando em vários problemas. Os autores colocam que existem situações nas empresas, em que os mesmos termos possuem diferentes significados em áreas distintas. Quando a empresa deseja criar uma política de informação integrada e global para seus decisores, estes termos devem ser definidos para toda a organização. A integridade dos dados é um fator crucial nos sistemas utilizados pelos decisores organizacionais. A menor falha na acuracidade dos dados leva à perda da credibilidade destes sistemas por parte dos executivos. SCOTT \& KAINDL (2000) escrevem que a integração das informações dos vários 
departamentos, nos sistemas integrados de gestão é muito difícil, pois os departamentos não se comunicam e existe a sensação de que as informações são propriedades exclusivas dos departamentos que as criaram, e que ninguém de fora deve ter acesso à elas.

\subsection{Considerações finais do Capítulo 4}

Neste capítulo, foram abordados os benefícios esperados pelas organizações ao investirem em tecnologia da informação. Em seguida, foi mostrado que nem sempre estes investimentos produzem os retornos esperados, e que reclamações dos administradores são constantes. Como problema da tecnologia da informação nas organizações, foi apresentada a desconexão entre usuários e desenvolvedores de sistemas de informação, e que esta desconexão entre as partes, tende a criar nas empresas, enfoque operacional e tecnológico dos sistemas de informação, além da diversidade de sistemas. 


\section{Capítulo 5 - Como a desconexão afeta a obtenção de informação pelo decisor}

\subsection{Considerações iniciais}

Neste capítulo, é apresentado como a desconexão entre usuários e desenvolvedores de sistemas de informação, interfere na obtenção de informação pelo decisor organizacional. Mais especificadamente, é abordada a interferência dos três aspectos apresentados no capítulo 4: o enfoque operacional, o enfoque tecnológico e a diversidade de sistemas

\subsection{Enfoque operacional dos sistemas de informação}

Os sistemas de informação tradicionais informatizam satisfatoriamente o nível operacional das organizações, mas deixam a desejar quando se referem às necessidades do alto escalão. CASSARRO (1994) e BIO (1996), diferenciam informação operativa de informação administrativa. A informação operativa é aquela necessária à realização de uma operação ou de um processo específico, dentro do ciclo operacional da organização, como por exemplo, uma requisição de retirada de material do almoxarifado ou uma nota fiscal. Já a informação administrativa, é todo o resumo de informações operativas que chega até um administrador, pondo-o a par de sua competência, de sua responsabilidade, permitindo-lhe tomar uma decisão, como por exemplo, resumos de vendas por região.

As atividades dos administradores das organizações resumem-se basicamente à tomada de decisões, e, destas decisões, depende a sobrevivência da organização. Para a correta tomada de decisão, estes profissionais necessitam possuir informações específicas e precisas para a situação, e estas informações devem ser obtidas de forma rápida e flexível. Segundo STEWART (1998), a excelência é fruto das escolhas mais inteligentes. Assim, para que os administradores e executivos possam escolher bem, é essencial que tenham disponíveis, no momento e na forma exata, todas as informações de que precisam. De acordo com BIO (1996), os profissionais dos diferentes níveis têm necessidades de informações absolutamente diferentes. Como os sistemas de informação tradicionais estão focados no nível operacional, tem-se a carência por ferramentas eficientes de informações do alto escalão.

BEUREN (1998), afirma que quanto maior for a sintonia entre as informações fornecidas e as necessidades informativas dos gestores, melhores decisões poderão ser tomadas. Os sistemas de informação tradicionais, operativos, não possuem esta sintonia com as necessidades informacionais dos gestores, ou seja, falta alinhamento estratégico. Os relatórios e consultas, proporcionados pelos sistemas de informação tradicionais, são 
projetados para atender a problemas mais estruturados no nível operacional. Os usuários deste nível têm necessidades mais estáticas, portanto, para o desenvolvimento do sistema de informações, consultas e relatórios específicos para essas necessidades são projetados e implementados. Porém, as necessidades informacionais dos executivos e administradores são bem diferentes. Estes lidam basicamente com problemas não estruturados, e cada situação, geralmente, requer informações e apresentações destas de formas diferentes, o que não é proporcionado pelos sistemas de informação tradicionais. Quando novas consultas e relatórios são solicitados às equipes de sistemas, estes podem demorar dias ou meses para ficarem prontos, prejudicando em muito o desempenho dos administradores e executivos.

As consultas e análises necessárias aos administradores e executivos, além de geralmente serem referentes a problemas não estruturados, tornam-se cada vez mais complexas e críticas, devido ao crescente aumento da competitividade e flexibilidade do mercado. Os relatórios e consultas inflexíveis dos sistemas de informação tradicionais, dificilmente aplicam-se de forma satisfatória à estas consultas e análises

SAVIANI (1998), explica que os sistemas de informações sempre foram problemáticos para as empresas. $\mathrm{O}$ autor salienta, entre outros motivos, que estes sistemas sempre foram dirigidos a níveis inadequados na estrutura organizacional, e que seus projetos sempre foram considerados isoladamente. WANG (1995), compartilha desta afirmação, complementando que as informatizações departamentais operacionais são satisfatórias, porém sem comunicação com as demais áreas. OLIVEIRA (1996), considera três níveis de abordagens na abrangência de um sistema de informação administrativo: estratégico, tático e operacional; cada um dos níveis tem influência no sistema quanto ao foco de análise.

BIO (1996) explica que uma das grandes frustrações dos executivos das empresas, reside no fato de não poderem utilizar, em suas decisões de nível tático e estratégico, informações já coletadas pelas aplicações de nível operacional. Tal fato ocorre basicamente, por que dificilmente essas necessidades de informações podem ser planejadas e os recursos disponíveis fazem com que, quando as solicitações surjam, haja sempre uma demora para que o pessoal de sistemas responda através da geração de novos relatórios ou alterações dos já existentes. Normalmente, essas necessidades de informação são altamente perecíveis: bastam alguns dias ou mesmo algumas horas para que caso não tenham sido atendidas, sejam abandonadas. McGEE \& PRUSAK (1994) acrescentam que os executivos lidam com problemas menos estruturados do que os de níveis operacionais, sendo assim, não são atendidos pelos sistemas de informação desenvolvidos para estes níveis. MONTANA \& CHARNOV (1998), afirmam que gerentes diferentes têm diferentes necessidades de informações. O nível mais alto da administração, responsável pela direção da empresa, 
necessita de informações de natureza ampla e estratégica. Já, um gerente operacional, requer informações detalhadas sobre o dia-a-dia das operações, ou seja, informações diferentes daquelas dos gerentes da cúpula.

O fato das organizações estarem conscientes de que a informação é essencial, e que ela está em toda a parte da organização, já representa um grande avanço. Porém, tornam-se necessárias agora, ferramentas de tecnologia da informação específicas para agrupar esta diversidade de informações e permitir sua análise e uso estratégico pelos níveis administrativos e executivos das organizações, características não suportadas pelos sistemas tradicionais. Sendo o trabalho administrativo caracterizado por incertezas, atividades descontínuas e respostas a estímulos que variam no tempo, um sistema de informação desenvolvido para atender necessidades informacionais mais estáticas dos níveis operacionais, não tem a capacidade de atender às necessidades informacionais dos administradores, mesmo porque, o ambiente organizacional apresenta-se turbulento e imprevisível, com mudanças constantes e um maior número de variáveis, tornando os problemas mais complexos. WELCH (2000) coloca que, hoje, as mudanças medem-se em dias, e que velocidade é poder. Logo, a capacidade e velocidade de respostas às muitas variáveis que influenciam o ambiente organizacional, representam um fator muito importante na condução dos negócios. O administrador necessita de todas informações no momento e formatos desejados, para reagir satisfatoriamente às situações que aumentam em complexidade e freqüência. Os sistemas de informacionais operacionais não conseguem fornecer estas informações. Segundo DRUCKER (1996), uma base de dados, por maior que seja, não é informação. Ela é minério de informação. Para que a matéria prima se transforme, ela precisa ser organizada para uma tarefa, dirigida para um desempenho específico, aplicada a uma decisão. Ela não pode fazer isto por si mesma, nem os especialistas em informação.

PINHEIRO (1999), coloca que os sistemas de bancos de dados e suas aplicações otimizam e controlam os processos organizacionais com o foco voltado para as transações em si. Este tipo de ambiente é ideal para o controle operacional da organização, porém os decisores não são atendidos por estes tipos de sistemas. A maioria das organizações possui uma grande quantidade de dados, muitas vezes armazenados em locais diferentes e por diferentes bancos que, normalmente, não se comunicam, dificultando o uso da informação. A forma como estão armazenadas estas informações impede sua análise adequada para a tomada de decisões. Os usuários envolvidos nos processos decisórios gostariam de ter respondidas, de forma rápida e precisa, questões referentes ao seu segmento de negócio. As aplicações operacionais até conseguem responder, mas de forma inadequada quanto à velocidade e à precisão dos dados. 
VECCHIA (1998) afirma que, durante décadas, os dados históricos foram totalmente ignorados pelas empresas, mas hoje assumem um papel fundamental para a tomada de decisões de alto nível. Esses dados brutos, transformados em informação, segundo visões de negócio, são disponibilizados fornecendo uma rica base de informações utilizada para a tomada de decisões. NIMER \& SPANDRI (1998) colocam que o imenso volume de dados operacionais das empresas, se bem gerenciados, podem proporcionar vantagem competitiva. Pela grande quantidade de dados e pela impossibilidade de gerenciamento em tempo hábil pelos sistemas tradicionais, as empresas estão implantando novas ferramentas, como foco mais gerencial do que operacional.

DECISÃO inteligente (1999), a respeito do enfoque operacional dos sistemas de informação, cita o caso de uma empresa produtora de isopores, a Termotécnica, onde os executivos demoravam um dia inteiro para desenvolver relatórios, pois as aplicações possuíam enfoques operacionais, e não gerenciais. Outro caso semelhante, citado por $\mathrm{O}$ LIMITE é a criatividade (2000), é uma indústria com mais de 1200 ítens em sua linha de produtos, a Pincéis Tigre, onde a elaboração de relatórios para os gerentes consumia mais de três dias, também devido ao enfoque operacional dos sistemas utilizados.

PENTEADO (1999c) afirma que mesmo as organizações que investiram em sistemas integrados de gestão, ainda não obtiveram as grandes melhorias que almejavam, pois estes possuem enfoque operacional. Mesmo estas empresas necessitam de ferramentas que acrescentem inteligência ao conglomerado de informações geradas e armazenadas por estes sistemas. A autora cita uma empresa fabricantes de motores, a Cummins, que segundo o gerente de tecnologia, Lúcio Nubile, apesar de implantar um software de gestão empresarial para controle dos processos, afirma que este software não oferece quase nenhuma informação gerencial. LACHTERMACHER (1999) exemplifica a distinção entre aplicações operacionais e gerenciais, citando a Santista Alimentos, onde cada gerente trabalhava com a base de dados de seu departamento, e a empresa usava informações desencontradas sobre o mesmo assunto. A empresa implementou um sistema integrado de gestão para resolver a questão da integração, mas desde o início, sabia que este tipo de sistema iria focar o nível operacional, e não serviria para gerar informações gerenciais. Porém, a autora afirma que muitas empresas erram ao não fazer esta distinção.

INMON (1997) afirma que nas empresas, geralmente, as aplicações contém dados apenas para satisfazer as consultas atuais e específicas de cada aplicação, e não análises históricas ou mais abrangentes. Nestes casos, as aplicações são inadequadas à tarefa de apoio às informações, devido a sua falta de integração e à sua diferença entre o horizonte de tempo 
necessário ao processamento analítico e o horizonte de tempo disponível nas aplicações operacionais. $\mathrm{O}$ autor diferencia dados operacionais e analíticos, de acordo com a tabela 16 :

Tabela 16 - Dados operacionais e dados analíticos - INMON (1997)

\begin{tabular}{|c|c|}
\hline Dados operacionais & Dados analíticos \\
\hline Baseados em aplicações & Baseados em assuntos ou negócios \\
\hline Detalhados & Resumidos ou refinados \\
\hline Atendem à comunidade funcional & Atendem à comunidade gerencial \\
\hline $\begin{array}{l}\text { Requisitos de processamento são } \\
\text { conhecimentos com antecedência }\end{array}$ & $\begin{array}{l}\text { Requisitos de processamento não são } \\
\text { conhecidos com antecedência }\end{array}$ \\
\hline Voltados para transações & Voltados para análise \\
\hline $\begin{array}{l}\text { Pequena quantidade de dados usada em um } \\
\text { processo }\end{array}$ & $\begin{array}{l}\text { Grande quantidade de dados usada em um } \\
\text { processo }\end{array}$ \\
\hline Atendem às necessidades cotidianas & Atendem às necessidades gerenciais \\
\hline
\end{tabular}

O autor afirma que há uma grande quantidade de diferenças entre os dois tipos de dados, e afirma ser espantoso que os técnicos tenham pensado que os dois tipos pudessem encaixar-se em um único banco de dados.

A qualidade da informação só pode ser julgada pelo usuário. Uma informação só é útil, quando atende às necessidades do usuário em seu contexto decisório. Se um sistema de informação, por melhor que seja tecnicamente concebido, não consegue oferecer as informações desejadas pelos usuários, no momento e formato desejados, este sistema não oferece informações de qualidade. Neste mesmo raciocínio, o excesso de informação tornase tão prejudicial quanto a falta de informação. As informações específicas para uma decisão são únicas. Todas as informações disponibilizadas, que não são solicitadas pelo decisor, constituem lixo, e só atrapalham o processo decisorial. O administrador decisor, ao utilizar sistemas de informações tradicionais, focados na precisão dos processos operacionais, encontra problemas ao tentar obter somente as informações realmente úteis à uma decisão.

A figura 17 ilustra o foco operacional da maioria dos sistemas de informação, e a atuação dos administradores nos níveis superiores:

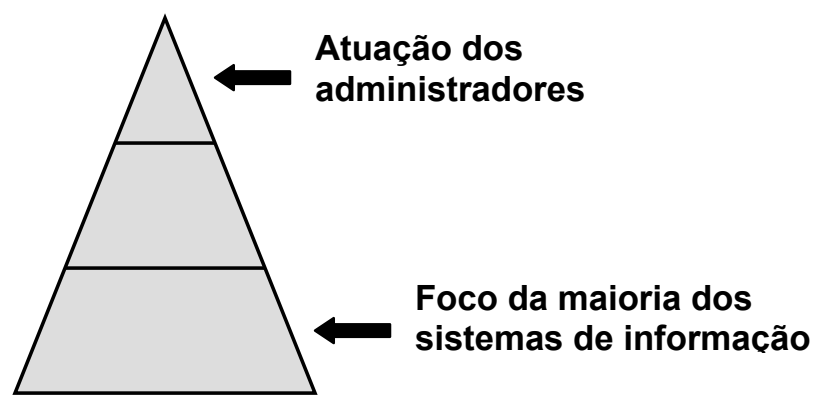

Figura 17 - Foco operacional dos sistemas e a atuação estratégica do administrador 


\subsection{Enfoque tecnológico dos sistemas de informação}

$\mathrm{O}$ enfoque tecnológico dado à informática prejudica muito o trabalho do administrador. A velocidade de evolução desta tecnologia é surpreendente, e muitas vezes, infelizmente, atrai os holofotes, quando estes deveriam estar no fornecimento de informações de qualidade e não na tecnologia em si. Em grande parte das organizações, segundo a bibliografia revisada, a tecnologia da informação é tomada como o fim em si, quando esta deveria ser apenas o meio para o fornecimento de informações de qualidade.

MACEDO (1999) afirma que uma ferramenta específica, por mais atualizada tecnologicamente que esteja, não é suficiente para resolver e endereçar todas as questões relacionadas ao processamento das informações nas organizações. Somente quando são utilizadas tecnologias apropriadas, em conjunto com práticas efetivas (novas ou existentes), os indivíduos da organização podem tirar proveito de seus conhecimentos. SANCHES (2000) afirma que são inúmeros os casos em que a total inadequação da tecnologia aos processos, impacta pesadamente nos negócios das empresas.

ERP - Mantenha-o simples (1999) afirma que os sistemas integrados de gestão empresarial foram tomados como a solução para integrar os processos de negócio das organizações, antes espalhados pelos vários departamentos e vários sistemas legados. Quando este tipo de sistema é implementado de forma rápida, ou seja, sem adequação aos processos e às pessoas, a organização perde em funcionalidade. Segundo o Gartner Group, nestes casos, os usuários atingem apenas $50 \%$ a $60 \%$ das metas que buscavam, pois podem estar sacrificando processos comerciais únicos, que dão às empresas, vantagem competitiva. HEHN (1999) afirma que o hardware e o software evoluiram muito, tornando-se mais e mais poderosos, mas o peopleware - pessoas - tornou-se o ponto fraco do sistema, e as empresas estão percebendo que somente a tecnologia da informação não basta.

Desde o início da concepção de um sistema de informação, se este não assumir os requisitos dos usuários, dificilmente, quando de sua colocação em uso, irá produzir as informações de qualidade desejadas. De acordo com JURAN \& GRYNA (1991), produto é o resultado de um processo. Um sistema de informação pode ser encarado como um processo, e seu produto, a informação. Tomando o usuário do sistema de informação como cliente, que possui necessidades a serem atendidas, como um processo orientado para a tecnologia conseguirá oferecer produtos que vão de encontro às necessidades dos clientes?

Como agravante ao enfoque tecnológico, em detrimento ao enfoque estratégico, a não integração do pessoal de tecnologia da informação com seus clientes usuários, aumenta a lacuna da desconexão entre as necessidades informacionais e as informações oferecidas. Segundo os conceitos de qualidade, ao se desenvolver um novo produto, é realizada uma 
pesquisa de mercado para descobrir o que o cliente quer. Sabendo das necessidades dos clientes, todo um projeto é implementado para criar um produto que atenda à estas necessidades e faça com que o cliente fique satisfeito.

$\mathrm{Na}$ tecnologia da informação, infelizmente, em muitos casos, existe pouca ou nenhuma integração. A área de tecnologia da informação, quando trabalha isolada, seu foco está na tecnologia em si, e sua comunicação é precária, tornando-se incapaz de obter dos usuários clientes, suas necessidades informacionais. Neste contexto, é praticamente impossível desenvolver sistemas de informação que realmente atendam aos usuários. Como oferecer uma informação de qualidade sem saber o que o usuário quer? O fluxo está invertido. Segundo os conceitos de qualidade da informação, que dizem que esta só existe se atender às necessidades do usuário, as informações disponibilizadas por estes sistemas são de má qualidade, pois não satisfazem a ele.

Porém, existem administradores que também são culpados, no todo ou em parte, por esta situação, por não assumirem a importância da área de tecnologia da informação na organização e também por não partilharem seus objetivos estratégicos. Neste ambiente sem integração entre produtor e cliente, é muito difícil oferecer informações de qualidade. Sem informações de qualidade, o trabalho do administrador é bastante prejudicado.

\subsection{Diversidade de sistemas}

As informações espalhadas por vários sistemas sem integração, constituem um grave problemas aos decisores organizacionais. De acordo com TAURION (1998a), menos de $20 \%$ das informações corporativas estão diretamente disponíveis aos usuários finais. Os $80 \%$ não estão diretamente disponíveis por dois motivos: conflitos de definição e diversidade tecnológica. As informações estão armazenadas como verdadeiras ilhas sem ligação. Assim, o desempenho dos profissionais do alto escalão é grandemente prejudicado. Informações extremamente importantes são conseguidas após muito esforço e levantamentos demorados. Mesmo assim, nem sempre os dados são confiáveis. STEWART (1998), exemplifica bem esta situação, citando que a incapacidade na troca de informações entre sistemas de computadores incompatíveis é um grande problema. Ninguém sabe, por exemplo, o volume de negócios efetuado com o maior fabricante de computadores do mundo, pois cada departamento armazena isoladamente suas informações a respeito do assunto e os sistemas não são integrados. Mesmo após gastar muito dinheiro para integrar os sistemas, ainda não se consegue levantamentos completos, pois em um departamento consta IBM, em outro I.B.M. e ainda em outro, International Business Machine. 
Um fato observado com freqüência é o envio, pelos diversos departamentos da organização, de relatórios para os executivos. De acordo com ACKOFF (1988), cada departamento se acha mais importante do que os outros e, literalmente, bombardeia os executivos com uma infinidade de relatórios, que somente atrapalha seu trabalho. Estes relatórios são úteis para o nível operacional; já os executivos têm necessidades de informações específicas para seu trabalho. Muitas vezes necessitam ficar "navegando" pelos vários relatórios que recebem e realizar levantamentos manuais e demorados para conseguir uma informação importante. Segundo o autor, sob a ótica do executivo, estes sistemas podem ser chamados de verdadeiros "sistemas de desinformação". Ainda de acordo com o mesmo autor, pesquisas mostram que $2 / 3$ das informações, que chegam aos executivos, não foram solicitadas por eles, e mesmo se passassem todo o expediente lendo a íntegra do material que recebem, não conseguiriam assimilar tudo. Isto prova que, quanto maior o excesso de informação ruim ou não solicitada, menor é o aproveitamento.

McGEE \& PRUSAK (1994) citam um caso, onde um executivo novo em uma empresa, solicitou uma cópia de cada relatório utilizado pela organização. No dia seguinte, recebeu 23 diferentes relatórios. Segundo o executivo, o relatório de cada área parecia grego para as outras, e todos pareciam grego para ele. Os autores explicam que cada setor da organização assume a forma de uma divisão política, com cultura, líderes e até vocabulário próprio. Isto mostra que não há gerência da informação. Os mesmos autores pesquisaram o modelo de gerenciamento de informação mais utilizado. Dentre as organizações pesquisadas, o feudalismo foi o modelo político praticado com maior freqüência, onde cada executivo controla a aquisição e distribuição de informações de sua área, decidindo também quais informações e de que forma serão passadas ao "rei” (presidente) da organização.

De acordo com INMON (1997), a maioria das empresas possui a chamada arquitetura de desenvolvimento espontâneo, que ocorre quando uma organização adota a postura de deixar acontecer, em relação à arquitetura de hardware e software. Nestas empresas, mais e mais sistemas são desenvolvidos isoladamente, e, para o levantamento de dados comuns, muito tempo e dinheiro são gastos, e mesmo assim, resultam em informações nem sempre úteis.

PRAHALAD \& KRISHMAN (1999) escrevem que os sistemas de informação estão tornando-se rapidamente o sistema nervoso central das empresas, mas muitos gerentes não estão tratando de forma correta um assunto tão importante. Como resultado, muitas empresas acumulam um grande número de sistemas incompatíveis, projetados para atender a mesma aplicação. A vantagem competitiva não depende somente da natureza e sofisticação do software, mas de toda a infra-estrutura de informação da empresa. Várias delas acumulam 
uma quantidade grande de dados, em vários sistemas diferentes, muitas vezes sobre o mesmo assunto ou assuntos semelhantes, mas não conseguem utilizá-los de forma satisfatória, pois os sistema são incompatíveis. Os sistemas legados são um grande problemas para as empresas, e mesmo que estas trabalhem para reduzir o número de sistemas legados, muitas ainda terão que conviver com eles.

Vários autores e reportagens citam o problema da diversidade de sistemas. LACHTERMACHER (1999) exemplifica o problema, citando a Santista Alimentos, onde cada gerente trabalhava com a base de dados de seu departamento, e a empresa usava informações desencontradas sobre o mesmo assunto. ERP - Mantenha-o simples, (1999) cita a empresa farmacêutica Endo Pharmaceuticals, que não conseguia fornecer aos executivos os dados necessários à condução do negócio, pois dependia de uma dúzia de sistemas legados não integrados, o que acarretava relatórios comerciais somente no final do mês, e os executivos não tinham visão contínua do negócio. AMERICANO (1999) cita a empresa Votorantim de mineração e metalurgia, que passou por um processo de integração de seus processos e sistemas. A tarefa não foi simples, pois a empresa possuia um legado tecnológico complexo e ultrapassado, onde três modelos diferentes de sistemas compunham uma "colcha de retalhos", com programas em Cobol, pacotes de prateleira e terceirização de processamento. PASSO a passo (2000) cita o caso de uma empresa de móveis de escritório, a Italma, onde a premência por uma sistema integrado e confiável estava enlouquecendo a área de informática. Segundo o diretor de informática da empresa, Emílio Augusto, as informações estavam retalhadas em muitas bases de dados, nos diversos sistemas departamentais, os quais estavam desacreditados. FLORENZANO (2000b) apresenta o caso de uma empresa fornecedora de energia elétrica, a Companhia Paulista de Força e Luz (CPFL), que detectou a necessidade de ganhar leveza na empresa como um todo. Porém, a quantidade de sistemas de gerência utilizados, chegando até a mais de um por departamento, contribuía exatamente para o contrário, pois havia o agravante dos sistemas não conversarem entre si, gerando uma verdadeira Babel. MAIS cedo em casa (2000) referencia uma empresa fabricante de alimentos para animais domésticos, a Royal Canin, onde os funcionários, segundo François Laurent, gerente administrativo, quando tinham que elaborar relatórios para a matriz, trabalhavam até mais tarde por dois ou três dias para realizarem os levantamentos de dados. Isto ocorria porque havia vários sistemas desenvolvidos internamente, que não se comunicavam, acarretando além da grande demora, enormes dificuldades de realizar análises nos dados. QUALIDADE dos dados no centro das atenções (1999), cita a General Motors, a grande montadora que está integrando milhares de bancos de dados de clientes, de inúmeras unidades de negócio, visando melhorar a qualidade dos 
dados. Um dos responsáveis pelo projeto, Jim Noble, classifica o projeto como uma "grande dor de cabeça". Apesar do grande trabalho demandado, a busca pela qualidade dos dados dos clientes está entre a prioridade de muitas empresas. A reportagem cita uma pesquisa, que avaliou que até o ano de 2000,81\% dos diretores de informática colocavam a melhoria na qualidade dos dados dos clientes como prioridade. A reportagem também cita uma cadeia de lojas norte americana, a Sears, que tenta aumentar as oportunidades de vendas através de análises dos dados dos vários negócios, como varejo, catálogo, crédito, comércio eletrônico, entre outros. Como cada negócio possui seu próprio sistema, torna-se impossível a elaboração de uma lista única de clientes. QUEM quer dinheiro ??? (2001) cita uma empresa de entretenimento, o grupo Silvio Santos, que apresenta erros e duplicações em seus bancos de dados, uma vez que são originados de várias fontes. Estes erros e duplicações fazem com que a empresa perca tempo e recursos financeiros, como por exemplo, com correspondência errôneas. SCAGLIA (2000) apresenta o exemplo da Johnson \& Johnson, que sempre deu autonomia para suas subsidiárias, inclusive na área de informática. Porém esta autonomia resultou em heterogeneidade de processos e tecnologia, tornando impossível, obter-se uma visão global da corporação. A filial brasileira possuia vários sistemas desenvolvidos internamente e outros tantos pacotes de mercado, levando a uma teia de tecnologias que não se integravam, criando enormes dificuldades para e empresa operar com uma solução integrada.

SCAGLIA (1999) afirma que em muitas empresas, o call center (central de atendimento ao cliente) é a primeira, e muitas vezes, a única forma de contato direto com os clientes, que por estarem mais exigentes e conscientes, requerem um atendimento de qualidade. $\mathrm{O}$ autor afirma que a integração da central de atendimento aos demais sistemas corporativos, é crucial. Os departamentos da corporação não podem ficar isolados, pois os atendentes devem ter acesso rápido e irrestrito a todos os dados dos clientes.

HEHN (1999) afirma que possuir todos os sistemas de uma empresa integrados e partilhando a mesma base de dados é um avanço importante. Neste ambiente, os dados são digitados apenas uma vez e ficam disponíveis para todos, eliminando o conhecido e irritante problema de uma mesma informação aparecer com valores diferentes em diversos relatórios, pois cada um foi gerado por bases distintas.

Percebe-se uma total falta de integração informacional entre as áreas das organizações, o que prejudica enormemente uma gestão em busca da competitividade. Dessa forma, as informações são pouco utilizadas de forma estratégica. Para o uso operacional e departamental, elas são suficientes; porém, as análises em níveis mais altos, que exijam 
informações de vários departamentos ou de períodos de informatização diferentes, ficam impossibilitadas.

Comprovando a necessidade dos administradores de enxergarem a empresa como um todo, como um sistema interligado, ECHEVESTE (1999) apresenta um estudo em que os executivos das 500 maiores empresas brasileiras, classificadas pela Revista Exame em 1997, mensuraram a importância de 48 atributos no trabalho administrativo. $\mathrm{O}$ quinto atributo julgado mais importante pelos executivos, dentre os 48 apresentados, foi visão de empresa, ou seja, a capacidade de analisar a empresa como um todo. SILVA(1998) afirma que a Associação Nacional dos Cursos de Graduação em Administração (ANGRAD), através de uma pesquisa, concluiu que uma das habilidades do administrador, é compreender o todo administrativo, de modo integrado, sistêmico e estratégico, bem como suas relações com o ambiente externo. A diversidade de sistemas, não permite esta visão sistêmica da empresa.

Como mostrado anteriormente, as organizações apresentam três níveis de decisão, do mais alto para o mais baixo nível: estratégico, tático e operacional. Com a incapacidade dos sistemas de informação, de oferecem informações integradas de toda a organização, quanto mais alto for o nível da decisão, mais prejudicado será o decisor por estes sistemas, já que ele não conseguirá ter uma visão integrada da organização. Mesmo quando uma decisão é de nível mais baixo, nas organizações que apresentam estes tipos de sistema, o decisor também pode ser muito prejudicado. Ao longo dos anos, mesmo em um único departamento, vários sistemas são desenvolvidos. Chega-se à uma situação em que, mesmo em um único departamento, as informações estão espalhadas por diferentes sistemas, desenvolvidos em diferentes épocas, por diferentes profissionais e em diferentes formatos. Resultado: o acesso direto, aos dados históricos torna-se impossível. STÁBILE \& CAZARINI (2000a) abordam este problema, colocando que em um mercado altamente competitivo e de forte concorrência, as organizações estão conscientes de que a informação é um recurso valioso, porém, a dificuldade de acesso às informações estratégicas, enfrentada pelo alto escalão da maioria das organizações, é um paradoxo.

$\mathrm{O}$ administrador é um profissional diferenciado na organização. Diferentemente dos profissionais operacionais, que possuem necessidades informacionais mais estáticas e mais restritas a um departamento ou a períodos de tempo mais curtos, com grande freqüência, o administrador necessita analisar a organização como um todo e em períodos mais longos. Os vários sistemas departamentais, desenvolvidos em épocas diferentes, por profissionais diferentes e em linguagens e plataformas diferentes, não conseguem fornecer uma visão integrada das informações ao administrador. Uma organização pode ser abordada como sendo um único e contínuo fluxo de informação, que atravessa os vários departamentos, e 
onde estes atuam como produtores e consumidores de informação, conforme ilustra a figura 18:

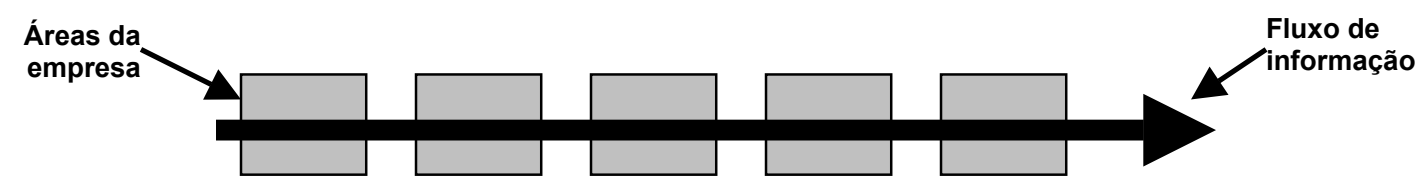

Figura 18 - A empresa vista como um fluxo único de informação

A incompatibilidade dos sistemas de informação atuam como barreiras ao fluxo de informação, prejudicando seriamente o trabalho das pessoas, principalmente, o trabalho dos administradores.

\subsection{Informações de qualidade?}

A definição de informação apresentada por EPSTEIN (1988), é que a informação é a redução de incerteza oferecida quando se tem uma pergunta. Quando a organização possui os problemas aqui apresentados dos sistemas de informação, os administradores não os usam, pois eles correm o risco de verem sua incerteza aumentada, de receberem informações erradas ou fora do tempo desejado. Assim, os sistemas de informação podem atrapalhar o desempenho profissional dos administradores.

BEUREN (1998) explica que deve haver um nível ótimo de geração de informações e acrescenta que existe uma enorme preocupação em disponibilizar informações cada vez mais sem definir e restringir seu público alvo e que a informação só será útil se atender às necessidades do usuário. A mesma autora ainda explica que a reduzida integração da área de sistemas com as áreas usuárias, resulta na disponibilização de um conjunto de dados sem analisar se este satisfaz às necessidades do usuário e que quanto maior a quantidade de informações, menor o valor destas. ALVIM (1998) escreve que, na escala de agregação do conhecimento a bens e serviços, o primeiro estágio é identificar, coletar organizar e tratar dados, transformando-os em informação. Se existe a desconexão entre consumidor e produtor, este primeiro estágio citado pelo autor, é grandemente prejudicado, o que compromete todo o processo restante. PRAHALAD \& KRISHMAN (1999) percebem através de seus trabalhos que, existe uma ligação direta entre a infra-estrutura de informática da empresas - em particular a qualidade de seus softwares - e a qualidade e a velocidade das decisões gerenciais.

BATTAGLIA (1999) aborda os sistemas de inteligência competitiva. Um sistema deste tipo, coleta informações e as disponibiliza na velocidade e no formato adequado, 
transformando-as em inteligência para os tomadores de decisão. Segundo o autor, a etapa mais importante do processo de inteligência competitiva é o planejamento e coordenação, quando são levantadas as necessidades de informações estratégicas para estruturar o próprio sistema de inteligência competitiva, ou seja, quem serão os usuários e quais suas necessidades para o processo decisório. WANDERLEY (1999), também aborda a disponibilização de informações como inteligência para os decisores organizacionais, e afirma que uma das etapas do processo, é o planejamento, momento em que se define a base para o sistema de informações. $O$ autor afirma que é importante a participação da alta gerência com o objetivo de melhor atendimento às necessidades da empresa, pois nesta fase, as necessidades informacionais dos usuários devem ser levantadas de forma correta. Percebe-se aqui, que se a ligação entre os desenvolvedores e os usuários não for satisfatória, todo o sistema será comprometido.

A tabela 17 lista problemas e conseqüências da geração de informação para os administradores, segundo CAVALCANTI (1995):

Tabela 17 - Problemas e conseqüências da geração de informação para o administrador - CAVALCANTI (1995)

\begin{tabular}{|l|l|}
\hline \multicolumn{1}{|c|}{ Problema } & \multicolumn{1}{|c|}{ Conseqüência } \\
\hline $\begin{array}{l}\text { A demora ocorrida entre a necessidade dos } \\
\text { relatórios por parte do administrador e sua } \\
\text { disponibilidade }\end{array}$ & $\begin{array}{l}\text { O resultado de uma decisão tardia poderá } \\
\text { trazer prejuízos para a organização }\end{array}$ \\
\hline Possibilidade de erros & $\begin{array}{l}\text { Relatório impreciso pode resultar em } \\
\text { decisão errada }\end{array}$ \\
\hline $\begin{array}{l}\text { Completa impossibilidade de atender a a } \\
\text { administração com relatórios de exceção }\end{array}$ & $\begin{array}{l}\text { O administrador irá perder tempo analisando } \\
\text { relatórios extensos e deixará de se dedicar a } \\
\text { outras tarefas mais importantes }\end{array}$ \\
\hline $\begin{array}{l}\text { Completa impossibilidade de atender a a admina de } \\
\text { administração com relatórios de auditoria }\end{array}$ & $\begin{array}{l}\text { A administração perderá a chance de } \\
\text { detectar rapidamente desvios, erros ou } \\
\text { mesmo má fé }\end{array}$ \\
\hline $\begin{array}{l}\text { O tempo decorrido entre a necessidade de } \\
\text { um novo relatório classificado em uma outra } \\
\text { ordem ou outro agrupamento como premissa } \\
\text { para uma possível nova decisão }\end{array}$ & $\begin{array}{l}\text { O resultado de uma decisão tardia poderá } \\
\text { trazer prejuízos para a organização }\end{array}$ \\
\hline A demora em processar o pedido do cliente & $\begin{array}{l}\text { Prejuízo em dobro: cliente recebe com atraso } \\
\text { e dinheiro entra com atraso }\end{array}$ \\
\hline Falta de controle apurado das transações & $\begin{array}{l}\text { Impossibilidade de fiscalizar o cumprimento } \\
\text { de políticas de vendas }\end{array}$ \\
\hline Dificuldade em fazer simulações & $\begin{array}{l}\text { Retardo de decisões por demora nas } \\
\text { simulações envolvendo situações futuras. }\end{array}$ \\
\hline
\end{tabular}

Considerando a informação útil como aquela que se adequa ao contexto do usuário, e que é fornecida no tempo e no formato desejados, nas organizações que apresentem 
desconexão entre usuários e desenvolvedores, dificilmente os primeiros terão informações de qualidade fornecidas pelos sistemas de informação. É muito difícil para os desenvolvedores, fornecerem soluções satisfatórias sem conhecer corretamente as necessidades dos usuários.

\subsection{Considerações finais do capítulo 5}

Neste capítulo, foi apresentado como a desconexão entre usuários e desenvolvedores de sistemas de informação, interfere na obtenção de informação pelo decisor organizacional. Mais especificadamente, foram abordados a interferência dos três aspectos apresentados no capítulo 4: o enfoque operacional, enfoque tecnológico e a diversidade de sistemas. Percebe-se que, os sistemas de informação, quando apresentam estes problemas, atuam na contramão da competitividade, pois, ao invés de fornecerem informações úteis à condução do negócio, apresentam grande dificuldade de acesso às informações importantes pelos administradores. 


\section{Capítulo 6 - Aspectos de}

\section{aproximação entre usuários e desenvolvedores}

\subsection{Considerações iniciais}

Neste capítulo, são apresentados aspectos de aproximação entre usuários e desenvolvedores de sistema de informação, visando melhorias no desempenho da informática nas organizações. Este trabalho propõe a seguinte estruturação dos vários aspectos abordados:

- o perfil do profissional de informática exigido para uma melhor interação com os usuários;

- $\quad$ aspectos humanos nas implementações;

- integração dos sistemas;

- envolvimento do usuário;

- administração da informática.

\subsection{O perfil do profissional de informática}

MOREIRA, P. (1999) pesquisou o perfil exigido dos profissionais de informática no atual mercado. As empresas consultadas pelo autor foram EDS, Running, J.D. Edwards, Microsiga, DRM e Progress, e no geral, as seguinte características foram definidas:

- conhecimentos relacionados ao negócio do cliente que estão atendendo, além dos conhecimentos técnicos inerentes ao ambiente tecnológico em que estão atuando;

- $\quad$ visão empresarial e de gestão de negócio;

- excelente relacionamento interpessoal e clareza para transmitir idéias;

- conhecimento das necessidades e do perfil do cliente;

- ótima comunicação, apto a mudanças e a negociações;

- integrador do negócio à tecnologia.

O AMBIENTE do projeto de TI e a relação entre as áreas envolvidas (1999), realizou uma mesa redonda sobre gerenciamento de projetos de informática com participantes da Varig, IBM, EDS, HP e AC Engenharia. É possível realizar o seguinte apanhado dos assuntos abordados: 
- os projetos de informática possuem três dimensões, comportamental, gerencial e tecnológica, porém, em geral, os projetos são focados apenas na dimensão tecnológica;

- para entregar o que o usuário quer, deve-se entender sua necessidade;

- o usuário deve ser aliado desde o início do projeto;

- os desenvolvedores devem compreender bem os requisitos do negócio;

- deve haver bom relacionamento das duas áreas, pois cada uma sabe um pedaço do problema, e cada uma tem um pedaço da solução;

- deve haver a presença de um profissional integrador entre as áreas;

- o gerente do projeto deve ser um bom comunicador.

BELLOQUIM (1999a) afirma que habilidades se obtêm na prática e sugere aos profissionais de informática que participem de projetos piloto de novas tecnologias, e variem constantemente de área, de modo a aprender a dominar as diversas tecnologias usadas na empresa e as várias áreas de negócio atendidas. CHERMONT (1999) afirma que muito especialistas garantem que projetos falham por motivos não técnicos, mas de recursos humanos. Assim, segundo a autora, o profissional de informática deve ter uma visão global da empresa e ser generalista. Neste ambiente, o analista de negócios, profissional que faz a ligação entre as áreas usuárias e a informática, surge num cenário multidisciplinar, buscando qualidade e flexibilidade.

\subsection{Aspectos humanos nas implementações}

As empresas estão implantando sistemas integrados de gestão, visando os benefícios em utilizar um sistema único que englobe todos os processos organizacionais. Porém, segundo HEHN (1999), o software de integração de uma empresa é apenas o instrumento, não a integração em si, pois a integração real ocorre entre as pessoas. O autor, em seu livro, que mostra como trabalhar o fator humano na implementação destes sistemas, afirma que padrões de comportamento enraizados nas pessoas da organização, não são alterados apenas com a implementação de um sistema de informação, e aponta erros comuns em projetos de informática:

- não envolver determinadas pessoas ou grupos críticos para o sucesso da implementação;

- não realizar as comunicações necessárias, permitindo o surgimento de boatos e distorções que proliferam pela companhia;

- não preparar adequadamente as pessoas;

- abusar do uso do poder e impor soluções; 
- predominância do enfoque técnico sobre o humano;

- geração de ansiedades prematuras e expectativas irreais, como a de que o sistema será a solução milagrosa e definitiva para todos os males da organização;

- não envolvimento da direção;

- concentração de responsabilidades em uma única pessoa;

- imediatismo em tentar realizar tudo ao mesmo tempo.

$\mathrm{O}$ autor escreve que, pessoas contrárias às mudanças ou a um projeto, agem das mais variadas formas, explícitas ou disfarçadas, para barrar o processo de implementação, e com o propósito de manter sua auto-estima, atacam ou resistem a um projeto, quando:

- foram deixadas de lado ou não se sentiram diretamente envolvidas no projeto;

- manifestaram-se contra o projeto e foram vencidas;

- sentiram que, de alguma forma, elas perderam prestígio, reconhecimento ou poder com o sucesso do sistema;

- $\quad$ sentem que o sucesso do projeto trará mais prestígio para outras pessoas;

- percebem as pessoas envolvidas no projeto como concorrentes internos ou ameaças.

$\mathrm{O}$ autor afirma que mudar normalmente implica em sair da zona de conforto, onde a memória é o instrumento mais usado para agir e ter sucesso, e entrar em uma região onde é preciso aprender, criar e pensar. Segundo o autor, para que as pessoas construam um balanço positivo em relação à implantação do projeto, é importante:

- envolvimento: quando a pessoa é diretamente envolvida no projeto, ela percebe que perderá menos se o projeto fracassar, e terá ganhos se o projeto triunfar. Deve-se mantê-la informada e envolvê-la nos trabalhos, atribuindo-lhe papéis e responsabilidades;

- remoção de receios: principalmente os imaginários, pois grande parte dos medos vem da ignorância. Sem informações claras sobre o projeto, as pessoas criam suas próprias informações, e daí surgem as correntes pessimistas;

- fortalecimento da necessidade de mudar: as pessoas devem entender a razão da mudança, por que ela é importante e perceber como ela contribuirá para o sucesso da empresa.

Segundo o autor, é ilusão acreditar que através do poder e da autoridade, conseguese lidar com resistências ou mecanismos de sabotagem. Uma organização transforma-se quando sua dinâmica organizacional muda, ou seja, modelos mentais, crenças e paradigmas são substituídos, a lógica de elementos estruturais é alterada, novos padrões de comportamento são estimulados e os resultados alcançados são diferentes. Dessa forma, a 
organização muda em suas entranhas, e não superficialmente, como no efeito cadeira de balanço. Para-se obter sucesso nesta alteração, é necessário atuar no todo e não, em apenas uma parte do mecanismo sistêmico, já que os esforços puramente técnicos, organizacionais ou comportamentais falham.

WAH (2000) cita o projeto de gestão do conhecimento da Xerox, prática que visa agregar valor à informação e distribui-la de forma coerente pela empresa. Neste exemplo, a solução não é apenas de máquinas e tecnologias, ao contrário: $90 \%$ é processo social e, apenas $10 \%$, infra-estrutura. A autora estudou vários casos de sucesso da prática e verificou que estes não se apóiam somente em soluções tecnológicas. Estas empresas reconhecem a importância do elemento social do relacionamento humano e sabem que precisam superar vários obstáculos culturais e comportamentais. SLATER (2000) afirma que no processo de alinhamento da informática à estratégia da empresa, observa-se que a tecnologia sozinha não faz nada, e que, na verdade, tudo se resume às pessoas.

JENSEN (1998) afirma que, em qualquer auditoria de mudanças organizacionais, observa-se que uma das três necessidades principais de uma empresa é sempre melhorar a comunicação. A transmissão e a organização da informação relativa ao trabalho é a terceira maior fonte de complexidade e causa do fracasso de implantação, segundo o estudo sobre complexidade. $\mathrm{O}$ autor cita a queixa de um diretor em um momento de frustração: tudo seria muito simples, se não fossem as pessoas. JIANG et al. (2000) afirmam que um fator chave, em muitas implementações problemáticas de sistemas de informação, é a resistência do usuário à mudança. Através de uma pesquisa, os autores levantaram as razões da resistência dos usuários aos sistemas de informação:

- mudança no conteúdo do trabalho;

- perda de status ou poder;

- relacionamentos alterados;

- mudanças no processo decisório;

- incerteza e insegurança.

Na mesma pesquisa, os autores definem as três maneiras mais eficazes de promover a aceitação dos sistemas de informação entre os usuários:

- envolvimento dos usuários;

- comunicação aberta;

- informações sobre as mudanças.

\subsection{Integração dos sistemas}


BELLOQUIM (1997) afirma que precisamos de uma arquitetura de sistemas de informação planejada e construída com inteligência, que a torne menos suscetível à inovações tecnológicas; arquiteturas nas quais possamos introduzir novas tecnologias com o mínimo de ruptura. $\mathrm{O}$ autor afirma que este tipo de arquitetura depende mais de planejamento e controle inteligentes do que de qualquer tecnologia de conectividade. $\mathrm{O}$ objetivo é que todos os novos sistemas devem ser projetados para se encaixarem harmoniosamente nos já existentes e permitirem conexões com futuros sistemas. $\mathrm{O}$ autor sugere que na compra de um pacote, além do preço e da funcionalidade, deve ser observada a integração deste aos demais sistemas da empresa: às vezes é mais interessante comprar um sistema com menos funcionalidades, porém integrável, a um pacote completo, porém incompatível com as demais aplicações da empresa. Segundo o autor, para construir uma arquitetura integrada, pode-se recorrer aos conceitos da orientação objeto: se fosse possível construir novos sistemas e encapsular os sistemas legados como objetos, a comunicação entre eles seria mais fácil; assim, cada parte forneceria serviços bem definidos a quem precisasse, através de uma interface bem documentada. Toda empresa pode planejar a integração coerente de todas as suas peças: com um mapa geral, mostrando como as coisas devem se encaixar umas nas outras, ficará mais fácil escolher tecnologias que sirvam de “cola”. Será mais fácil também, entender onde devem ser encaixadas as novas tecnologias, impedindo uma adoção sem planejamento que fatalmente, causará problemas no futuro.

FLORENZANO (2000c) cita o projeto Multibroker, portal que reunirá 22 corretoras do Rio e de São Paulo. Luis Paulo Prodomo, coordenador do projeto, afirma que na integração de diferentes ambientes de informática com novos aplicativos para Internet, os padrões tecnológicos não são os únicos e nem os principais obstáculos. A qualidade da mão de obra é um ponto fundamental. A autora cita três aspectos principais sobre integração:

- há mais problemas do que soluções quando o tema é integração;

- tecnologia só não resolve, pois as pessoas são a base de tudo;

- a solução adotada deve ser flexível e prever crescimento.

SLATER (2000) afirma que a montadora Ford concentra seu trabalho na padronização e integração de sua tecnologia de desenvolvimento de produtos, num só programa de gerenciamento de informação. Essa padronização reduziu o tempo médio de desenvolvimento de alguns produtos de 37 meses para 24. CRIE uma arquitetura vencedora (1999), afirma que estruturas corporativas padronizadas e flexíveis, produzem inúmeros benefícios para a área de informática. Com um projeto bem montado e apropriado, uma empresa pode explorar com sucesso seu ambiente de informática para alavancar os negócios. Dentre os benefícios, a reportagem aponta: 
- disponibilização mais rápida de novos aplicativos;

- melhor retorno dos investimentos em sistemas legados;

- facilidade na integração de soluções diversas;

- melhor interoperabilidade de dados;

- maior flexibilidade em processos de aquisições e fusões.

De acordo com a reportagem, fundamentalmente, o processo de planejamento da arquitetura comercial examina a situação do negócio e da informática, e desenvolve uma visão integrada do ponto a se dirigir, visando assegurar que os investimentos em informática fiquem alinhados com a estratégia comercial.

\subsection{Envolvimento do usuário}

BARBIERI (1999) afirma que é cada vez maior a presença de profissionais das áreas usuárias nas equipes de sistemas, e que restará, aos analistas de sistemas, realizarem o meio campo entre negócios e informática. SILVA (1997) afirma que a participação do usuário na especificação dos requisitos, das características operacionais, da interface homem/aplicativo, dos controles internos e de outros atributos, é fundamental para o sucesso de um sistema de informação. FARRE (2001) afirma que existem vários produtos que fornecem uma plataforma colaborativa, e um conjunto de ferramentas para ajudar os diversos profissionais a obterem o input dos usuários nos projetos de software. Com estes produtos, é possível criar uma especificação das exigências, em forma de documento, para gerenciar a implementação das mesmas, mudanças e testes, através do ciclo de vida do software. O autor cita como exemplo, o Complete Business Solutions, um integrador de sistemas que oferece um serviço de desenvolvimento de aplicativos com 1500 desenvolvedores na Índia, que administram teste de unidade, código e projeto de software. Em um dos projetos atuais, o cliente recebe interações progressivas a cada duas semanas, durante um ano, o que evita surpresas, pois quando do término do projeto, o cliente já analisou o software com grande freqüência. A empresa Cygent, provedora de serviços para a indústria de comunicação, obteve grande êxito em seus últimos projetos, e seus profissionais afirmam que este tipo de ferramenta acelera o processo de desenvolvimento e assegura que o produto final atenda a todas as exigências e aos prazos. A Landmark Graphics, desenvolvedora para indústria de petróleo, consegue economizar tempo e dinheiro com novos projetos, por ter documentado as exigências dos lançamentos anteriores, um vez que o software de gerenciamento de exigências facilita suas mudanças de um lançamento para outro.

SONDA et al. (2000), em um estudo de caso com a aplicação de um método de coleta de requisitos, observaram que a definição antecipada das características principais do 
sistema é fundamental para o desenvolvimento de um software. DALE \& MACHOWSKI (1999) apud SONDA et al. (2000), concluem que os esforços devem ser concentrados na coleta de informações qualificadas referentes à definição do produto (fases iniciais de desenvolvimento do software). De acordo com SONDA et al. (2000) ouvir os clientes é essencial no desenvolvimento de produtos, mas nem sempre é fácil traduzir para o produto os desejos dos consumidores, pois muitas vezes a linguagem utilizada não se adapta diretamente às especificações técnicas. O estudo evidencia que a etapas iniciais do desenvolvimento do software (análise de atributos do sistema e projeto do produto) devem ser priorizadas. Este fato coincide com a prática defendida pela maior parte dos autores de engenharia de software, que pregam que um esforço maior deve ser feito nas fases iniciais de desenvolvimento, evitando retrabalhos futuros. O processo que mobiliza mais recursos é o desenvolvimento do produto, e isto evidencia ainda mais a importância das fases anteriores análise dos atributos do sistema e projeto do produto. Erros nestas fases implicam retrabalho na etapa de desenvolvimento, que é mais cara. O estudo conclui também que a pesquisa de mercado é uma ferramenta importante, que pode revelar detalhes desconhecidos para a equipe. No início do projeto a equipe achava que sabia qual o produto a ser desenvolvido, mas após ouvir a voz do cliente, a concepção do produto alterou-se substancialmente. Tornase, pois, imperativo ouvir a voz do cliente. Os autores afirmam que normalmente, os analistas de sistemas privilegiam as características técnicas dos produtos, uma visão limitada, que freqüentemente não contempla o universo de características valorizadas pelos usuário.

LOZINSKY (1998) coloca que, entre inúmeras questões nas implantações de sistemas integrados de gestão, a mais importante é a equipe do projeto, que deve contar com especialistas e usuários de todas as áreas envolvidas, pois as pessoas fazem toda a diferença. É essencial que todas as funções de negócio que tenham alguma relação com o sistema, estejam representadas no projeto de forma adequada, de modo a garantir o comprometimento de cada uma dessas áreas e permitir avaliar, com critério, o impacto real que o sistema terá em cada função de negócio. VALENTE (1999) afirma que as organizações estão percebendo que o problema de desenvolvimento e manutenção de software não está na tecnologia utilizada, mas na incapacidade de gerenciar o processo de desenvolvimento de software. Segundo o autor, uma boa especificação dos requisitos, permite o desenvolvimento de produtos que refletem as necessidades reais dos clientes, aumentando sua satisfação, e um bom planejamento e acompanhamento do projeto, permitem melhor previsibilidade no desenvolvimento do software. Além disso, métricas de projetos anteriores e similares proporcionam melhores estimativas da duração do projeto e, conseqüentemente, do seu custo. 
FEENY \& WILLCOCKS (1998) através de um estudo, concluíram que o investimento na construção de uma diálogo mais amplo, entre a empresa e a comunidade de informática, faz o usuário compreender o potencial da área, ajudando-o a trabalhar junto com os técnicos e garantindo um sentimento de posse e satisfação. Porém pesquisadores afirmam que há uma dificuldade inerente a este diálogo: a diferença cultural entre técnicos e usuários. Mesmo assim, os autores percebem que a criação de relacionamentos desenvolve a confiança mútua, identidade de propósitos e comunicação bem sucedida. Investimentos devem ser feitos em treinamento e informação, visando a criação de uma diálogo produtivo entre pessoas que antes tinham dificuldade para conversar. Eles concluem, pela pesquisa, que qualquer projeto significativo deve ser da empresa e não da área de informática, exigindo um patrocinador, um defensor e um gerente, estando os dois primeiros no alto escalão. $\mathrm{Na}$ adoção de novas tecnologias, as implementações são mais eficientes se feitas por equipes multifuncionais lideradas pelos usuários dentro da empresa. Sobre os conflitos e preconceitos que ocorrem com freqüência entre a área de informática e as áreas usuárias, GAUSE \& WEINBERG (1991), afirmam que a melhor forma de evitá-los, é fazer, inicialmente, com que as partes se conheçam e se sintam como seres humanos, antes de trabalharem uns com os outros, cada um em seu papel profissional.

PRAHALAD \& KRISHMAN (1999) afirmam que técnicos e usuários devem compartilhar seus conhecimentos o máximo possível, visando uma infra-estrutura de informação robusta. Muitas decisões críticas são tomadas nos processos de desenvolvimento de sistemas, e o departamento de informática não pode ficar isolado. É crucial que os demais departamentos envolvam-se e compartilhem conhecimento. HWANG \& THORN (1999) afirmam que existe uma grande correlação entre o envolvimento do usuário no desenvolvimento de sistemas e o sucesso destes, e sugerem, aos desenvolvedores, que adotem esta prática visando o aumento do sucesso de seus sistemas. CHEN et al. (2000) através de um estudo, mostram que a satisfação do usuário final com o data warehouse, depende do suporte provido pelo pessoal de informática. Pode-se estender os achados dos autores para outros tipos de sistemas e perceber que a proximidade entre as áreas e a integração de seus profissionais, é de suma importância.

No atual ambiente concorrencial, as empresas necessitam de sistemas de informações eficientes para o gerenciamento das relações com os clientes. WELLS et al. (1999) afirmam que, existe uma lacuna entre as perspectivas da área de informática e da área de marketing, sobre como uma organização deve projetar um sistema de informação dos clientes. As duas áreas devem trabalhar juntas com um alto grau de coordenação para produzirem uma solução conjunta. Os autores citam como elemento chave, entre outros, para 
um sistema de informação de clientes, a criação de uma estratégia para a coleta das informações e a integração e redesenho dos dados através da organização. Outro elemento crucial, segundo os autores, é a acessibilidade da informação organizacional: se as informações não estão integradas e disponíveis aos funcionários, não haverá efetiva interação com o cliente. Os autores citam os casos da Levi Strauss e da Ritz-Carlton, que envolveram suas áreas de informática nas atividades de reengenharia dos processos, visando maior integração entre os participantes, e se empenharam na integração dos dados para criação de uma visão integrada das informações de seus clientes.

O PAPEL do CIO (2000) cita um estudo entre executivos de informática nos EUA, onde $70 \%$ dos entrevistados afirmaram que o comércio eletrônico tem colocado seus departamentos nos processos de tomada de decisão de negócios, e quase $60 \%$ dizem que a Internet tem forçado suas áreas a liderarem reengenharias nos processos gerais das empresas. Segundo a reportagem, quando negócio e tecnologia se unem, bons resultados podem ser obtidos, e o estudo mostra que as partes estão trabalhando mais unidas, ao contrário do passado. ALBERTIN \& MOURA (1995), em um estudo sobre a área de informática entre instituições bancárias nacionais, afirmam que deve haver a participação da área na organização, traduzida na proximidade com as áreas usuárias, com a organização e com o ambiente do próprio negócio, visando:

- priorização coerente com a organização;

- definição dos problemas de forma mais completa;

- especificações de soluções para os problemas reais, em conjunto com os usuários;

- adequação da velocidade da informática com a organização;

- obtenção de uma visão de mercado e dos clientes da organização;

- estabelecimento de uma postura voltada também para o negócio e não apenas para assuntos técnicos.

Sobre a necessidade do relacionamento da área de informática com os usuários, os autores afirmam que esta deve existir devido à:

- necessidades constantes de contatos com os usuários;

- negociação de prioridades e prazos;

- obtenção de compromissos entre os envolvidos;

- administração do próprio trabalho, devido à autonomia exigida por suas características;

- especificação de problemas e soluções que envolvem aspectos sociais;

- identificação e obtenção de requisitos e informações. 
LACHTERMACHER (1999) cita o caso da Promom, uma das maiores empresas brasileiras de engenharia, que, visando maior eficiência, criou os facilitadores de informática, representantes de cada área usuária que fazem sua ligação com a área de informática. $\mathrm{O}$ facilitador passa a ser uma fonte de informação para a área de sistemas, o que é diferente do pessoal de sistema buscar estas informações. Na mesma empresa, cada novo projeto passa por uma discussão ampla para, a partir daí, se fazer a análise para aprovação ou não do projeto. A autora também cita a Natura, indústria brasileira de cosméticos, onde a relação entre usuários e técnicos acontece através de um comitê, em que participam o presidente da empresa, os principais diretores das áreas usuárias e o pessoal de informática. Dessa forma, a tecnologia é estabelecida pelos usuários e, se não for assim, com a participação dos dois lados, não é considerado projeto. A autora cita algumas dicas para um bom entendimento entre a área de sistemas e os setores de negócio da companhia:

- a escolha das aplicações deve ser feita em conjunto com os usuários;

- as soluções devem ser discutidas pelos dois lados, e a informática não deve impor soluções;

- é interessante a criação de comitês para análise e aprovação de projetos;

- todos os departamentos devem conhecer bem as regras de aprovação de projetos para melhorar as discussões;

- o grupo responsável por um projeto aprovado deve conter usuários da área atendida;

- todos os projetos devem ser muito bem documentados e todos os participantes devem ter acesso a isso;

- é importante que a satisfação do usuário seja avaliada com freqüência.

SANTOS (2000) a respeito dos investimentos tecnológicos das empresas brasileiras, cita um estudo do Gartner Group, que estima que, em 2005, 50\% dos produtos e serviços oferecidos pelas empresas estarão de algum modo integrados pela Internet. Esta tendência de reestruturação de modelos organizacionais para desenvolver negócios, baseados na nova tecnologia, com certeza caberá ao profissional cujo perfil reúna conhecimentos de tecnologia e visão de negócio. Assim, os executivos de informática estão cada vez mais presentes nas reuniões de negócios. A autora cita como exemplos, os laboratório Wyeth-Whitehall, e a Orbital, empresa surgida de uma cisão da Credicard, administradora de cartões. Nestas empresas, os antigos executivos de informática estão respondendo por áreas de negócios e usando o domínio que possuem de tecnologia para alavancar estratégias. De acordo com a autora, profissionais e especialistas de mercado têm a certeza de que agora, tecnologia e negócio andam juntos. 
VILAROUCA (1999), cita a empresa americana Kendall-Jackson, onde a área de informática abraçou um projeto que cresceu até parar, e inúmeras tentativas de recomeçá-lo fracassaram. O executivo de informática que, posteriormente, assumiu o projeto, Frank Barriero, afirma que o problema foi a falta de informação das pessoas envolvidas, já que os usuários nunca haviam passado por um treinamento. A idéia dos usuários era de que o projeto era só da área de informática, e por isso, não colaboravam. Segundo o executivo, foi necessário convencê-los de que o projeto era da área usuária, e que a área de informática só estava ali para implementá-lo.

INTEGRAÇÃO é fundamental (1999), como exemplo de integração da área de informática com as demais áreas da empresa, cita a Santista Alimentos, onde o projeto de comércio eletrônico já nasceu com seu patrocinador máximo, o presidente da empresa. UM PRONTO-socorro enxuto (2000), sobre o envolvimento do usuário na implantação de sistemas de informação, cita o caso do hospital Barra D'or, no Rio de Janeiro, que modernizou seu parque tecnológico e uniformizou os dados de todas as suas áreas. De acordo com o gerente de tecnologia do hospital, Francisco Queiroga de Sá Filho, todos os funcionários foram treinados e, somente ao término do programa, as novas técnicas foram colocadas em funcionamento. O nível de aceitação foi de 100\%, e o treinamento foi visto como fundamental para um processo de mudança tão grande. SCAGLIA (2000) cita o caso do Banco BCN, em que a velha estrutura centralizada e isolada do centro de processamento de dados, está sendo reformulada para uma estrutura integrada com os negócios do banco. Segundo o diretor de informática do banco, Sérgio Sztajn, um dos segredos para o sucesso do novo modelo é a existência do gestor de projetos, o profissional que faz a ligação entre a área usuária e a equipe de informática. $\mathrm{O}$ autor cita também a Companhia de Saneamento Básico do Estado de São Paulo (Sabesp), que também passa por uma reformulação em busca de maior agilidade. A área de informática era subordinada à área financeira, mas agora passou para a área de gestão de assuntos corporativos, pois a empresa adotou uma posição mais estratégica a seu respeito. Com esta visão estratégica da direção da empresa, a área de informática ganhou credibilidade e confiança, e vem recebendo grandes investimentos. Outra empresa citada pelo autor, a Perdigão, também passou por uma reformulação, visando melhorias, e a área de informática foi dividida em duas. Uma delas, a divisão de processos e desenvolvimento, tem ligação direta com o negócio da empresa. Assim como o BCN e a Sabesp, a Perdigão criou a figura do analista de negócios, visando aproximar os profissionais de informática com os objetivos da empresa e acabar com o isolamento das partes. $\mathrm{Na}$ Perdigão, os analistas de negócio recebem constantemente grandes investimentos de treinamento, mostrando o quanto esta função é importante para a empresa que visa a 
melhoria de seus processos de negócio. A Kodak, também citada pelo autor, gigante do mercado fotográfico, mudou sua estrutura descentralizada de informática para uma estrutura única, ainda que para atender toda corporação responsável pela América Latina, visando redução de custos, menor tempo de ciclo de desenvolvimento e, principalmente, maior padronização. Estes objetivos não eram atingidos quando cada país da região possuía sua própria estrutura de informática.

SUBRAMANIAN et al. (1997) pesquisaram os esforços de integração dos dados da prefeitura da cidade americana de St. Louis, que se encontravam espalhados por diferentes plataformas e bancos de dados. Os autores perceberam que o planejamento da integração é extremamente difícil, requerendo a participação não só do pessoal de informática, mas também dos usuários, gerentes e outros superiores, todos com perspectivas e interesses heterogêneos.

\subsection{Administração da informática}

BOTTINO (1997) afirma que está cada dia mais complicado administrar o cotidiano da informática na empresa, pois as novidades, em todos os campos, são muito freqüentes. Como não se pode fugir desta contínua evolução, o melhor a fazer é avaliar os impactos que as novas tecnologias trarão para a empresa. Em seguida, planejar cuidadosamente sua implantação, principalmente aquelas que têm potencial para afetar o negócio. Segundo o autor, para minimizar as reações adversas do usuários nos processos de migração, que podem até comprometer o processo, palestras antecipando as vantagens do novo ambiente e as estratégias para a migração devem ser promovidas.

MOTTA (1998) levanta algumas questões visando apontar caminhos de melhorias para a informática nas empresas:

- não usar a informática para substituir a competência - é comum ver empresas tentando alcançar objetivos através da informática, que só seriam alcançados através de uma gerência competente. A informática apenas fornece instrumentos, mas se a gerência estiver errada, pouco ela pode fazer. É comum as áreas de negócio reclamarem da falta de resultados da área de informática. Porém, poucas áreas de informática têm peso e conhecimento necessários para reclamar das áreas de negócio;

- adotar padrões - é uma medida difícil de tomar, mas que ajudará muito no aumento de eficiência. A principal dificuldade são os feudos existentes nas empresas que insistem em adotar soluções próprias; 
- comprar pronto, sempre que possível - os riscos de desenvolvimento de sistemas, assim como as estatísticas de problemas são grandes. A manutenção destes sistemas também causa grandes problemas às empresas;

- cautela com os benchmarkings vendidos por consultores - estudos mostram que empresas da mesma indústria e com mesmo nível de investimento em informática, apresentam retornos diferentes. A diferença está na administração dos investimentos.

PENTEADO (1999a) através de um levantamento feito com diretores de informática, consultores e analistas, mostra alguns aspectos a serem considerados na busca do sucesso em projetos de informática:

- não acreditar em milagres, pois não existe software, empresa ou tecnologia que atenda todas as necessidades dos clientes sem alterações;

- testar ao máximo e no ambiente do cliente;

- projetos de informática precisam de um responsável maior junto ao alto escalão;

- imediatismo: muitas vezes é preciso saber esperar para conseguir os benefícios;

- continuidade: não existe projeto de informática estanque; torna-se necessário sempre buscar a lucratividade da empresa;

- usuários: devem ser devidamente comunicados e treinados, para que consigam obter o máximo de benefício do projeto.

PENTEADO (1999b) apresenta um estudo realizado pela Deloitte Consulting, em conjunto com a Benchmarking Partners, que mostra algumas dicas para obtenção de melhores retornos com os sistemas integrados de gestão:

- manter o foco voltado para capacitações e benefícios, não apenas em colocar o sistema no ar. A colocação do sistema em funcionamento é somente uma das metas do projeto, não a principal;

- alinhar toda a organização com metas, para se certificar de que todos têm a mesma visão sobre as motivações que levaram ao projeto. Empresas de sucesso mantém os funcionários treinados para cada nova meta estabelecida e para as que estão por vir;

- garantir que as mudanças no pessoal, nos processos e nas tecnologias estejam em equilíbrio. Longe de ser um projeto unidimensional, um sistema integrado deve manter as mudanças equilibradas em todas as áreas, antes, durante e depois da sua colocação no ar;

- colocar pessoas que trabalham no projeto, em áreas diversas da empresa, visando a expansão do conhecimento pela troca de experiências. 
MOREIRA, G. C. (1999) afirma que, normalmente, na escolha de soluções, os usuários assistem a várias demonstrações de fornecedores diferentes e concluem que a solução é híbrida ou inexistente, pois todas as soluções possuem pontos fortes e fracos. Assim, o autor apresenta uma metodologia de escolha de aplicativos desenvolvida com o intuito de ajudar as empresas a decidirem. O planejamento de informações é a primeira fase da metodologia proposta pelo autor, quando são identificados os objetivos do negócio, as necessidades informacionais atuais e futuras, e determina como estes requisitos podem ser obtidos. Também são abordados o ambiente externo da empresa, a área de informática, seus sistemas atuais, e as oportunidades de uso da informática. Na segunda fase, entre outros critérios, torna-se necessário definir as interfaces entre os sistemas e planejar a conversão. A proposta do autor mostra que o processo de escolha é guiado pelas necessidades informacionais, e não pela tecnologia.

MATTOS (1999) cita problemas encontrados nas implantações de sistemas integrados de gestão:

- a pressa de implantar tais sistemas fez com que as empresas brasileiras aceitassem implementações rápidas, utilizando modelos standard que já vêm embutidos no sistema, adequando a empresa a esses processos e não o contrário;

- considerar a implantação do sistema como um projeto que termina na data em que entra no ar. O autor chama isto de "síndrome da data de conversão", onde todo o esforço da equipe é concentrado para a entrada do sistema no ar com sucesso, e todos ficam mergulhados na parafernália tecnológica, em detrimento dos motivadores de negócio que norteiam a decisão de implantação. Assim, a data da conversão é comemorada com festa, como se fosse o fim da batalha quando, na verdade, o projeto está apenas começando;

- a fase posterior à colocação do sistema no ar requer da alta administração metas agressivas, a disponibilização de recursos e dedicação para que as verdadeiras transformações aconteçam, caso contrário, a empresa não obterá sucesso, pois o novo sistema interfere com tradições e estruturas de poder arraigadas por muitos anos.

O autor afirma que a vantagem buscada pelas empresas com implantações de novos sistemas está na forma como a empresa alinha suas estratégias competitivas com seus processos, pessoas e tecnologia.

TREPPER (2000) afirma que uma maneira de trazer ordem ao caos, que muitas vezes impera na área de informática, e faz com que esta seja mal vista pela empresa, é empregar uma forma de controle organizacional. O gerenciamento dos processos de 
informática, através de métodos e padrões, oferece os mecanismos necessários para compartilhar as melhores práticas criadas ou descobertas pelos funcionários da área, visando o aprimoramento contínuo dos processos. Assim, um conjunto de princípios, ferramentas e técnicas para se projetar e implantar sistemas deve ser implementado. Como benefícios, têm-se a aceleração do conhecimento e diminuição de custos, pois o retrabalho e dúvidas sobre as atividades são reduzidas. A área de informática ganha mais disciplina e produtividade, visando maior sintonia com as demais áreas da empresa. Porém, o autor afirma que é preciso ter cuidado com metodologias inflexíveis, que podem engessar o processo de desenvolvimento.

HUMPHREY (2001), para mudar a atual cultura do software presente nas empresas, sugere que:

- os engenheiros sigam os processos definidos, planejados e medidos;

- todo o trabalho seja planejado antes de se chegar a um cronograma;

- os engenheiros meçam e controlem, tanto dados relativos ao seu tempo como ao tamanho e defeitos nos produtos;

- cada projeto de software seja documentado e revisto antes de ser codificado;

- a qualidade seja planejada, medida e controlada ao longo do trabalho;

- todos os trabalhos terminados sejam analisados e os resultados usados para melhorar o processo.

Segundo o autor, os programas atuais de formação em software focalizam quase totalmente as ferramentas e produtos, e é dada pouca atenção aos métodos de engenharia efetivos.

VILAROUCA (1999) apresenta a citação do gerente geral de tecnologia de informação da Philips para a América do Sul, onde afirma que o primeiro grande fracasso do diretor de informática, começa quando ele se desalinha com o negócio da empresa, e perde o apoio da alta direção. O autor também cita Mônica Lodes, diretora de informática do Boticário, a maior rede de franquias brasileira. Além da formação em computação, ela cursou pós graduações em outras áreas, como técnicas de gestão. À frente da área de informática da empresa, ela tem se especializado também em outros setores, como marketing, manufatura e controladoria, o que a ajuda no entendimento e relacionamento com o cliente. Segundo o autor, outro fator importante para o sucesso do diretor de informática, é sua relação com o cliente, interno ou externo: quanto melhor seu tratamento, mais chances de sucesso. O autor também, afirma que, segundo os especialistas da área, para que um executivo de informática seja bem sucedido, deve conhecer bem os negócios da empresa. 
INVESTIR para economizar (2000), cita uma empresa de plano de saúde, a Unimed do Rio de Janeiro, que vem investindo na integração e disponibilização de dados estratégicos para seus decisores. Sob este novo enfoque, que antes era operacional, a empresa já conseguiu identificar situações importantes através da análise dos dados, o que antes não acontecia, e atuar dessa forma na busca da competitividade.

COEN (1999) lista cinco fatores que devem ser observados pelos executivos de informática, na busca pelo sucesso, em um ambiente onde a área de informática ganha mais e mais destaque:

- visão geral do negócio, incluindo o relacionamento com fornecedores e clientes tanto internos como externos;

- boa visão do uso de novas tecnologias na empresa em que trabalha, e capacidade de calcular o retorno do investimento em novos sistemas;

- fortes conhecimentos em marketing para serem aplicados na interpretação de informações de bancos de dados e sistemas de data warehouse;

- montagem de boas equipes e gerenciamento de perfis mistos, entre técnicos e profissionais que têm maior visão do negócio;

- visão ampla de gestão de negócios em outros países, para gerenciamentos de projetos e soluções globais.

A autora cita a declaração de Paulo Ernane, diretor de informática da Fiat Brasileira, afirmando que embora esteja no mesmo nível de outros diretores, o diretor de informática é menos considerado. Para eliminar este desprestígio, segundo ele, este profissional deve desenvolver capacidade de liderança, visão de negócios e não restringir-se apenas à tecnologia. Neste sentido, uma pesquisa do Gartner Group nos EUA, apurou que, mesmo sendo a informática uma área importante para a estratégia de negócio, apenas metade das empresas pesquisadas elevou seus diretores de informática à alta administração. Segundo a autora, outra grande qualidade do diretor de informática, é olhar para fora da empresa e buscar atender às necessidades dos clientes, sugerindo investimentos que a façam mais competitiva.

VILAROUCA (1999) cita um projeto bem sucedido em uma empresa de distribuição de energia elétrica, a Asea Brown Boveri. Segundo o diretor de informática responsável pelo projeto, Carlos Airton Rodrigues, o sucesso foi o resultado de fatores como o apoio da alta administração e a participação dos usuários. BENSAOU \& EARL (1998) afirmam que os executivos estão insistindo em elevar a informática a nível estratégico, mas confessam que é uma tarefa muito difícil. A informática tem sido encarada simplesmente como tecnologia, mas agora deve ser gerenciada como arma estratégica. Os projetos 
desenvolvidos seguem o foco técnico, sem ligação com a estratégia da empresa, e a solução é desenvolver uma estratégia de informática. Os autores citam a empresa japonesa SevenEleven, que vem obtendo melhorias contínuas, porque todas as mudanças, não só as de informática, foram guiadas por necessidades dos clientes, mostrando grande foco estratégico. Os autores afirmam que, no Japão, a informática não é vista como algo especial, diferente ou problemático, mas sim como parte de uma estrutura maior, integrada, e as empresas aplicam a tecnologia apropriada não como um fim em si, mas como um meio, ao contrário do que acontece nas empresas americanas. Os autores afirmam que as empresas reclamam que os técnicos não entendem nada de negócio, pois se um executivo pede a um técnico para mostrar como usar a informática, estrategicamente, ele começa a falar sobre arquitetura de dados. Assim, empresas estão usando, para fechar a lacuna, profissionais que entendam os dois lados e façam a ligação. Muitos gerentes japoneses passam 2 ou 3 anos, mesmo contra a vontade, em departamentos de informática como parte de um rodízio, para que ele aprenda sobre os dois lados e possa usar seu conhecimento para o bem da empresa. No Japão, técnicos são colocados junto com os usuários e gerentes, melhorando a comunicação e a compreensão entre os lados, e o executivo de informática é alocado também em outras áreas da empresa, para evitar o isolamento da informática, diminuindo conflitos e aumentando a produtividade. Geralmente as empresas japonesas desenvolvem tudo internamente e possuem parcerias com um único fornecedor, proporcionando entendimento mútuo e padronização. Os autores afirmam que sistemas de informação geralmente focam o processo a ser informatizado e não, as pessoas que vão usá-lo. Como resultado, as pessoas encontram dificuldade em usá-los e acham que os sistemas só atrapalharam seu trabalho. Para evitar esta situação, nas empresas japonesas, existe uma maior envolvimento dos usuários, treinamento e suporte constantes.

BURN \& SZETO (2000) afirmam que o uso da informática na busca de competitividade nas empresas é evidente, e os profissionais dos dois lados, técnicos e usuários, percebem a necessidade de alinhar a estratégia da empresa com a informática, porém este alinhamento é visto como crítico e muito problemático pelos dois lados. A efetiva e eficiente utilização da informática requer o alinhamento desta com a estratégia de negócio. Isto reflete a visão de que o sucesso da informática depende da ligação da estratégia de negócio, estratégia de informática, processos e infra-estrutura organizacional, processos e infra-estrutura de informática. De acordo com DIAS (2000), o benefício potencial da informática não vem sendo completamente utilizado, pois o uso dela por profissionais e gerentes não tem correspondido às expectativas. $\mathrm{O}$ estudo realizado pelo autor apresenta os aspectos enfatizados pelos gerentes para o bom uso dos sistemas de informação: 
- alinhamento com o negócio da organização;

- amigáveis e fáceis de acessar;

- uso de tecnologia atualizada;

- desenvolvimento com a participação dos usuários;

- atendimento completo às necessidades dos usuários;

- treinamento dos usuários.

GILBERT (1999) afirma que muitas empresas consideram que a informática não cumpre as promessas feitas e, mesmo com sua capacidade superestimada, a culpa não é ela, mas da empresa em si mesma. O autor coloca que as organizações vencedoras usam a velocidade como arma competitiva, são mais fluidas e menos burocráticas, e as organizações convencionais, com diversas funções especializadas, não possuem a velocidade de reação necessária. Tornam-se necessárias equipes multidisciplinares, que utilizam uma base comum de informação, para desencadear ações rápidas e simultâneas. Muitas vezes, espera-se que a informática transforme estas empresas convencionais, porém a informática irá melhorar apenas processos isolados. Os sistemas departamentais operacionais, mesmo quando inovadores, sempre serão sistemas operativos, e não se pode esperar deles algo para o qual eles não foram concebidos. Quando isto ocorre a empresa decepciona-se. Já os sistemas de informação competitiva, segundo o autor, não se concentram na informática, mas na fórmula competitiva da empresa como um todo, e devem ser tocados pela alta administração em conjunto com as demais áreas da empresa. Os diretores de informação devem estar inseridos na alta administração e serem conhecedores da estratégia da empresa.

EARL (1999) afirma que todos os que foram criados na era industrial aprenderam que os recursos da empresa eram homens, máquinas, materiais e dinheiro, mas, hoje, devese acrescentar um novo recurso - a informação. Agora, todas as empresas tornam-se empresas de informação, e todos os administradores tornam-se administradores de informação. $\mathrm{O}$ autor cita problemas a serem evitados para que a empresa consiga realmente usufruir de suas informações:

- discussão acalorada entre divisões sobre a quem pertence a informação;

- discussão acalorada entre divisões sobre quem tem acesso a ela;

- formação de plataformas tecnológicas que impeçam o fluxo de informações;

- gerentes e funcionários que não tenham as habilidades de informação;

- gerentes e funcionários que não pensam em aquisição, administração e utilização de informação.

DAY (1999) escreve que a maioria das organizações não sabe o que sabe, pois ela pode ter sistemas operacionais eficientes e, ao mesmo tempo, enfrentar problemas ao tentar 
reunir todas as peças necessárias em um só lugar. Os inimigos da distribuição de informação são os departamentos que restringem o fluxo de informações. Manter o fluxo de informações ativado dentro da empresa é a chave para fluir as idéias, e nelas os decisores estão mais bem informados. As empresas estão investindo cada vez mais em informática, mas esta só fornecerá ajuda duradoura se for apoiada por processos organizacionais que promovam o aprendizado de equipe e evitem o expurgo da memória organizacional por rotatividade e transferência.

STORCK \& HILL (2000) citam o desenvolvimento de um projeto para criação e transmissão de conhecimento com mais eficácia na Xerox. Como fatores de sucesso, entre outros, os autores citam:

- âmbito estratégico e global;

- tratamento dos conflitos entre as unidades de negócio;

- $\quad$ aceitação dos altos escalões;

- utilização de uma estrutura sem autoridade hierárquica;

- padronização da linguagem entre as unidades de negócio.

ABREU et al. (1999) escrevem que é comum padronizar sistemas antes incompatíveis, transformando o fluxo de informação em um processo sem costuras, transparente. Porém, segundo os autores, o grande desafio é criar modelos administrativos que explorem estrategicamente estas interligações, e este processo passa, invariavelmente, pela forma como a organização é visualizada e vivenciada por toda a administração, juntamente com seus funcionários. Neste mesmo sentido, PINCHOT (1994) apud ABREU et al. (1999), afirma que uma organização é inteligente, bem informada e sábia, se o seu pessoal for sábio e estiver interligado, e que cada mudança requer o aprendizado de novos padrões e de novas competências.

SILVA (1998) afirma que a utilização da tecnologia da informação não deve ser tratada com um meio, mas como parte integrante de um processo de transformação das organizações. Segundo o autor, estas devem utilizar sistemas de informações gerenciais capazes de torná-las mais ágeis e eficazes, identificando as oportunidades de melhoria proporcionadas pela informática. Afirma, ainda, que as empresas devem utilizar o conhecimento como recurso estratégico, mas que o conhecimento só será alcançado através da informação, e que todos os integrantes da empresa devem ser capacitados para isto. ALENCAR \& ALBUQUERQUE (1999) afirmam que pesquisas do Gartner Group mostram que, aproximadamente $65 \%$ das empresas que conseguem alavancar seu faturamento através dos investimentos em tecnologia, têm seus sistemas de informação ligados às suas estratégias de marketing. Entretanto muitas empresas falham em alcançar os 
benefícios, oferecidos pelos sistemas de informação de marketing, porque subestimam as mudanças necessárias em tecnologia, estratégia, processos, treinamento e cultura.

De acordo com FORTULAN (1999), as implantações de novas ferramentas nas empresas devem possuir um idealizador, profissional que coordenará a implantação e que deverá a todo custo, evitar que a ferramenta enfrente falta de credibilidade. $\mathrm{O}$ autor afirma que a crise de credibilidade é a pior fase que uma implementação pode sofrer, sendo provocado por situações como:

- quando do surgimento de um erro no sistema, não existe um profissional responsável, capacitado ou mesmo interessado em solucionar o problema num prazo pré-determinado;

- quando os profissionais do nível superior não usam ou nem mesmo apoiam tal sistema;

- quando o usuário não encontra ou não conhece uma razão lógica para estar utilizando tal sistema;

- quando não se encontra um profissional na empresa para solucionar uma determinada dúvida do usuário;

- falta de um plano detalhado de implantação, estabelecendo prazos e responsabilidades, o que leva à perda de objetivo do projeto.

HELMS (1990) apud FORTULAN (1998) afirma que muitas mudanças organizacionais falham não por problemas estruturais da nova técnica, mas sim, por falta de conhecimento sobre o novo assunto, ou falta de coordenação adequada para a implantação. Assim, a comunicação é o elemento chave para uma mudança de técnica ou de comportamento, e quanto melhor for a comunicação de uma empresa, melhor será a transição de uma tecnologia ou comportamento.

MOREIRA (1998) escreve que nenhum projeto deveria ser iniciado sem que fosse bem justificado, mas na prática, nem sempre isso acontece. $\mathrm{O}$ autor presenciou projetos serem iniciados sem avaliação prévia de custo e benefício, sem justificativa baseada numa necessidade legal, ou sem estar inserido no contexto da estratégia do negócio, desviando recursos caros e importantes para projetos com benefícios discutíveis e sem relevância para a organização. No ponto de vista do autor, nenhum investimento em informática faz sentido, a menos que acrescente valor ao negócio. $\mathrm{O}$ autor é convicto de que, para uma organização alcançar a maturidade na utilização da informática, em primeiro lugar, deve haver a consciência, por parte da alta administração, da necessidade de alinhar essa tecnologia ao 
negócio, e esta consciência deve ser demonstrada por atitudes e fluir por toda a organização, de forma clara e taxativa, de forma a quebrar barreiras de resistência. A alta administração deve definir como será o negócio da empresa, quais os problemas na condução do negócio e quais os fatores críticos de sucesso do negócio. Em seguida, pode-se definir como a informática pode ajudar na condução do negócio. Somente após esta definição, deve-se focar os usuários departamentais, pois a empresa já definiu a estratégia para a informática.

TAURION (1998b) escreve que computadores são ferramentas que precisam ser acompanhadas por melhorias significativas nos processos e modelos de gestão, e cita alguns fatores críticos de sucesso a serem focados na implantação de sistemas integrados de gestão:

- visão de negócio e comprometimento da alta administração, não podendo ficar o departamento de informática isolado;

- o processo de escolha da solução deve ser bem executado, evitando influências da mídia;

- os prazos devem ser realistas e o imediatismo deve ser analisado à luz das dificuldades, pois os vendedores tem prioridades diferentes das empresas;

- a empresa deve estar comprometida com a solução, através do aculturamento e educação nos novos processos e tecnologias.

ALBERTIN \& MOURA (1995), em um estudo entre instituições bancárias nacionais sobre a área de informática, concluem que um fator crítico para a garantia de coerência com a estratégia, com as prioridades e com a estrutura organizacional, é o alinhamento estratégico da informática com a organização. Este alinhamento visa evitar uma visão parcial das necessidades da organização, com a criação da informática voltada somente para seu ambiente e a sub utilização de recursos. Outro fator crítico é o processo de priorização, que deve ser totalmente baseado no alinhamento estratégico e aplicado aos níveis de planejamento. A estrutura da informática na empresa deve facilitar a participação ativa da alta gerência e dos usuários e uma melhor comunicação entre todos os usuários, não importando o nível hierárquico. Outra conclusão dos autores, é que a função de planejamento é a principal determinante para a informática. Ela é a base para as demais atividades, sua execução contribui para o sucesso da área e para a consistência dos sistemas com a organização. Os autores afirmam que o apoio da alta gerência é um fator crítico de sucesso para o planejamento da informática, e deve:

- criar um ambiente propício à visão da informática como arma estratégica competitiva;

- garantir acesso às informações da organização, tal como seu planejamento estratégico; 
- propiciar uma visão global da organização;

- determinar as diretrizes para a informática;

- participar do processo de priorização;

- garantir os investimentos aprovados;

- facilitar a administração de mudanças no planejamento, através de solução de conflitos de recursos, estudos de viabilidades, comunicação de importância e impactos das mudanças.

TAURION (1999) afirma que é importante que usuários e desenvolvedores compreendam que uma tecnologia, como qualquer ferramenta, só será útil quando aplicada corretamente. Cabe inteiramente aos responsáveis pela informática, nessas organizações, visualizar as necessidades e serem agentes de transformações. Um executivo de informática não pode ignorar que essa talvez seja a sua principal razão de ser na empresa. Em conseqüência, o processo de seleção de um sistema deve ser bastante rigoroso, pois uma escolha errada pode resultar em um comprometimento de toda a empresa com uma visão de processos e tecnologia totalmente inadequada à cultura e operação do negócio.

GROVER et al. (1998) afirmam que, junto com a informática, o sucesso do processo de mudança também depende da estrutura organizacional, do gerenciamento do sistema e dos recursos humanos. Os autores concluem que os ganhos, na verdade, requerem mudanças não somente na tecnologia, mas nos processos, nas pessoas e nos fluxos de trabalhos. Sobre investimentos multidisciplinares, e não apenas tecnológicos, ABRAMSON (2000) apresenta dados que mostram como as empresas estão investindo em relacionamento com clientes, e compara com os dados de como elas deveriam investir, de acordo com a figuras 19 e 20:

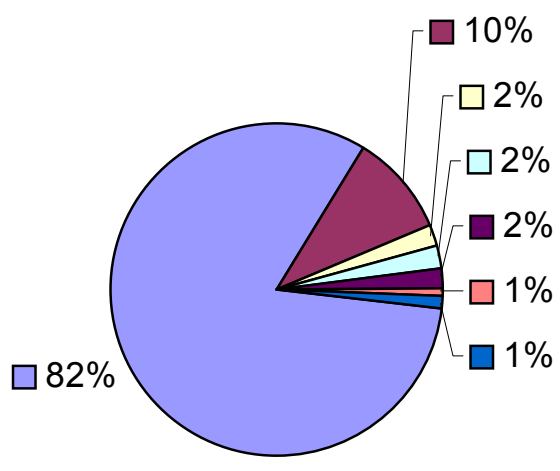

\begin{tabular}{|l|}
\hline Tecnologia \\
$\square$ Informação \\
$\square$ Pessoal \\
$\square$ Processos \\
$\square$ Organização \\
$\square$ Cultura \\
$\square$ Liderança \\
\hline
\end{tabular}

Figura 19 - Distribuição dos investimentos em relacionamento com clientes ABRAMSON (2000) 

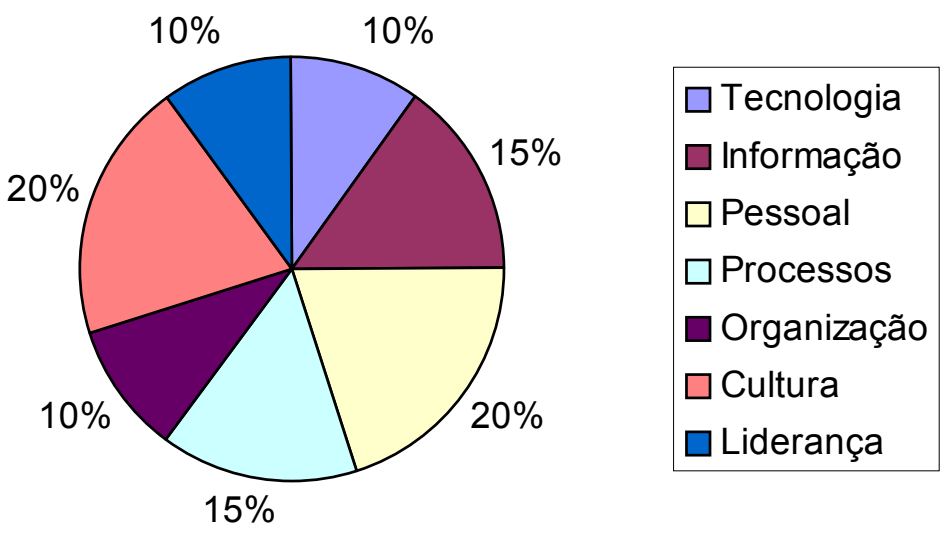

Figura 20 - Distribuição ideal dos investimentos em relacionamento com clientes - ABRAMSON (2000)

Através dos dados de ABRAMSON (2000), percebe-se que os investimentos, mesmo neste caso em relacionamento com clientes - área essencial à competitividade - o direcionamento é ainda bastante técnico, sem a devida atenção a outros aspectos importantes, como informação, processos e pessoas.

ROBBINS \& COULTER (1998) afirmam que hoje os administradores devem envolver-se diretamente com a informática na empresa, colocando-a em benefício de seu trabalho. Os administradores que não conseguirem compreender inteiramente os seus sistemas e tirar vantagem das capacidades deles, terão problemas no desempenho de seu trabalho.

BUCKHOUT et al. (1999) afirmam que, mesmo com a grande importância dos sistemas integrados de gestão, os executivos chefes não se envolvem nos processos por não terem certeza do papel a desempenhar. Diretores prestam atenção em objetivos, enquanto os técnicos concentram-se em processos, e nenhum dos lados consegue fazer as perguntas certas para o outro. Os autores afirmam que o envolvimento dos executivos chefes, em algumas questões aumenta bastante a probabilidade de êxito nestes projetos. A mais importante de suas tarefas, porém a mais negligenciada, seria resumir claramente as prioridades estratégicas da organização. Sem uma conexão estratégica, o sistema executa as funções que os técnicos acham que deve executar, o que não é necessariamente melhor para a empresa. O segredo é traduzir a visão da empresa e sua estratégia para as pessoas e depois definir exatamente como o sistema ajudará a empresa a cumprir suas prioridades. Esta etapa consome muito tempo e pode ser irritante para muitos executivos que querem dar andamento 
à implementação, mas sem ela o sistema não funciona. O autor cita a Owens Corning e a Compaq Computers, como duas bem sucedidas implementações, onde os diretores decidiram adequar o sistema às suas metas estratégicas. Outra tarefa dos executivos, segundo os autores, é envolver a organização ao nível adequado. As empresas precisam desenvolver orientações para o envolvimento dos vários níveis da organização, de forma que os membros da equipe compreendam como e em que áreas suas habilidades serão utilizadas, e, mais importante ainda, que problemas deverão resolver e quais levarão para o nível superior. Em muitos casos, estas regras não são estabelecidas, e torna-se comum que importantes decisões estratégicas sejam tomadas pela equipe técnica, a menos preparada para isto. Os autores apresentam algumas questões para avaliação da implantação dos sistemas integrados de gestão, que ajudam a avaliar as chances de sucesso:

- a diretoria compreende suficientemente bem a conexão entre implementação do sistema e a realização das metas estratégicas?

- o plano de implementação é coerente, abrangente e está vinculado a objetivos corporativos e capacidades não relacionadas com o sistema?

- o processo inclui o diálogo e a discussão sobre as difíceis escolhas que precisam ser feitas entre sistemas e outras fontes de controle?

PENZIAS (1998) afirma que é preciso haver um envolvimento real do diretor de informática com as demais áreas da empresa. Segundo o autor, este profissional não pode limitar-se a conhecer tecnologia, deve estar em pé de igualdade com os outros executivos da alta direção e fazer a interface entre a tecnologia e a administração, participando ativamente da definição da estratégia da empresa. $O$ autor conclui que sua função não é criar a estratégia, mas compreendê-la e saber suas implicações tecnológicas. PRAHALAD \& KRISHMAN (1999) afirmam que os gerentes das empresas devem identificar as características dos sistemas desejados e os fatores de qualidade para eles. Após isto, torna-se necessário treinar todos os usuários envolvidos, visando familiarizá-los com o sistema e, conseqüentemente, diminuir problemas. Os gerentes devem exigir sistemas compatíveis para minimizar os problemas de interface e sistemas que facilitem a integração de todas as áreas da empresa. LI \& YE (1999) afirmam que uma indicação crítica da integração da informática, em uma empresa, é o relacionamento entre o diretor de informática e o diretor da empresa. Para tornar a informática integrada e participante da estratégia da empresa, é necessário colocar o diretor de informática junto ao diretor da empresa, assumindo uma importante posição dentro dela. Existem fortes relacionamentos entre a orientação competitiva da informática na empresa, e a importância dada ao planejamento de informática. Ainda, segundo os autores, também existem evidências que quanto mais 
próxima e integrada estiver a informática às demais áreas da empresa, maior será a contribuição dela para a vantagem competitiva. Assim, investimentos em informática não são suficientes, e as empresas precisam integrar a informática em suas estratégias de gerenciamento. Os autores ilustram, através da figura 21 , como deveria ser o posicionamento da informática nas empresas:

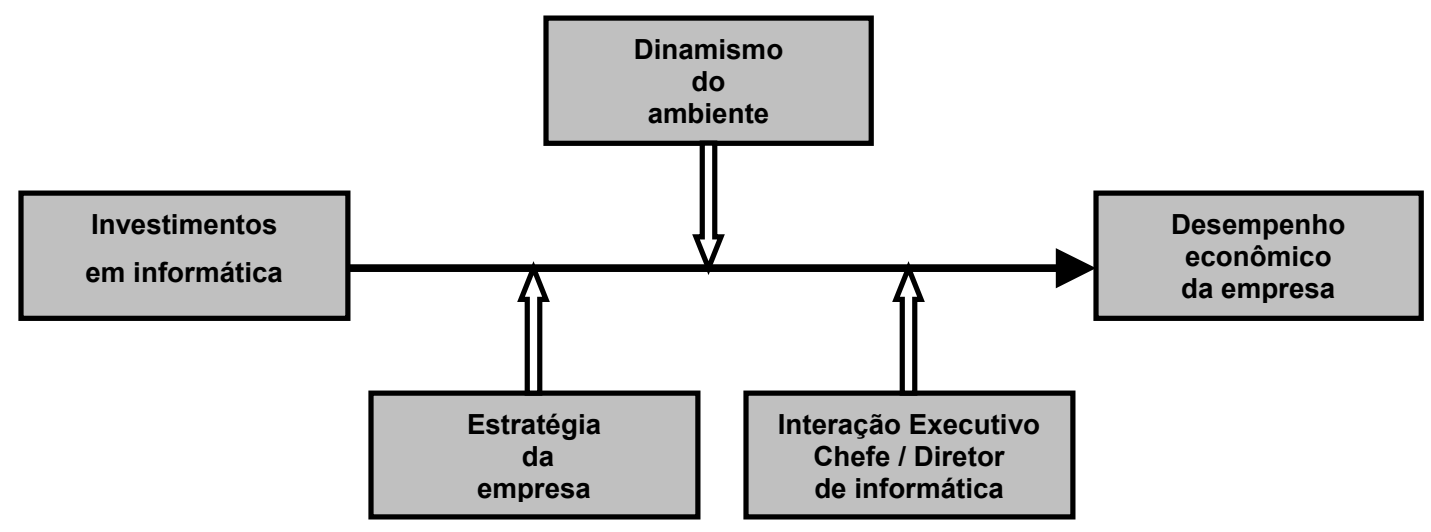

Figura 21 - Posicionamento ideal da informática nas empresas - LI \& YE (1999)

\subsection{Considerações finais do capítulo 6}

Neste capítulo, foram apresentados aspectos de aproximação entre usuários e desenvolvedores de sistema de informação, visando melhorias no desempenho da informática nas organizações. Mais especificadamente, foram apresentados os seguintes aspectos:

- o perfil do profissional de informática exigido para uma melhor interação com os usuários;

- aspectos humanos nas implementações;

- integração dos sistemas;

- envolvimento do usuário;

- administração da informática. 


\section{Capítulo 7 - Conclusões}

Concluí-se, através da bibliografia revisada, que as organizações encontram-se inseridas em um ambiente complexo e dinâmico, onde um número maior de fatores, interfere em suas atuações, de modo cada vez mais constante. Com a globalização, a abertura dos mercados, o incremento das comunicações, dos transportes, e da tecnologia, os consumidores possuem várias opções de escolha, tornando-se mais exigentes e conscientes. Neste ambiente, onde o consumidor pode escolher entre vários produtos e serviços semelhantes, as organizações esforçam-se em uma disputa agressiva para conseguir mercado. Outro aspecto a ser destacado, é que os consumidores estão mais conscientes de seus direitos, exercendo-os com maior freqüência e exigindo, além de produtos e serviços de qualidade, uma postura ética das organizações.

Neste ambiente, altamente dinâmico e competitivo, as mudanças são constantes, e as organizações devem possuir agilidade e alta percepção para atuarem nestas condições. Assim, o trabalho dos administradores ganha mais importância, pois estes são os profissionais responsáveis pela direção das organizações. Neste contexto, percebe-se que os administradores não possuem uma rotina fixa de trabalho, pois estão sempre respondendo aos mais variados estímulos temporais. Sendo a tomada de decisão, o centro do trabalho administrativo, no atual ambiente a tomada de decisão torna-se mais crítica, pois mais e mais decisões devem ser tomadas em seqüência, visando responder aos estímulos que surgem a todo momento, decisões estas quase sempre pressionadas por prazos curtos. Devido à necessidade de reagir mais rápido às mudanças, as organizações estão buscando estruturas mais flexíveis e dinâmicas, onde mais pessoas são responsáveis pelo processo decisório. Nas organizações, com estruturas tradicionais e muitos níveis hierárquicos, o tempo de resposta aos estímulos é maior, pois a comunicação entre os setores e os níveis é precária e, como somente os níveis mais elevados podem decidir, até que estes estejam conscientes dos problemas, muito tempo é perdido.

O levantamento de informações sobre a situação abordada constitui um importante fator na tomada de decisão. Somente através da informação, os administradores - decisores organizacionais - possuem condições de avaliar corretamente a situação, de desenvolver alternativas e de decidir da melhor forma possível. Sem informações de qualidade, o trabalho administrativo é grandemente prejudicado. Por outro lado, se os administradores possuírem informações de qualidade, melhores decisões serão tomadas. Entretanto, nem toda informação é de qualidade. Para ser útil ao administrador, a informação deve ser precisa, clara, completa, pontual e pertinente. A informação realmente útil, deve ser isenta de erros, 
esclarecedora, estar disponível no momento desejado e ser adequada à situação em que a decisão é tomada. Logo, somente o decisor - usuário da informação - possui condições de julgar a utilidade da informação.

Com a finalidade de melhorar a utilização da informação, as organizações investem muitos recursos em tecnologia da informação, porém, em grande parte dos casos, o retorno em competitividade e produtividade não acontece. É comum encontrarmos administradores insatisfeitos com a informática em suas organizações.

Um aspecto comum em muitas organizações, é a desconexão que existe entre os usuários e os desenvolvedores de sistemas de informação. Em muitas empresas, o relacionamento entre a área de informática e as áreas usuárias, é ruim. De um lado, os usuários acusam os profissionais de informática de possuírem comunicação precária, focarem apenas a tecnologia nos sistemas de informação, e de imporem soluções prontas. Por outro lado, os profissionais de informática acusam os usuários de mudarem constantemente suas solicitações e de não darem a devida importância à área de informática. Esta desconexão entre a área de informática e as áreas usuárias, tende a criar nas organizações, os seguintes problemas na informática:

- enfoque operacional: os sistemas de informação, em sua maioria, são desenvolvidos para atender às necessidades operacionais, elementares e de mais baixo nível hierárquico nas organizações, não atendendo, assim, às necessidades administrativas de nível mais alto, uma vez que são necessidades diferentes;

- enfoque tecnológico: a informática é empregada como um fim em si mesma, ou como a solução para todos os problemas da organização. Desta forma, os sistemas de informação são desenvolvidos focando-se apenas a tecnologia, sem ligação com o negócio da empresa, quando, seu verdadeiro valor está no uso, ou seja na disponibilização de informação;

- diversidade de sistemas: ao longo do tempo, vários sistemas incompatíveis são desenvolvidos de forma isolada nas empresas, não permitindo o fluxo de informação entre as áreas. Os levantamentos globais necessários ao trabalho administrativo, são impossíveis ou precários, dificultando sua realização.

Nas organizações que apresentam desconexão entre usuários e desenvolvedores de sistemas de informação, torna-se muito difícil aos decisores organizacionais, obterem informações de qualidade. É praticamente impossível aos profissionais de informática, proporcionarem soluções satisfatórias aos usuários, sem compreenderem exatamente suas necessidades.

Como aspectos a serem focados visando a aproximação entre as áreas, destacam-se: 
- maior envolvimento dos profissionais de informática com as áreas usuárias, evitando o isolamento da área de informática na empresa, a demasiada orientação tecnológica das soluções e visando maior entendimento das necessidades dos usuários;

- presença de um profissional multidisciplinar, que faça a ligação entre a área de informática e as áreas usuárias, ou seja, a adequação da tecnologia ao negócio da organização;

- envolvimento dos usuários, desde o início dos projetos de sistemas de informação, visando melhor captação de seus requisitos e também a melhor aceitação dos sistemas;

- planejamento da arquitetura de informática da organização, buscando sempre a integração dos novos sistemas com os antigos, de modo a evitar a incompatibilidade entre eles;

- maior envolvimento da cúpula da empresa com a área de informática, a fim de que os investimentos resultem em soluções alinhadas à estratégia de negócio;

- a informática não deve ser assumida como solução milagrosa para os problemas das organizações, mas como parte da solução, requerendo mudanças e adequações nos processos já existentes nas áreas atingidas;

- os projetos não devem ser tocados apenas pela área de informática, mas por todos os envolvidos, visando melhor adequação às necessidades e melhor aceitação dos sistemas.

A informação deve ser assumida como um recurso organizacional, obedecendo à seguinte regra: a informação fornecida deve ser igual à informação demandada. Primeiramente, os desenvolvedores de sistemas devem buscar os requisitos de seus usuários e somente após esta etapa ser bem definida, é que se deve passar às etapas seguintes no desenvolvimento do sistema. Deve haver total sintonia entre produtor e consumidor para que a solução fornecida não esteja além ou aquém das necessidades dos usuários - os clientes. Os conceitos de qualidade, que pregam a inclusão dos requisitos dos clientes desde o projeto dos produtos, deve ser seguido também no desenvolvimento de sistemas. Quando há desconexão entre usuário e desenvolvedor, ou seja, entre cliente e produtor, não há como obter, e posteriormente incluir, de forma satisfatória, os requisitos dos clientes nos projetos de sistemas, o que leva à produção de informações de má qualidade, que não atendem aos requisitos dos usuários.

Como contribuição às organizações, salientamos que estas devem adotar técnicas e metodologias que permitam a aproximação entre produtores e consumidores de sistemas de 
informação, visando a satisfatória obtenção e inclusão dos requisitos, desde o início do projeto do sistema. Esta captação dos requisitos, permite o desenvolvimento de sistemas adequados às necessidades dos clientes que, por sua vez, permitem satisfazer a regra: informação fornecida igual à informação demandada.

Como contribuição aos pesquisadores da área, este trabalho contribui para o melhor entendimento da relação entre desenvolvedores e usuários de sistemas de informação, permitindo a realização de pesquisas correlatas. Como sugestão de novas pesquisas, tem-se a investigação de procedimentos, técnicas ou metodologias que permitam o melhor relacionamento entre usuários e desenvolvedores, para a melhor captação de requisitos e conseqüentemente, disponibilização de soluções mais adequadas às necessidades dos usuários. 


\section{REFERÊNCIAS BIBLIOGRÁFICAS}

A TI muda tudo (1999) Revista HSM Management, n. 17, ano 3, p. 102, nov./dez.

ABRAMSON, G. (1999) A TI muda tudo. Revista HSM Management, n. 17, ano 3, p. 102106, nov./dez.

ABRAMSON, G. (2000) Equilíbrio de prioridades. Revista HSM Management, n. 22, ano 4, p. 142-146, maio/jun.

ABREU, A. F. et al. (1999) Acesso à informação - promovendo competitividade em P\&D com o uso da tecnologia de informação. Revista Ciência da Informação, v. 28, n. 3, p. 320-330, set./dez.

ACKOFF, R. L. (1988) Gerência em pequenas doses . Rio de Janeiro, Campus

ALBERTIN, A. L. \& MOURA, R. M. (1995) Administração de informática e seus fatores críticos de sucesso no setor bancário privado nacional. Revista de Administração de Empresas, v. 35, n. 5, p. 22-29, set./out.

ALBERTIN, A. L. (1999) Administração de informática: funções e fatores críticos de sucesso. São Paulo, Atlas

ALBRECHT, K. (1999) A terceira revolução da qualidade. Revista HSM Management, $\mathrm{n}$. 17, ano 3, p. 108-112, nov./dez.

ALENCAR, A. J. \& ALBUQUERQUE, W. (1999) Database marketing: estratégia e objetivos. Revista Developers, n. 39, ano 4, p. 60, nov.

ALMEIDA, F. C. (1995) Desvendando o uso de redes neurais em problemas de administração de empresas. Revista de Administração de Empresas, v. 35, n. 1, p. 46-55, jan./fev.

ALVIM, P. C. R. C. (1998) O papel da informação no processo de capacitação tecnológica das micro e pequenas empresas. Revista Ciência da Informação, Brasília, v. 27, n. 1, p. 28-35, jan./abr.

AMARO, A. (1999) Encarando o teste de sistemas como um projeto. Revista Developers, $\mathrm{n}$. 37, ano 4, p. 36-37, set.

AMERICANO, A. C. (1999) O valor de cada centavo. Revista Information Week. n. 15, ano 1, p. 45,8 dez.

ANGUS, J. (2000) Tradutor e intérprete de sistemas. Revista Information Week. n. 34, ano 2, p. 48-51, 16 nov.

ANTUNES, J. F. G. \& OLIVEIRA, S. R. M. (1998) Ainfo: a experiência da Embrapa na disponibilização e recuperação de informação. Revista Ciência da Informação, v. 27, n. 1, p. 82-89, jan./abr.

ASHKENAS, R. (1997) A organização do futuro. São Paulo, Futura 
BAJAJ, A. \& NIDUMOLU, S. R. (1998) A feedback model to understand system usage. Revista Information \& Management, v. 33, n. 4, p. 213-224, Mar. 25

BAKER, J. H. et al. (1998) Complex document search for decision making. Revista Information \& Management, p. 243-250, Nov. 2

BARBIERI, C. (1999) Impactos da tecnologia da informação no mundo dos negócios. Revista Developers, n. 35, ano 3, p. 28-30, jul.

BARRETO, A. A. (1998) Mudança estrutural no fluxo do conhecimento: a comunicação eletrônica. Revista Ciência da Informação, v. 27, n. 2, p. 122-127, maio/ago.

BATTAGLIA, M. G. B. (1999) A inteligência competitiva modelando o sistema de informação de clientes - Finep. Revista Ciência da Informação, v. 28, n. 2, p. 200-214, maio/ago.

BELLOQUIM, Á. (1997) A convivência entre sistemas legados e as novas tecnologias. Revista Developers, n. 13, ano 2, p. 30-32, set.

BELLOQUIM, Á. (1999a) Emprego no mundo tecnológico: está sobrando ou faltando? Revista Developers, n. 31, ano 3, p. 22-25, mar.

BELlOQUIM, Á. (1999b) A baixa produtividade e os custos de desenvolvimento. Revista Developers, n. 32, ano 3, p. 62, maio

BELLOQUIM, Á. (1999c) Porque o software não faz o que eu pedi? Revista Developers, $\mathrm{n}$. 35 , ano 3 , p. 54 , jul.

BENSAOU, M. \& EARL, M. (1998) The right mind-set for managing information technology. Harvard Business Review, v. 76, \# 5, p. 119-128, Sept./Oct.

BEUREN, I. M. (1998) Gerenciamento da Informação: um recurso estratégico no processo de gestão empresarial. São Paulo, Atlas

BIO, S.R. (1996) Sistemas de informação: um enfoque gerencial. São Paulo, Atlas

BISPO, C. A. F. \& CAZARINI, E. W. (1998). A evolução do processo decisório. In: ENCONTRO NACIONAL DE ENGENHARIA DE PRODUÇÃO - ENEGEP, XVIII. Niterói, 1998, Anais. Rio de Janeiro p.(CD-ROM)

BISPO, C. A. F. \& CAZARINI, E. W. (1999) Transformando dados em informações via data mining. Revista Developers, n. 29, ano 3, p. 36-38, jan

BOTTINO, L. (1997) Minimizando o impacto tecnológico nas empresas. Revista Developers, n. 14, ano 2, p. 48-49, out.

BRITO. M. J. et al. (1997) Tecnologia da informação e processo produtivo de gestão em uma organização cooperativa: um enfoque estratégico. Revista de Administração Contemporânea, v. 1, n. 3, p. 77-95, set./dez. 
BUCKHOUT, S. et al. (1999) Por um ERP eficaz. Revista HSM Management, n. 16, ano 3, p. 30-36, set./out.

BURN, J. M. \& SZETO, C. (2000) A comparision of the views of business and IT management on success factors for strategic alignment. Revista Information \& Management, v. 37, n. 4, p. 197-216, June

CAJADO, E. A. (1999) Gerência de projetos: conceitos, objetivos e softwares de apoio. Revista Developers, n. 37, ano 4, p. 18-19, set.

CALDAS, M. P. \& WOOD, T. J. (2000) Fads and fashions in management: the case of ERP. Revista de Administração de Empresas, São Paulo, v. 40, n. 3, p. 8-17, jul./set.

CAMARGO, R. (2000) A escalada da terceirização em TI: prós e contras. Revista Developers, n. 44, ano 4, p. 36-38, abr.

CASSARRO, A. C. (1994) Sistemas de informações para tomada de decisões. São Paulo, Pioneira

CAVALCANTI, E. P. (1995) Revolução da informação: algumas reflexões. Caderno de Pesquisa em Administração, São Paulo, v. 1, n. 1, p. 40-46, $2^{\circ}$ sem.

CERVO, A. L. \& BERVIAN, P. A. (1996) Metodologia científica. São Paulo, Makron Books

CHEN, L. et al. (2000) Measuring user satisfaction with data warehouses: an exploratory study. Revista Information \& Management, v. 37, n. 3, p. 103-110, Apr. 1

CHERMONT, G. S. (1999) O futuro da inovação tecnológica nas organizações. Revista Developers, n. 40, ano 4, p. 16-18, dez.

CHIAVENATO, I. (2000a) Administração: teoria, processo e prática. São Paulo, Makron Books

CHIAVENATO, I. (2000b) Introdução à teoria geral da administração. Rio de Janeiro, Campus

CIPULLO, F. T. (1999) A busca do equilíbrio. Revista Information Week, n. 5, a. 1, p. 24, 7 jul.

COEN, L. (1999) O CIO dos novos tempos. Revista Information Week, n. 9, ano 1, p. 40-43, 8 set.

COSTA, G. M. \& MIRANDA, J. P. B. (1999) Implantando processos de desenvolvimento de software. Revista Developers, n. 37, ano 4, p. 28-30, set.

CRIE uma arquitetura vencedora (1999) Revista Information Week, n. 15, ano 1, p. 58-61, 08 dez.

DALFOVO, O. \& GRIPA, R. (1999) Data warehouse: usando a técnica de cubo de decisão. Revista Developers, n. 32, ano 3, p. 12-17, abr. 
DALFOVO, O. et al. (1999) Sistema de informação executiva auxilia a tomada de decisão. Revista Developers, n. 40, ano 4, p. 28-32, dez.

DALLAVALLE, S. I. (2000a) Regras do Negócio, um fator chave de sucesso no processo de desenvolvimento de Sistemas de Informação. In ENCONTRO NACIONAL DE ENGENHARIA DE PRODUÇÃO, XX. São Paulo, 2000, Anais, p. (CD-ROM)

DALLAVALLE, S. I. (2000b) Estruturação do processo de desenvolvimento de software a partir da modelagem organizacional, enfatizando as regras do negócio. s.n.t. /Qualificação de Mestrado/

DAVIDOW, W. (1999) Tecnologia + marketing. Revista HSM Management, n. 13, ano 3, p. 118-123, mar./abr.

DAY, G. (1999) Como aprender sobre mercados. In: DOMINANDO administração. São Paulo, Makron Books, p. 205-209

DECISÃO inteligente (1999) Revista Information Week, n. 15, ano 1, p. 14, 08 dez.

DIA-A-DIA complicado (1999) Revista Information Week, n. 9, ano 1, p. 18, 08 set.

DIAS, D. S. (2000) Motivação e resistência ao uso da tecnologia da informação: um estudo entre gerentes. Revista de Administração Contemporânea, v.4, n. 2, p, 51-66, maio/ago.

DOLL, W. J. \& TORKZADEH, G. (1998) Developing a multidimensional measure of system-use in an organizational context. Revista Information \& Management, v. 33, n. 4, p. 171-185, Mar. 25

DRUCKER, P. F. (1981) A prática da administração de empresas, São Paulo, Pioneira

DRUCKER, P. F. (1996) Administrando em tempos de grandes mudanças. São Paulo, Pioneira

EARL, M. (1998) Deve-se terceirizar a informática? Revista HSM Management, n. 7, ano 2, p. $178-184$, jan./fev.

EARL, M. (1999) Administrando na era da informação. In: DOMINANDO administração. São Paulo, Makron Books, p. 541-545

EARL, M. \& FEENY, D. (2000) O presidente ideal para a era da informação. Revista HSM Management, n. 23, ano 4, p. 118-127, nov./dez.

E-BUSINESS confunde CEOs (2000) Revista Information Week, n. 30, ano 2, p. 14, 20 set.

ECHEVESTE, S. et al. (1997) Perfil do executivo no mercado globalizado. Revista de Administração Contemporânea, v. 3, n. 2, p. 167-186, maio/ago.

EHRLICH, P. J. (1996) Modelos quantitativos de apoio à decisão. Revista de Administração de Empresas, São Paulo, v. 36, n. 1, p. 33-41, jan./mar.

EPSTEIN, I. (1988) Teoria da informação. Editora Ática, São Paulo

ERP: mantenha-o simples (1999) Revista Information Week, n. 10, ano 1, p. 60-62, 22 set 
FARRE, T. (2001) Cronograma levado a sério. Revista Information Week, n. 39, ano 3, p. 36-38, 7 fev.

FEENY, D. F. \& WILLCOCKS, L. P. (1998) O que não terceirizar. Revista HSM Management, n. 10, ano 2, p. 132-138, set./out.

FIELD, T. (1998) O novo diretor de informática. Revista HSM Management, n. 9, ano 2, p. 46-54, jul./ago.

FIGUEIREDO, A. M. C. M. (1998) MOLAP x ROLAP: embate de tecnologias para data warehouse. Revista Developers, n. 18, ano 2, p. 24-25, fev.

FLORENZANO, V. (2000a) Onde o velho e o novo se encontram. Revista Information Week, n. 25, ano 2, p. 42-47, 5 jul.

FLORENZANO, V. (2000b) Organização bem vinda. Revista Information Week, n. 26, ano 2, p. 10-11, 19 jul.

FLORENZANO, V. (2000c) Próxima estação: futuro. Revista Information Week, n. 35, ano 2, p. 24-27, 6 dez.

FORESTI, N. (2000) Decisão pensada. Revista Information Week, n. 28, ano 2, p. 32-33, 23 ago.

FORTULAN, M. R. et al. (1999) Fatores chaves de sucesso para a implantação de novas técnicas dentro das empresas. In ENCONTRO NACIONAL DE ENGENHARIA DE PRODUÇÃO, XIX. São Paulo, 1999, Anais, p. (CD-ROM)

FULLER, M. (1998) Lições de guerra. Revista HSM Management, n. 7, ano 2, p. 92-98, jan./fev.

GARVEY, M. (1999) Reinvestir ou reestruturar? Revista Information Week, n. 10, ano 1, pp. 56-59, 22 set.

GAUSE, D. M. \& WEINBERG, G. M. (1991) Explorando requerimentos de sistemas. São Paulo, Makron, McGraw-Hill

GIL, A. C. (1991) Como elaborar projetos de pesquisa. São Paulo, Atlas

GILBERT, X. (1999) $O$ que vale é a estratégia. In: DOMINANDO administração. São Paulo, Makron Books, p. 352-355

GOLDBACH, R. (1998) Gestão corporativa: a informação a serviço da competitividade. Revista Developers, n. 20, ano 2, p. 20-21, abr.

GOMES, A. E. (1999) Métricas e estimativas de software: o início de um rallye. Revista Information Week, n. 39, ano 4, p. 50-53, nov.

GONÇALVES J. L. M. (1999) Outsourcing na TI: riscos e benefícios para as empresas. Revistas Developers, n. 36, ano 3, p. 20-21, ago. 
GONÇALVES P. S. P. (1999) Polêmica - emprego em TI: está sobrando ou faltando? Revistas Developers, n. 36, ano 3, p. 38-43, ago.

GROVER, V. et al. (1998) The influence of information technology diffusion and business process change on perceived productivity: the IS executive's perspective. Revista Information \& Management, v. 34, n. 3, p. 141-159, Oct.

GUNN, T.G. (1993) As indústrias do século 21. São Paulo, Makron Books

HAMPTON, D. R. (1990) Administração: processos administrativos. São Paulo, McGrawHill

HEHN, H. F. (1999) Peopleware: como trabalhar o fator humano nas implementações de sistemas integrados de gestão (ERP). São Paulo, Gente

HUANG, A. H. \& WINDSOR, J. C. (1998) An empirical assessment of a multimedia executive support system. Revista Information \& Management, v. 33, n. 5, p. 251-262, May 28

HUMPHREY, W. S. (2001) Tendências segundo Watts Jumphrey. In: QUALIDADE e produtividade em software. São Paulo, Makron Books, p. 51-56

HWANG, M. I. \& THORN, R. G. (1999) The effect of user engagement on system success: a meta-analytical integration of research finding. Revista Information \& Management, v. 35, n. 4, p. 229-236, Apr.

INMON, W. H. (1997) Como construir o data warehouse. São Paulo, Campus

INTEGRAÇÃO é fundamental (1999) Revista Information Week, n. 14, ano 1, p. 10-11, 17 nov.

INVESTIR para economizar (2000) Revista Information Week, n. 21, ano 2, p. 16, 03 maio

JENSEN, B. (1998) O desafio da simplicidade. Revista HSM Management, n. 9, ano 2, p. $24-$ 30 , jul./ago.

JIANG, J. J. et al. (2000) User resistance and strategies for promoting acceptance across system types. Revista Information \& Management, v. 37, n. 1, p. 25-36, Jan.

JUNTOS outra vez (1999) Revista Information Week, n. 11, ano 1, p. 28-30, 06 out.

JURAN, J. M. \& GRYNA, F. M. (1991) Controle da Qualidade. São Paulo, Makron, McGraw-Hill

KEIL, M. \& MONTEALEGRE, R. (2000) Aprendendo a desescalar. Revista HSM Management, n. 22, ano 4, p. 138-146, set./out.

KOH, C. E. \& WATSON, H. J. (1998) Data management in executive information systems. Revista Information \& Management, v. 33, n. 6, p. 301-312, June 22

KOTTER, J.P. (1982) What effective general managers really do. Harvard Business Review v. 60 , n. 6, p. 156-167, Nov./Dec. 
LACHTERMACHER, S. (1999) Em busca da tão sonhada harmonia. Revista Information Week. n. 4, ano 1, p. 32-35, 16 jun.

LEITE, J. C. (1994) Terceirização em informática. São Paulo, Makron Books

LI, M. \& YE, R. (1999) Information technology and firm performance: linking with environmental, strategic and managerial contexts. Revista Information \& Management, v. 35 , n. 1, p. 43-51, Jan.

LOZINSKY, S. (1998) Como organizar o projeto de um sistema de gestão integrado? Revista Developers, n. 20, ano 2, p. 12-16, abr.

LUCAS, H. C. (1997) Information technology for management. McGraw-Hill International Editions

LUZ, O. P. (2000) Utilizando o ERP para desbancar a concorrência. Revista Developers, $\mathrm{n}$. 41, ano 4, p. 24-26, jan.

MACEDO, T. M. B. (1999) Redes informais nas organizações: a co-gestão do conhecimento. Revista Ciência da Informação, Brasília, v. 28, n. 1, p. 94-100, jan./abr.

MAIS cedo em casa (2000) Revista Information Week. n. 26, ano 2, p. 16, 19 jul.

MANNI, L.C. \& DORSA, L.F.A. (1998) Data warehouse: gerenciando a qualidade dos dados. Revista Developers, n. 18, ano 2, p. 20, fev.

MARCHAND, D. A. (1999a) Administrando informações estratégicas. In: DOMINANDO administração. São Paulo, Makron Books, p. 341-345

MARCHAND, D. A. (1999b) Qual é a 'cultura de informação' de sua empresa?. In: DOMINANDO administração. São Paulo, Makron Books, p. 346-351

MATTOS, J. R. S. (1999) ERP: a hora do retorno. Revista Information Week, n. 13, ano 1, p. 26-27, 3 nov.

MAXIMIANO, A. C. A. (2000) Teoria geral da administração: da escola científica à competitividade na economia globalizada. São Paulo, Atlas

MAYER, R. C. (2000a) O impacto do software de gestão empresarial na informática. Revista Developers, n. 41, ano 4, p. 14-18, jan.

MAYER, R. C. (2000b) Salada de sistemas operacionais. Revista Information Week, n. 23, ano 2, p. 49, 7 jun.

MAYER, R. C. (2000c) E sua empresa, programa? Revista Information Week, n. 25, ano 2, p. 40,5 jul.

McCARTHY, J. (1994) Porque os gerentes falham e como remediar isto. São Paulo, Makron Books

McGEE, J.V. \& PRUSAK, L. (1994) Gerenciamento estratégico da informação. Rio de Janeiro, Campus 
McKENNA, R. (2000) As cinco regras do novo marketing. Revista HSM Management, $\mathrm{n}$. 22, ano 4, p. 14-22, set./out.

MELlO, A. M. V. \& BURLTON, R. (1999) Gestão de conhecimento na perspectiva de negócios. Revista Developers, n. 39, ano 4, p. 32-34, nov.

MELlO, M. C. (1999) O CMM como um guia na evolução dos processos. Revista Developers, n. 37, ano 4, p. 31-33, set.

MEYER, J. (1997) The aceptance of visual information in management. Revista Information \& Management, v. 32, n. 6, pp. 245-287, Nov. 1

MINTZBERG, H. (1986) Trabalho do executivo: o folclore e o fato. São Paulo, Nova Cultural, Coleção Harvard de Administração, n. 3, p. 5-57

MINTZBERG, H. (1995) Criando organizações eficazes: estruturas em cinco configurações. São Paulo, Atlas

MIRANDA, R. C. R. (1999) O uso da informação na formulação de ações estratégicas pelas empresas. Revista Ciência da Informação, Brasília, v. 28, n. 3, p. 284-290, set./dez.

MONTANA, P. J. \& CHARNOV, B. H. (1998) Administração. Saraiva, New York

MORAES, M. A. (1998) Informática, a angústia do usuário. Revista Developers. n. 31, ano 3, p. 66, mar.

MOREIRA, G. C. (1999) Na hora da compra. Revista Information Week, n. 15, ano 1, p. $28-$ 29,8 dez.

MOREIRA, P. (1999) Você tem o perfil que o mercado quer? Teste sua empregabilidade. Revista Developers, n. 31, ano 3, p. 10-13, mar.

MOREIRA, T. R. (1998) Uma visão resumida da justificativa e da priorização de projetos. Revista Developers, n. 17, ano 2, p. 36-38, jan.

MOREIRA, T. R. (1999) Controle de qualidade de projetos. Revista Developers, n. 38, ano 4 , p. 54 , out.

MOTTA, R. (1998) Doze idéias para reduzir custos e aumentar a eficiência. Revista Developers, n. 24, ano 2, p. 30-33, ago.

MUNRO, M. C. et al. (1997) Understanding and measuring user competence. Revista Information \& Management, v. 33, n. 1, p. 45-47, Nov. 7

NADLER, D. A. \& TUSHMAN, M. L. (2000) A organização do futuro. Revista HSM Management, n. 23, ano 4, p. 112-117, nov./dez.

NAULT, B. R. \& STOREY, V. C. (1998) Using object concepts to match artificial intelligence techniques to problem types. Revista Information \& Management, v. 34, n. 1, p. 19-31, Aug. 5 
NEHMY, R. M. Q. \& PAIM, I. (1998) A desconstrução do conceito de qualidade da informação. Revista Ciência da informação, Brasília, v. 27, n. 1, pp. 36-45, jan./abr.

NIMER, F. \& SPANDRI, L. C. (1998) Obtendo vantagem competitiva com o uso de data mining. Revista Developers, n. 18, ano 2, p. 30-31, fev.

NIMER, F. (1997) A administração de dados e o "sono de Newton". Revista Developers, n. 18, ano 2, p. 46-47, out.

NUTT, P. (1998) Entre a espada e a parede. Revista HSM Management, n. 11, ano 2, p. 112118, nov./dez.

O AMBIENTE do projeto de TI e a relação entre as áreas envolvidas (1999) Revista Developers, n. 11, ano 2, p. 10-16, set.

O LIMITE é a criatividade (2000) Revista Information Week, n. 28, ano 2, p. 18, 23 ago.

O PAPEL do CIO (2000) Revista Information Week. Edição especial E-business, p. 16-19, jan.

OLIVEIRA, D. P. R. (1996) Sistemas de Informações Gerenciais: estratégicas, táticas, operacionais. São Paulo, Atlas

OS PRAZERES e as dores da integração (2001) Revista Information Week, n. 40, ano 3, p. 63-65, $21 \mathrm{fev}$.

PALVIA, P. C. \& PALVIA, S. C. (1999) An examination of the IT satisfaction on smallbusiness users. Revista Information \& Management, v. 35, n. 3, p. 127-137, Mar. 08

PARA além da confusão (2000) Revista Information Week, n. 24, ano 2, p. 23, 21 jun.

PARTNER, T. (1999) Novos encontros. Revista Information Week, n. 15, ano 1, p. 65, 8 dez.

PASSO a passo (2000) Revista Information Week, n. 16, ano 1, p. 22, 26 jan.

PECI, A. (1999) Emergência e proliferação de redes organizacionais: marcando mudanças no mundo dos negócios. Revista de Administração Pública, n. 33, p. 7-24, nov./dez.

PENTEADO, S. (1999a) Os dez mandamentos do ROI. Revista Information Week, n. 3, ano 1, p. 26-27, 2 jun.

PENTEADO, S. (1999b) A hora do ROI. Revista Information Week, n. 4, ano 1, p. 36-40, 16 jun.

PENTEADO, S. (1999c) A corrida por novas oportunidades. Revista Information Week, $\mathrm{n}$. 11, ano 1, p. 38-43, 6 out.

PENZIAS, A. (1998) Lições de um prêmio Nobel. Revista HSM Management. n. 11, ano 2, p. $30-34$, nov./dez.

PERAZO, S. (1997) Implementando regras de negócio com Usoft. Revista Developers, n. 14, ano 2, p. 32-33, out. 
PINHEIRO, C. A. R. (1999) Data Mining: obtendo vantagens com seu data warehouse. Revista Developers, n. 35, ano 3, p. 38-40, jul.

PRAHALAD, C. K. \& KRISHMAN, M. S. (1999) The new meaning of quality in the information age. Harvard Business Review, v. 77, \# 5, p. 109-118, Sept./Oct.

PRAHALAD, C.K. (1997) A organização do futuro. São Paulo, Futura

QUALIDADE dos dados no centro das atenções (1999) Revista Information Week. n. 12, ano 1, p. 26-29, 20 out.

QUEM quer dinheiro ??? (2001) Revista Information Week. n. 37, ano 3, p. 31, 03 jan.

ROBBINS, S. \& COULTER, M. (1998) Administração. Rio de Janeiro, Prentice-Hall do Brasil

ROBBINS, S. P. (2000) Administração: mudanças e perspectivas. São Paulo, Saraiva,

ROBIC, A. R. \& SBRAGIA, R. (1996) Sucesso em projetos de informatização: Critérios de avaliação e fatores condicionantes. Caderno de Pesquisa em Administração, São Paulo, v. 1, n. 2 , p. $1-12,1^{\circ}$ sem.

SANCHES, A. M. (2000) ERP e bancos de dados: uma dupla do barulho! Revista Developers. n. 41, ano 4, pp. 22-23, jan.

SANTOS, T. (2000) Tudo ao mesmo tempo agora. Revista Information Week. n. 25, ano 2, p. $48-50,5$ jul.

SAVAGE, C. M. (1996) $5^{a}$ Geração de gerência: criando por meio do empresariamento do virtual, do dinamismo das equipes e do conhecimento colocado em rede. São Paulo, Pioneira

SAVIANI, J. R. (1998) O analista de negócios e da informação. São Paulo, Atlas

SCAGLIA, A. (1999) Às suas ordens. Revista Information Week. n. 13, ano 1, p. 40-46, 3 nov.

SCAGLIA, A. (2000) Os dinossauros rejuvenescem. Revista Information Week. n. 34, ano 2, p. 26-29, 16 nov.

SCOTT, J. E. \& KAINDL, L. (2000) Enhancing functionality in an enterprise software package. Revista Information \& Management, v. 37, n. 3, p. 111-122, Apr. 01

SEELEY, M. \& TARGETT, D. (1999) Patterns of senior executives' personal use of computers. Revista Information \& Management, v. 35, n. 6, p. 315-330, June

SEFERTZI, E. (2000) Os novos desenhos. Revista HSM Management. n. 18, ano 3, p. 74-78, jan./fev.

SEGÓRIA, A. M. (2000). Uma Estratégia para Iniciar a Melhoria do Processo de Software Contextualizada no CMM - Nivel 2. s.n.t. /Qualificação de Mestrado 
SHANKS, G. \& DARKE, P. (1999) Understanding corporate data models. Revista Information \& Management, v. 35, n. 1, p. 19-30, jan.

SILVA, A . B. (1998) Globalização, tecnologia e informação: a tríade que desafia a administração. Revista Brasileira de Administração, n. 22, ano VII, p. 10-19, jul.

SILVA, L. A. (1997) O desenvolvimento de sistemas e o método QFD. Revista Developers, n. 14 , ano 2, p. 36-39, out.

SLATER, D. (2000) Alinhamento Ford. Revista HSM Management, n. 22, ano 4, p. 24-30, set./out.

SOARES, A. (1995) Teletrabalho e comunicação em grandes CPDs. Revista de Administração de Empresas, v. 35, n. 2, p. 64-77, mar./abr.

SONDA, F. A. et al. (2000) A aplicação do QFD no desenvolvimento de software: um estudo de caso. Revista Produção, v. 10, n. 1, p. 51-75, dez.

STÁBILE, S. \& CAZARINI, E. W. (2000a) Fatores críticos de implementação de data warehouse. In ENCONTRO NACIONAL DE ENGENHARIA DE PRODUÇÃO, XX. São Paulo, 2000, Anais, Universidade de São Paulo, p. (CD-ROM)

STÁBILE, S. \& CAZARINI, E. W. (2000b) Tecnologia da informação e os níveis gerenciais das organizações. In SIMPÓSIO DE ENGENHARIA DE PRODUÇÃO, VII. Bauru, 2000, Anais, Universidade Estadual Paulista.

STAIR, R. M. (1998) Princípios de Sistemas de Informação, uma abordagem gerencial, Livros Técnicos e Científicos S/A, Rio de Janeiro

STEWART, T. A. (1998) Capital Intelectual - A nova vantagem competitiva das empresas. Rio de Janeiro, Campus

STORCK, J. \& HILL, P. A. (2000) Comunidades estratégicas. Revista HSM Management, $\mathrm{n}$. 22 , ano 4 , p. $80-88$, set./out.

SUBRAMANIAN, S. et al. (1997) Strategic planning for data warehouse. Revista Information \& Management, v. 33, n. 2, p. 99-113, Dec. 5

TAPSCOTT, D. (1999) O que esperar do mundo digital. Revista HSM Management. n. 12, ano 2, p. 132-136, jan./fev.

TAURION, C. (1998a) O Data warehouse será útil para sua organização? Revista Developers. n. 18, ano 2, p. 26-27, fev.

TAURION, C. (1998b) Sistemas de gestão empresarial: a solução final? Revista Developers. n. 20, ano 2, p. 10-11, abr.

TAURION, C. (1999) A frente aberta pelo middle market para os desenvolvedores. Revista Developers. n. 29, ano 3, p. 10-11, jan. 
TAURION, C. (2000) A linguagem dos negócios. Revista Gestão Empresarial. p.18-21, mar.

TEIXEIRA, J. (1999) Transformando dados corporativos em vantagem competitiva. Revista Developers, n. 38, ano 4, p. 16-17, out.

TOMINORI, S. M. A. W. (1999) A inteligência competitiva e a área de informação tecnológica no Instituto de Pesquisas Tecnológicas do Estado de São Paulo S.A. Revista Ciência da Informação, Brasília, v. 28, n. 1, p. 89-93, jan.

TREPPER, C. (2000) Do caos à ordem. Revista Information Week. n. 30, ano 2, p. 36-37, 20 set.

UM CAMINHO sem volta (2000) Revista Information Week. Edição especial E-Business, p. $8-13$, jan.

UM PRONTO socorro enxuto (2000) Revista Information Week. n. 28, ano 2, p. 16, 23 ago.

UMA NOVA abordagem para integração (2000) Revista Information Week. n. 32, ano 2, p. 36-39, 18 out.

VALENTE, F. F. R. (1999) A implantação do CMM de qualidade de software na Xerox. Revista Developers. n. 35, ano 3, p. 42-44, jul.

VAZ, R. (1999) Discutindo sistemas de informação nas organizações. Revista Developers. $n$. 35, ano 3, p. 20-23, jul.

VECCHIA, M. (1998) A infra-estrutura na construção de um data warehouse. Revista Developers. n. 19, ano 2, p. 46-47, mar.

VILAROUCA, J. (1999) Para sobreviver como CIO. Revista Information Week. n. 15, ano 1, p. $46-48,8$ dez.

WAH, L. (2000) Muito além do modismo. Revista HSM Management, n. 22, ano 4, p. 52-62, set./out.

WANCELOTTI, L. F. \& LOMBOGLIA, A. (2000) Onde nasce a informação. Revista Information Week. Edição especial E-business, p. 46-47, jan.

WANDERLEY, A. V. M. (1999) Um instrumento de macropolítica de informação. Concepção de um sistema de inteligência de negócios para gestão de investimentos em engenharia. Revista Ciência da Informação, v. 28, n. 2, p. 190-199, maio/ago.

WANG, C. B. (1995) O novo papel do executivo de informática. São Paulo, Makron Books

WELCH, J. (2000) A administração depois da Internet. Revista HSM Management, n. 22, ano 4 , p. 6-12, set./out.

WELLS, J. D. et al. (1999) Managing information technology (IT) for one-to-one customer interaction. Revista Information \& Management, v. 35, n. 1, p. 53-62, Jan. 
WHITAKER, K. (1994) Gerenciando maníacos por software. Rio de Janeiro, Infobook XAVIER, M. P .T. \& GOMES, S. B. (1999) A informação como vantagem da empresa competitiva. Revista Developers. n. 30, ano 3, p. 26-29, fev.

ZUCCHI, A. L. (1999) Análise do sistema de informação contábil: relações com o ambiente empresarial e utilização de tecnologia da informação. Revista de Contabilidade do CRC - SP. n. 10, Ano IV, p. 42-53, dez. 